GABRIELA PLACONÁ DINIZ

\begin{abstract}
AVALIAÇÃO DA CONTRIBUIÇÃO DO RECEPTOR AT1 DE ANGIOTENSINA II E DO PAPEL DA VIA DE SINALIZAÇÃO AKT/GSK3-ß/mTOR NO PROCESSO DE HIPERTROFIA DO CARDIOMIÓCITO INDUZIDO PELO HORMÔNIO TIROIDEANO
\end{abstract}

Tese apresentada ao Programa de PósGraduação em Ciências Morfofuncionais do Departamento de Anatomia do Instituto de Ciências Biomédicas da Universidade de São Paulo, para a obtenção do Título de Doutor em Ciências.

São Paulo 
GABRIELA PLACONÁ DINIZ

AVALIAÇÃO DA CONTRIBUIÇÃO DO RECEPTOR AT1 DE ANGIOTENSINA II E DO PAPEL DA VIA DE SINALIZAÇÃO AKT/GSK3-ß/mTOR NO PROCESSO DE HIPERTROFIA DO CARDIOMIÓCITO INDUZIDO PELO HORMÔNIO TIROIDEANO

Tese apresentada ao Programa de PósGraduação em Ciências Morfofuncionais do Departamento de Anatomia do Instituto de Ciências Biomédicas da Universidade de São Paulo, para a obtenção do Título de Doutor em Ciências.

Área de Concentração:

Ciências Morfofuncionais.

Orientadora:

Profa Dra Maria Luiza Morais Barreto de Chaves.

São Paulo 
DADOS DE CATALOGAÇÃO NA PUBLICAÇÃO (CIP)

Serviço de Biblioteca e Informação Biomédica do

Instituto de Ciências Biomédicas da Universidade de São Paulo

(C) reprodução total

Diniz, Gabriela Placoná.

Avaliação da contribuição do receptor AT1 de Angiotensina II e do papel da via de sinalização Akt/GSK3-ß/mTOR no processo de hipertrofia do cardiomiócito induzido pelo hormônio tiroideano / Gabriela Placoná Diniz. -- São Paulo, 2009.

Orientador: Maria Luiza Morais Barreto de Chaves.

Tese (Doutorado) - Universidade de São Paulo. Instituto de Ciências Biomédicas. Departamento de Anatomia. Área de concentração:

Ciências Morfofuncionais. Linha de pesquisa: Estudo morfofuncional do sistema renina-angiotensina.

Versão do título para o inglês: Angiotensin type 1 receptor mediates Thyroid Hormone-induced cardiomyocyte hypertrophy through the Akt/GSK-3ß/mTOR signaling pathway.

Descritores: 1. Hormônios tiroideanos 2. Receptores de angiotensina 3. Cardiomiócitos 4. Sistema renina-angiotensina 5. Hipertrofia cardíaca 6. RNA de interferência I. Barreto-Chaves, Maria Luiza Morais II. Universidade de São Paulo. Instituto de Ciências Biomédicas. Programa de Pós-Graduação em Ciências Morfofuncionais III. Título. 
Candidato(a): $\quad$ Gabriela Placoná Diniz.

Título da Tese: $\quad$ Avaliação da contribuição do receptor AT1 de Angiotensina Il e do papel da via de sinalização Akt/GSK3-ß/mTOR no processo de hipertrofia do cardiomiócito induzido pelo hormônio tiroideano.

Orientador(a):

Maria Luiza Morais Barreto de Chaves.

A Comissão Julgadora dos trabalhos de Defesa da Tese de Doutorado, em sessão pública realizada a .................., considerou

\section{( ) Aprovado(a) ( ) Reprovado(a)}

\begin{tabular}{|c|c|}
\hline Examinador(a): & 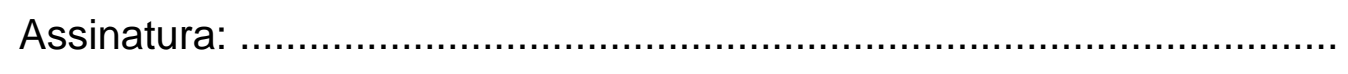 \\
\hline & Nome: \\
\hline & Instituição: ....................... \\
\hline Examinador(a): & Assinatura: ..... \\
\hline & Nome: ................ \\
\hline & Instituição: .......... \\
\hline Examinador(a): & Assinatura: ...... \\
\hline & Nome: ................ \\
\hline & Instituição: ........... \\
\hline Examinador(a): & Assinatura: .. \\
\hline & Nome: ........................... \\
\hline & 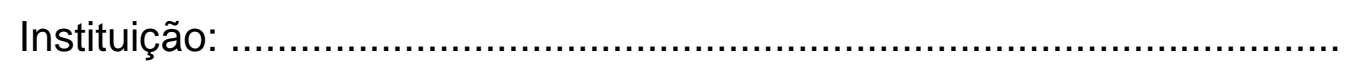 \\
\hline Presidente: & Assinatura: . \\
\hline & Nome: ................... \\
\hline & 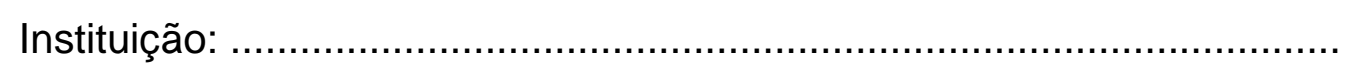 \\
\hline
\end{tabular}


UNIVERSIDADE DE SĂO PAULO

INSTITUTO DE CIÊNCIAS BIOMÉDICAS

Cltade Universitaris -Armarnos de Salles Otiveira"

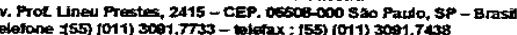

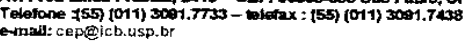

\section{Certificado}

Certificamos que o protocolo registrado sob $\mathrm{II}^{\circ} 114$ nas fls. 9 do livro 2 para uso de animais em experimentaçāo, sob a responsabilidade da Profa. Dra. Maria Luiza Morais Barreto de Chaves, Coordenadora da Linha de Pesquisa "Papel do sistema renina-angiotensina na hipertrofia cardiaca e/ou renal induzida pelos hormônios tiroideanos" do qual participou(aram) o(s) aluno(s): Marcela Sorelli Carneiro Ramos, Luana dos Anjos Ramos, Maria Alicia C.Sepúlveda, Gabriela Placonã Diniz, Erenaldo Júnior, Tattiana Pubäll, está de acordo com os Principios Éticos de Experimentaçāo Animal adotado pelo Colégio Brasileiro de Experimentação Animal (COBEA) e foi aprovado pela COMSSĀO DE ETICA EM EXPERIMENTAÇĂO ANIMAL (CEEA) em 16.12.2004.

São Paulo, 20 de dezembro de 2004.

Profa. Dra. Marilia C. Leite Selaender Coordenadora da CEEA

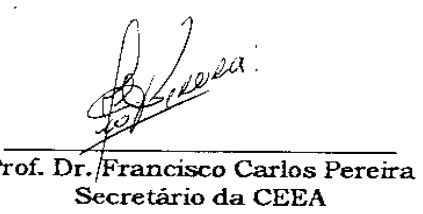


Aos meus queridos pais, Leda e Pedro. Vocês são a razão dos meus sonhos tornarem-se realidade!

Aos meus irmãos, Patricia e Daniel, pelo amor e carinho de sempre.

Ao Marcos, pelo amor, companheirismo, força e por torcer tanto por mim!

Muito obrigada por tudo! Vocês são os amores da minha vida! 


\section{AGRADECIMENTOS}

Aos meus pais, Leda e Pedro, pelo imensurável amor e carinho que sempre me concederam! Por serem um exemplo de bom caráter, dedicação e perseverança, e por me ensinarem que é através do nosso trabalho que conquistamos o mundo. Obrigada por sempre estarem ao meu lado, por me darem força nos momentos difíceis e por me ensinarem coisas novas todos os dias. Não existem palavras ou gestos capazes de explicar a profunda gratidão e admiração que tenho por vocês! É graças a vocês que cheguei até aqui!

Aos meus irmãos, Patricia e Daniel, e ao Marcos, por todos os nossos momentos, pelo amor inigualável, pelo carinho e por nunca me deixarem desanimar!

À minha orientadora, "mãe científica" e grande amiga, $\operatorname{Prof}^{\mathrm{a}} \operatorname{Dr}^{\mathrm{a}}$ Maria Luiza Morais Barreto de Chaves, o meu eterno agradecimento pelas inúmeras oportunidades! Muito obrigada pelos ensinamentos, conselhos, paciência, ombro amigo e amizade! É imensurável a admiração e o carinho que tenho por você! É a você que devo as conquistas obtidas até hoje e as que ainda irão surgir, se Deus quiser! Como você mesmo costuma dizer, "Somos cúmplices"!

À minha parceira de muito trabalho e querida amiga, $\operatorname{Prof}^{\mathrm{a}} \operatorname{Dr}^{\mathrm{a}}$ Marcela Sorelli Carneiro Ramos, pela força, ajuda, carinho e amizade de sempre. Muito obrigada por tudo!

A todos os queridos amigos do laboratório, Ana Paula, Ana Cláudia, Caroline Antunes, Caroline Shibata, Dayane, Félix, Lincoln, Marcelo, Maria Alicia, Micheli e Priscilla. Obrigada por todos os momentos. É imenso o carinho que tenho por todos vocês!

À Prof ${ }^{a} \operatorname{Dr}^{\mathrm{a}}$ Maria Tereza Nunes e a seus alunos, especialmente à Erika e ao Fran, por toda ajuda e atenção que sempre me concederam. Muito obrigada!

À Prof ${ }^{\mathrm{a}}$ Dr $^{\mathrm{a}}$ Mayana Zatz e a seus alunos, Natássia e Eder, pelo auxílio nos experimentos de citometria de fluxo. Muito obrigada pela ajuda que sempre me concederam. 
À Prof ${ }^{\mathrm{a}} \operatorname{Dr}^{\mathrm{a}}$ Dulce E. Casarini do Departamento de Fisiologia da Universidade Federal de São Paulo, pelo auxílio nos experimentos de dosagens de Angiotensina, por HPLC, no meio de cultura.

À Prof ${ }^{a} \operatorname{Dr}^{\mathrm{a}}$ Maria Helena Catelli de Carvalho e à Rosângela por terem cedido a utilização do termociclador para os experimentos iniciais de PCR em Tempo Real.

À Prof $^{\mathrm{a}} \operatorname{Dr}^{\mathrm{a}}$ Edna Teruko Kimura, pelo incentivo quanto ao uso da técnica de RNA de interferência nas culturas primárias de cardiomiócitos.

A todos os professores, alunos e funcionários do Departamento de Anatomia, que contribuíram de alguma forma para a realização deste trabalho.

Aos funcionários do Biotério do Instituto Butantan, pela gentileza e atenção de sempre.

Às instituições de fomento, CAPES, CNPq, e especialmente à FAPESP, por terem nos concedido auxílio financeiro, o qual permitiu o desenvolvimento deste estudo e de diversos projetos do nosso laboratório, e foram fundamentais para a minha formação acadêmica e científica. 
"A insatisfação é um elemento indispensável para quem, mais do que repetir, deseja criar, inovar, refazer, modificar, aperfeiçoar".

Mario Sergio Cortella. 


\section{RESUMO}

DINIZ, G. P. Avaliação da contribuição do receptor AT1 de Angiotensina II e do papel da via de sinalização Akt/GSK3- $\beta$ /mTOR no processo de hipertrofia do cardiomiócito induzido pelo hormônio tiroideano. 2009. Tese - Instituto de Ciências Biomédicas, Universidade de São Paulo, São Paulo, 2009.

Diversos estudos evidenciaram que o Sistema Renina Angiotensina participa da hipertrofia cardíaca induzida pelo hormônio tiroideano. Entretanto, se o receptor AT1 de Angiotensina II é crítico para o desenvolvimento da hipertrofia dos cardiomiócitos promovida pelo $\mathrm{T}_{3}$, bem como se os mecanismos intracelulares deflagrados por este receptor são capazes de contribuir para este modelo de hipertrofia ainda não são conhecidos. Para isso, utilizou-se um RNA de interferência (RNAi) específico para o receptor AT1, ou um bloqueador farmacológico, para avaliar o papel deste receptor em culturas primárias de cardiomiócitos submetidas ao tratamento com $\mathrm{T}_{3}$. Os cardiomiócitos transfectados com RNAi para AT1 apresentaram redução da expressão gênica e protéica deste receptor. O silenciamento do receptor AT1, ou o bloqueio farmacológico deste receptor, preveniu totalmente a hipertrofia dos cardiomiócitos induzida pelo $\mathrm{T}_{3}$, evidenciado pela redução da expressão gênica do fator natriurético atrial e $\alpha$-actina esquelética e pela redução da síntese protéica. Os cardiomiócitos tratados com $\mathrm{T}_{3}$ demonstraram uma rápida ativação da via de sinalização Akt/GSK-3 $3 / \mathrm{mTOR}$, a qual foi completamente inibida pelo uso de inibidores da PI3K. Além disso, os resultados deste estudo mostram que o receptor AT1 atua como um mediador da ativação da via Akt/GSK-3 $\beta /$ mTOR induzida pelo $T_{3}$, uma vez que o silenciamento do receptor AT1, ou o bloqueio farmacológico deste receptor, atenuou ou preveniu totalmente a ativação desta via de sinalização. Ainda, os níveis de Angiotensina I e Angiotensina II foram aumentados no meio de cultura das células tratadas com $\mathrm{T}_{3}$. Além disso, a expressão de Angiotensina I/II (Ang I/II) no lisado celular e a expressão do receptor AT1 foram rapidamente aumentados pelo $\mathrm{T}_{3}$. Esses dados demonstram pela primeira vez que o receptor AT1 é um mediador crítico tanto para a hipertrofia dos cardiomiócitos induzida pelo $\mathrm{T}_{3}$, bem como para a ativação da via da Akt/GSK-3//mTOR. Ainda, os resultados presentes neste estudo indicam um novo mecanismo pelo qual o $\mathrm{T}_{3}$ promove hipertrofia dos cardiomiócitos, sugerindo que a via Ang II-AT $\mathrm{R}_{1}$-Akt/GSK-3 $\beta /$ mTOR corresponde a um potencial mediador dos $\mathrm{e}^{f}$ tróficos exercidos pelo $\mathrm{T}_{3}$ nessas células.

Palavras-chave: Receptor AT1 de Angiotensina II; Hormônio tiroideano; Cardiomiócito; Via de sinalização Akt/GSK-3 $\beta / m$ TOR; Hipertrofia. 


\begin{abstract}
DINIZ, G. P. Angiotensin type 1 receptor mediates Thyroid Hormone-induced cardiomyocyte hypertrophy through the Akt/GSK-3ß/mTOR signaling pathway. 2009. Thesis - Institute of Biomedical Sciences, University of São Paulo, São Paulo, Brazil.
\end{abstract}

Several studies have implicated the renin angiotensin system in the cardiac hypertrophy induced by thyroid hormone. However, whether Angiotensin type 1 receptor $\left(\mathrm{AT}_{1} \mathrm{R}\right)$ is critically required to the development of $\mathrm{T}_{3}$-induced cardiomyocyte hypertrophy, as well as whether the intracellular mechanisms that are triggered by $\mathrm{AT}_{1} \mathrm{R}$ are able to contribute to this hypertrophy model is unknown. To address these questions, we employed a selective small interfering RNA (siRNA) or an $\mathrm{AT}_{1} \mathrm{R}$ blocker to evaluate the specific role of this receptor in primary cultures of neonatal cardiomyocytes submitted to $\mathrm{T}_{3}$ treatment. The cardiomyocytes transfected with the $\mathrm{AT}_{1} \mathrm{R}$ siRNA presented reduced mRNA and protein expression of $\mathrm{AT}_{1} \mathrm{R}$. The $\mathrm{AT}_{1} \mathrm{R}$ silencing and the $\mathrm{AT}_{1} \mathrm{R}$ blockade totally prevented the $\mathrm{T}_{3}$-induced cardiomyocyte hypertrophy, as evidenced by lower mRNA expression of atrial natriuretic factor and $\alpha$ skeletal-actin, as well as by reduction in protein synthesis. The cardiomyocytes treated with $\mathrm{T}_{3}$ demonstrated a rapid activation of Akt/GSK-3 $\beta /$ mTOR signaling pathway, which was completely inhibited by the use of PI3K inhibitors. In addition, the results of this study show that the $A_{1} R$ mediated the $T_{3}$-induced activation of Akt/GSK-3 $3 / \mathrm{mTOR}$ signaling pathway, since the $\mathrm{AT}_{1} \mathrm{R}$ silencing and the $\mathrm{AT}_{1} \mathrm{R}$ blockade attenuated or totally prevented the activation of this signaling pathway. We also reported that local Angiotensin I/II (Ang I/II) levels and the $\mathrm{AT}_{1} \mathrm{R}$ expression were rapidly increased by $T_{3}$ treatment. These data demonstrate for the first time that the $A_{1} R$ is a critical mediator to the $\mathrm{T}_{3}$-induced cardiomyocyte hypertrophy, as well as to the activation of Akt/GSK$3 \beta / \mathrm{mTOR}$ signaling pathway. In addition, the results present in this study suggest a new insight in the mechanism of $\mathrm{T}_{3}$-induced cardiomyocyte hypertrophy, indicating that the Ang I/II-AT $\mathrm{R}$ Akt/GSK-3 $\beta /$ mTOR pathway corresponds to a potential mediator of the trophic effect exerted by $\mathrm{T}_{3}$ in cardiomyocytes.

Key words: Angiotensin II type 1 receptor; Thyroid hormone; Cardiomyocyte; Akt/GSK$3 \beta /$ mTOR signaling pathway; Hypertrophy. 


\section{LISTA DE FIGURAS}

Figura 1. Esquema representativo dos principais componentes do SRA...................................21

Figura 2. Esquema representativo de algumas das ações genômicas e não genômicas exercidas pelo $\mathrm{T}_{3}$ em cardiomiócitos.

Figura 3. Esquema representativo de algumas das proteínas da via PI3K/Akt/GSK3- $\beta / m T O R$ ativadas pela Ang II através do receptor AT1..... .28

Figura 4. Análise das culturas primárias de cardiomiócitos através de imunocitoquímica para tropomiosina sarcomérica e para vimentina em microscópio de fluorescência .45

Figura 5. Análise da eficiência de transfecção das culturas primárias de cardiomiócitos com RNAi controle positivo em microscopia confocal ou citometria de fluxo. .46

Figura 6. Análise da expressão gênica do receptor AT1 em cardiomiócitos transfectados com RNAi para AT1 com diferentes conteúdos de G/C, avaliada por PCR em Tempo Real......

Figura 7. Análise da expressão protéica do receptor AT1 em cardiomiócitos transfectados com RNAi para AT1 com diferentes conteúdos de G/C, avaliada por Western Blotting.

Figura 8. Análise da expressão gênica e protéica do receptor AT1 em cardiomiócitos transfectados com RNAi para AT1, avaliada respectivamente por PCR em Tempo Real e por Western Blotting.

Figura 9. Análise da expressão protéica do receptor AT2 em culturas primárias de cardiomiócitos transfectadas com RNAi para AT1, avaliada por Western Blotting. .49

Figura 10. Análise da expressão protéica do receptor AT1 em culturas primárias de cardiomiócitos transfectadas com RNAi controle negativo por Western Blotting.. .50

Figura 11. Análise da expressão gênica de ANF e $\alpha$-actina esquelética, avaliada por PCR em Tempo Real e ensaio de incorporação de leucina triciada. .51

Figura 12. Análise dos níveis de Akt fosforilada na $\operatorname{Ser}^{473}$ e na $\mathrm{Thr}^{308}$, Akt total e razão Akt fosforilada na $\mathrm{Ser}^{473}$ e na $\mathrm{Thr}^{308} /$ Akt total avaliada por Western Blotting. .53

Figura 13. Análise dos níveis de GSK3- $\beta$ fosforilada na Ser $^{9}$, GSK3- $\beta$ total e razão GSK3- $\beta$ fosforilada na $\operatorname{Ser}^{9} / \mathrm{GSK} 3-\beta$ total avaliada por Western Blotting. .55

Figura 14. Análise dos níveis de mTOR fosforilada na $\operatorname{Ser}^{2448}$, mTOR total e razão mTOR fosforilada na $\mathrm{Ser}^{2448} / \mathrm{mTOR}$ total avaliada por Western Blotting. .57 
Figura 15. Avaliação dos níveis de Akt fosforilada na $\operatorname{Ser}^{473}$, Akt total e razão Akt fosforilada na $\mathrm{Ser}^{473} /$ Akt total, através da técnica de Western Blotting.

Figura 16. Avaliação dos níveis de GSK3- $\beta$ fosforilada na Ser ${ }^{9}$, GSK3- $\beta$ total e razão dos níveis de GSK3- $\beta$ fosforilada na Ser'/GSK3- $\beta$ total, através da técnica de Western Blotting.

Figura 17. Avaliação dos níveis de mTOR fosforilada na $\operatorname{Ser}^{2448}$, mTOR total e razão dos níveis de mTOR fosforilada na $\mathrm{Ser}^{2448} / \mathrm{mTOR}$ total, realizada por Western Blotting. .61

Figura 18. Análise dos níveis de Ang I e Ang II no meio de cultura por HPLC e avaliação da expressão protéica de Ang I/II por Western Blotting..... .62

Figura 19. Avaliação da expressão gênica e protéica do receptor AT1, analisada respectivamente por PCR em Tempo Real e por Western Blotting .63

Figura 20. Modelo proposto para a participação do receptor AT1 na hipertrofia do cardiomiócito induzida pelo $\mathrm{T}_{3}$, bem como na ativação da via da Akt. 


\section{LISTA DE TABELAS}

Tabela 1. Sequências dos primers utilizados para a análise da expressão gênica por PCR em

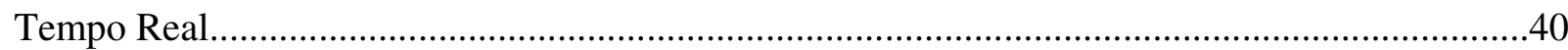

Tabela 2. Lista de anticorpos primários utilizados para a análise de expressão protéica por

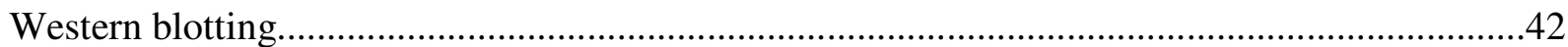




\section{LISTA DE SÍMBOLOS}

\section{Bases nitrogenadas dos nucleotídeos}

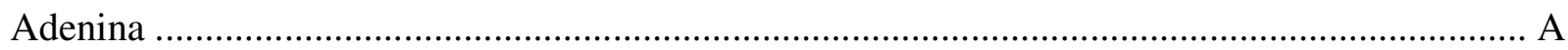

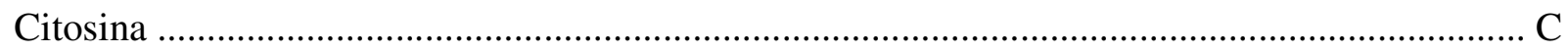

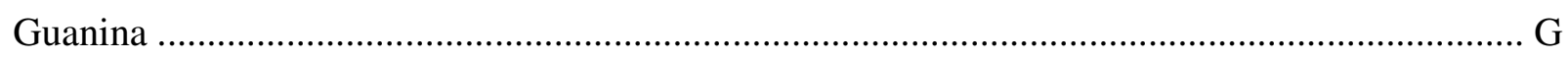

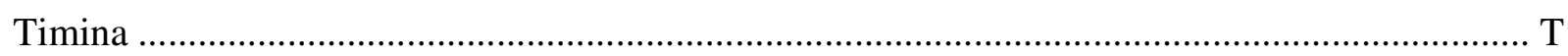

\section{Aminoácidos}

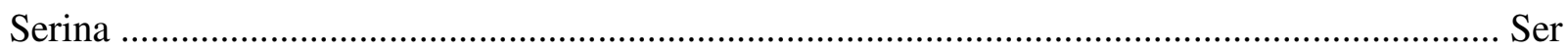

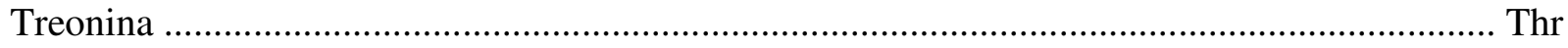

\section{Símbolos}

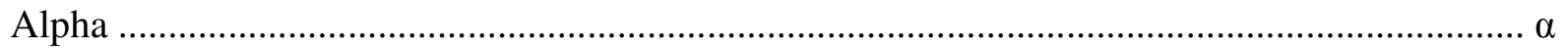

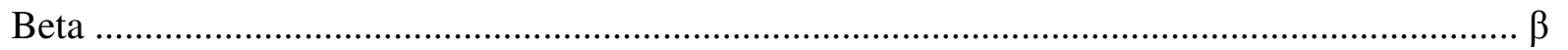

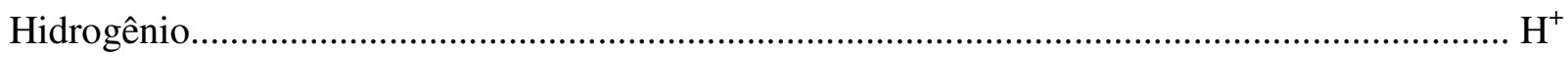




\section{LISTA DE ABREVIATURAS}

Ang I- Angiotensina I

Ang II- Angiotensina II

Ang I/II- Angiotensina I/II

AT1- receptor de Angiotensina II tipo 1

AT2- receptor de Angiotensina II tipo 2

cDNA- DNA complementar

CT- do inglês treshold cycle

DAPI- do inglês 4',6-diamidino-2-phenylindole

DMEM- do inglês Dulbecco's Modified Eagle's Medium

DNA- ácido desoxirribonucléico

ECA- Enzima conversora de Angiotensina

HS- do inglês horse serum

HT- hormônio tiroideano

NCS- do inglês newborn calf serum

PBS- tampão salina fosfato

PCR- reação em cadeia da polimerase

RNA- ácido ribonucléico

RNAi- RNA de interferência

RNAm- RNA mensageiro

RT- reação de transcrição reversa

SRA- Sistema Renina Angiotensina

$\mathbf{T}_{\mathbf{3}^{-}}$triiodotironina

TGF- $\boldsymbol{\beta} 1$ - fator transformante de crescimento $\beta-1$ 


\section{SUMÁRIO}

\section{INTRODUÇÃO}

1.1 Hipertrofia Cardíaca.

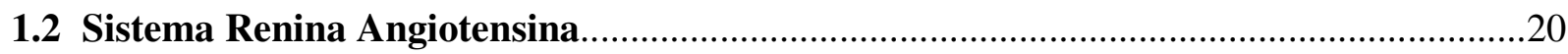

1.3 Sinalização intracelular deflagrada pela ativação do receptor AT1 .............................24

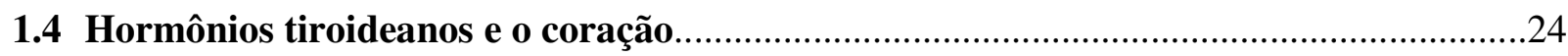

1.5 Via de sinalização PI3K/Akt/GSK3- $\beta$ /mTOR e Hipertrofia Cardíaca..............................27

1.6 Sistema Renina Angiotensina e Hormônios Tiroideanos..................................................29

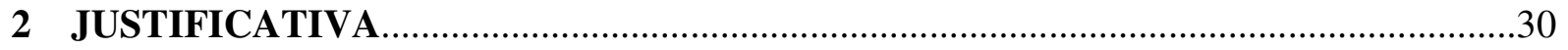

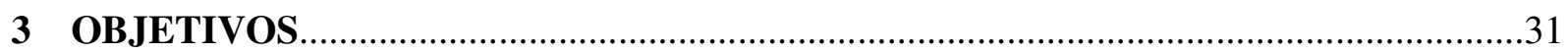

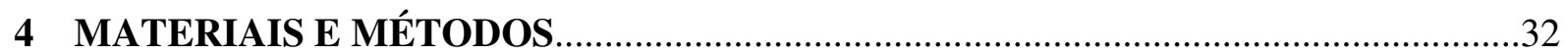

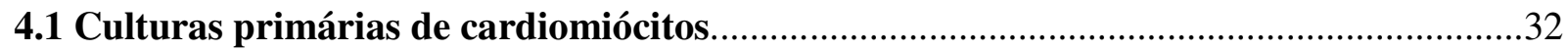

4.2 Caracterização das culturas primárias de cardiomiócitos.................................................32

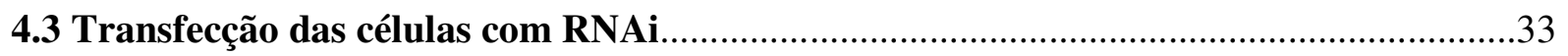

4.3.1 Avaliação da eficiência de transfecção - Utilização de um RNAi controle positivo.......34

4.3.2 Avaliação do efeito da transfecção na expressão do receptor AT1 - Utilização de um RNAi controle negativo (Scramble RNAi).

4.3.3 Avaliação da eficiência do silenciamento do receptor AT1 - Utilização de RNAi específico.

4.3.4 Avaliação da contribuição do receptor AT1 para a hipertrofia dos cardiomiócitos induzida pelo $\mathbf{T}_{3}$

4.3.5 Avaliação da contribuição do receptor AT1 para a ativação da via Akt/GSK3$\beta /$ mTOR promovida pelo $\mathrm{T}_{3}$

4.3.6 Análise da participação da PI3K para a ativação da via Akt/GSK3- $\beta$ /mTOR induzida pelo $\mathbf{T}_{3}$

4.3.7 Avaliação do efeito do $T_{3}$ nos níveis de Ang I/II e na expressão gênica e protéica do receptor AT1.

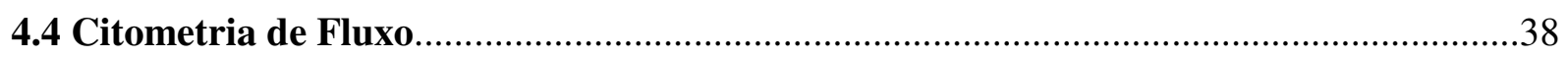

4.5 Análise da Expressão Gênica - PCR em Tempo Real....................................................39 


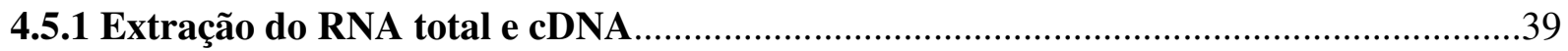

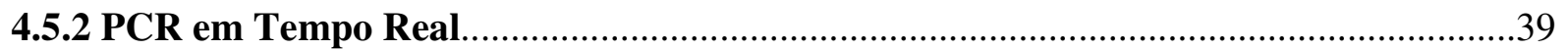

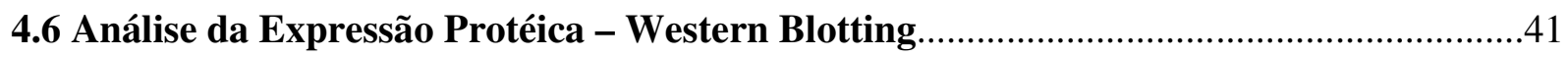

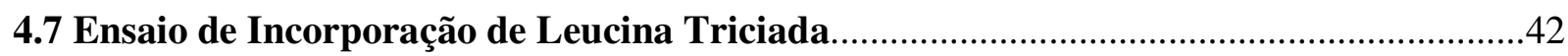

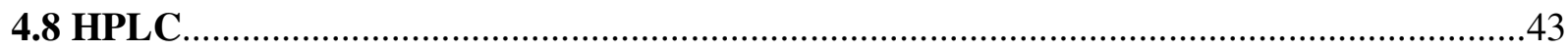

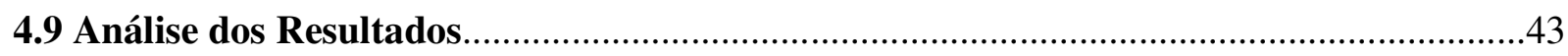

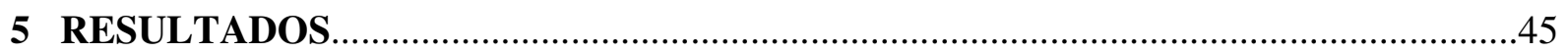

5.1 Caracterização das culturas primárias de cardiomiócitos por imunocitoquímica............45

5.2 Avaliação da eficiência de transfecção das culturas primárias de cardiomiócitos -

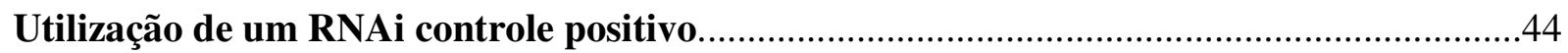

5.3 Avaliação da eficiência do silenciamento do receptor AT1- Utilização de RNAi para receptor AT1

5.4 Avaliação do efeito da transfecção na expressão do receptor AT1 - Utilização de um RNAi controle negativo (Scramble RNAi). .50

5.5 Avaliação da contribuição do receptor AT1 para a hipertrofia cardiomiocítica induzida pelo $\mathbf{T}_{3}$

5.6 Avaliação da participação do receptor AT1 na ativação da via de sinalização Akt/GSK3$\beta / m$ TOR induzida pelo $T_{3}$

5.7 Avaliação da participação da PI3K para a ativação da via de sinalização Akt/GSK3$\beta /$ mTOR promovida pelo $T_{3}$

5.8 Análise dos níveis de Ang I/II e da expressão do receptor AT1 em culturas de

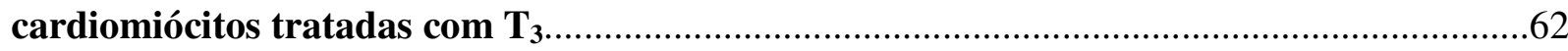

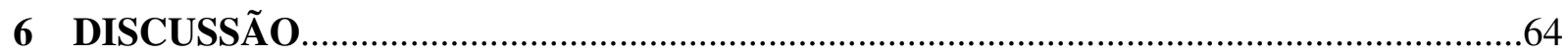

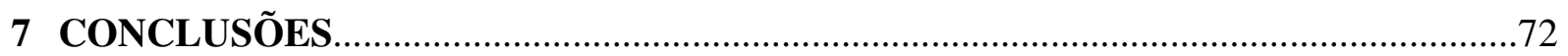

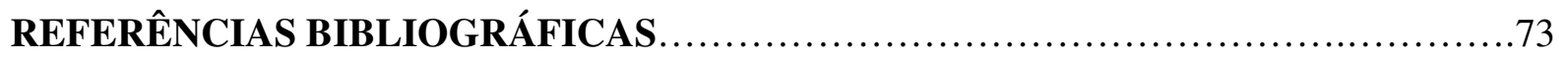

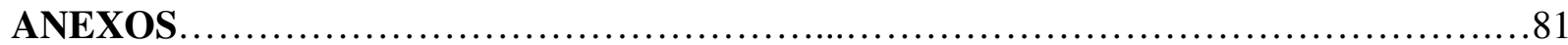

ANEXO A - The cross-talk between Thyroid Hormone and the Renin Angiotensin System

ANEXO B - Angiotensin type 1 receptor mediates Thyroid Hormone-induced cardiomyocyte hypertrophy through the Akt/GSK-3 $\beta /$ mTOR signaling pathway 


\section{INTRODUÇÃO}

\subsection{Hipertrofia Cardíaca}

Durante o desenvolvimento embrionário, bem como na vida pós-natal, as células cardíacas são continuamente expostas a diversos sinais aos quais elas respondem através da modulação de diversas vias de sinalização intracelular, que, geralmente, acabam por culminar com a alteração da expressão gênica (WEBER e BRILLA, 1991). Entre as células cardíacas que formam o tecido cardíaco propriamente dito temos os cardiomiócitos, os quais, embora correspondam a apenas cerca de 1/3 do número total de células cardíacas, ocupam, graças a seu volume, cerca de $75 \%$ do espaço estrutural do coração (LIJNEN e PETROV, 1999). Estas são células totalmente diferenciadas, perdendo a capacidade de proliferar rapidamente após o nascimento. Quando o coração é submetido a diversos estímulos, por exemplo, a uma situação de sobrecarga de pressão e/ou volume, os cardiomiócitos aumentam sua área como um mecanismo adaptativo, compensatório, denominado hipertrofia. Com a continuidade da imposição do estímulo, este mecanismo pode vir a tornar-se "descompensado", resultando em um processo de insuficiência cardíaca (LORELL e CARABELLO, 2000). Hoje, o desenvolvimento da hipertrofia cardíaca tem sido considerado um processo extremamente complexo, o qual pode ser mediado por fatores mecânicos, neuronais e hormonais (CHIEN et al., 1991; SADOSHIMA e IZUMO, 1997). Neste sentido, diversos agentes como, por exemplo, agonistas $\alpha$ e $\beta$ adrenérgicos (LONG et al., 1991), endotelina-1 (RUBANYI e POLOKOFF, 1994), Angiotensina II (Ang II) (SADOSHIMA e IZUMO, 1993) e hormônios tiroideanos (HT) (DENG et al., 2000) correspondem a estímulos diretamente implicados no desenvolvimento da hipertrofia cardíaca.

Em nível celular, a hipertrofia é caracterizada por um aumento do volume celular do cardiomiócito, o qual é acompanhado por aumento da síntese protéica total, aumento da transcrição de genes de resposta primária e pela re-expressão de genes expressos durante o período fetal, como a $\alpha$-actina esquelética e o fator natriurético atrial (ANF) (SADOSHIMA e IZUMO, 1997; AKAZAWA e KOMURO, 2003), os quais têm sido amplamente utilizados como marcadores de hipertrofia cardíaca (SCHAUB et al., 1997). Atualmente sabe-se que os eventos moleculares que sinalizam a hipertrofia são compostos por inúmeras vias de sinalização intracelular paralelas, as quais podem convergir, e acabar por sinalizar uma resposta comum. 
Neste sentido, várias proteínas quinases têm sido apresentadas como efetores envolvidos na ativação de receptores que traduzem sinais deflagrados, por exemplo, pela Ang II (MOLKENTIN, 2004; ZHANG e BROWN, 2004; DORN e FORCE, 2005). Mais recentemente, diversos estudos experimentais relataram que a inibição do crescimento hipertrófico normalmente resulta em uma melhora da disfunção do ventrículo esquerdo (YUSUF et al., 2000; FREY et al., 2004). Desta forma, a elucidação da contribuição dos diversos mecanismos envolvidos na modulação do trofismo cardíaco é fundamental para a melhor compreensão do processo hipertrófico como um todo, possibilitando, dessa forma, o desenvolvimento de estratégias terapêuticas mais eficazes.

\subsection{Sistema Renina Angiotensina}

Como citado anteriormente, um importante sistema hormonal relacionado à homeostase do tecido cardíaco é o Sistema Renina Angiotensina (SRA). Por quase um século o SRA foi classificado como um sistema endócrino, cujo hormônio efetor, a Ang II, era o principal responsável pelos efeitos fisiológicos. No entanto, hoje se sabe que esse sistema é muito mais amplo do que o inicialmente suposto, com a ação de inúmeras outras enzimas, que resultam na formação de peptídeos biologicamente ativos, os quais ao interagirem com receptores específicos acabam auxiliando na regulação deste sistema como um todo (SANTOS et al., 2008). Neste sentido, os mecanismos que controlam a formação, a degradação ou a ação da Ang II em um determinado tecido são fundamentais na determinação dos efeitos fisiológicos ou patológicos deste peptídeo no organismo (Figura 1). 


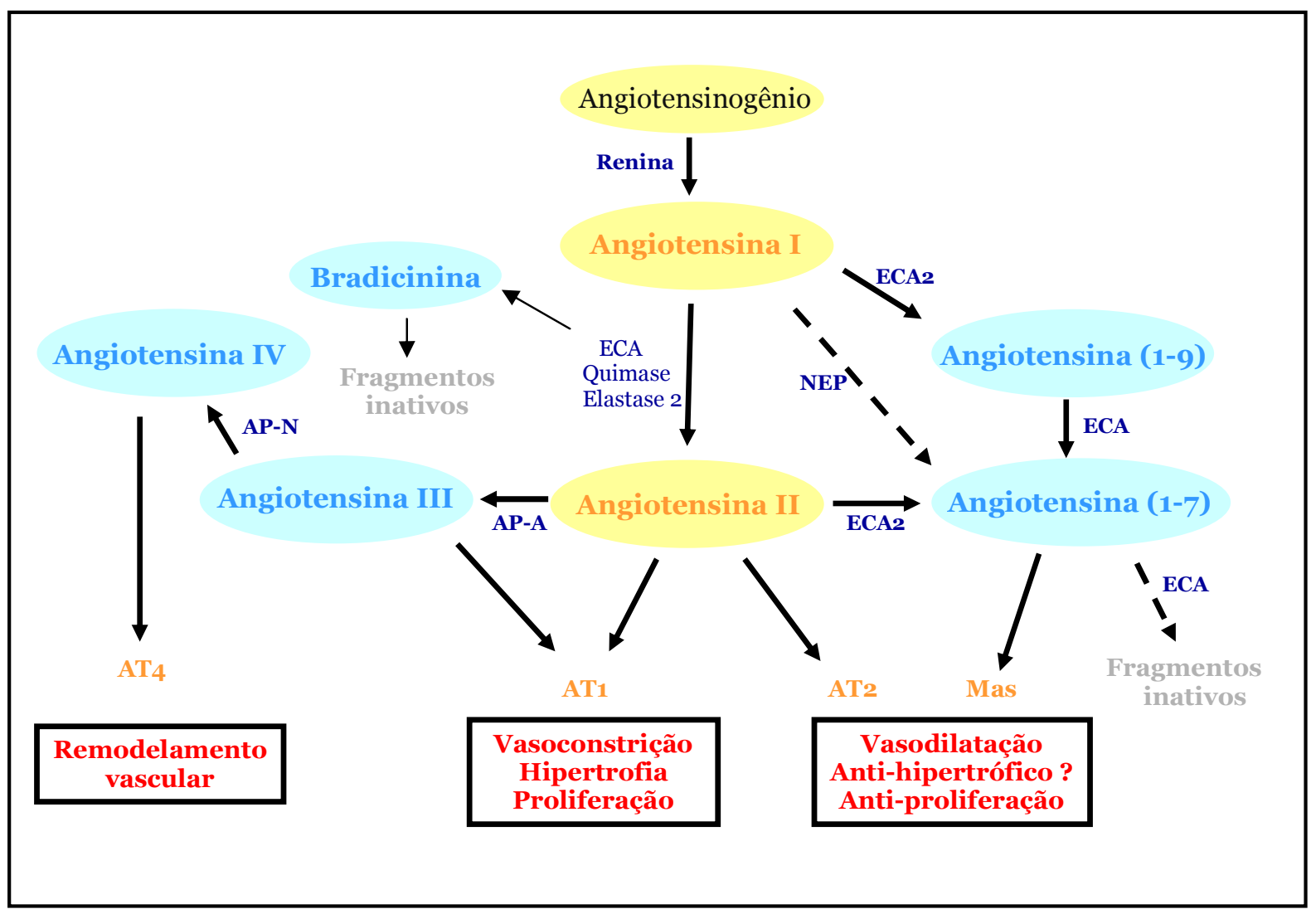

Figura 1- Esquema representativo dos principais componentes do SRA (Adaptado de WARNER et al., 2004).

A visão clássica deste sistema hormonal tem como primeiro componente a renina, uma enzima proteolítica sintetizada e estocada nas células justaglomerulares, a qual é secretada em situações de hipotensão e hipovolemia. A renina cliva seu substrato, o angiotensinogênio, o qual é sintetizado e secretado principalmente pelo fígado, gerando o decapeptídeo Angiotensina I (Ang I). Este decapeptídeo é posteriormente convertido em um octapeptídeo, a Ang II, ao ser clivado pela Enzima Conversora de Angiotensina (ECA), presente principalmente nas células endoteliais da circulação pulmonar. As ações clássicas da Ang II atuam no sentido de inverter a hipovolemia e a hipotensão, que são os principais responsáveis pela ativação desta cascata de eventos, a qual excerce seus efeitos através de dois receptores distintos, o receptor de Ang II do tipo 1 (AT1) e do tipo 2 (AT2). 
No final da década de 80, a existência de SRA locais, ou teciduais, foi descrita pela primeira vez. Com o desenvolvimento de técnicas mais sofisticadas de biologia molecular tornouse então possível comprovar a existência do RNA mensageiro (RNAm) e da proteína dos diversos componentes do SRA em vários tecidos. Baseado nessas evidências Dzau (DZAU, 1986) propôs o conceito de SRA local ou tecidual, o qual é capaz de gerar Ang II independente do SRA clássico, e encontra-se presente no coração e em células cardíacas isoladas (RE, 2004). Desta forma, a geração de Ang II que ocorre na circulação é complementada pelos SRA locais, os quais têm importantes funções homeostáticas e, por vezes, implicações patológicas. Neste sentido, é importante ressaltar que os peptídeos de angiotensina encontrados no tecido cardíaco apresentam-se em concentrações superiores às encontradas no plasma (LINDPAINTNER et al., 1988). Aproximadamente $90 \%$ de Ang I e $75 \%$ de Ang II presentes no coração são provenientes de síntese local (VAN KATS et al., 1998), demonstrando, portanto, a importância do SRA local para a manutenção dos níveis desses peptídeos no tecido cardíaco.

Paralelamente às propriedades endócrinas da Ang II, diversos estudos evidenciaram importantes efeitos autócrinos e parácrinos deste peptídeo no coração (DZAU, 1988; DANSER, 1996; BAKER et al., 2004). Mais recentemente, demonstrou-se também a existência de um SRA intracelular, ou intrácrino, capaz de gerar Ang II no interior da célula, o qual também está presente nos cardiomiócitos (KUMAR e BOIM, 2009).

Até o presente momento, dois receptores acoplados à proteína $\mathrm{G}$ são descritos como mediadores das ações exercidas pela Ang II, o AT1 e o AT2. O receptor AT1 é uma proteína integral de membrana, responsável por mediar a maioria dos efeitos fisiológicos e hipertróficos induzidos pela Ang II, sendo considerado por muitos pesquisadores como um ponto-chave de controle dos efeitos locais exercidos por esse peptídeo (MEHTA e GRIENDLING, 2007). Este é responsável por induzir respostas inflamatórias envolvidas com estresse oxidativo, promover efeitos cronotrópicos e inotrópicos positivos no coração, induzir apoptose, além de ativar vias relacionadas ao crescimento e proliferação celular, que acabam por culminar com a hipertrofia cardíaca (DORN, 2009). Em ratos, o receptor AT1 apresenta dois subtipos, o AT1a, localizado no cromossomo 17, e o AT1b, localizado no cromossomo 2 (GRIENDLING et al., 1996; HUNYADY e CATT, 2006). Devido à alta similaridade entre estes dois subtipos de receptores, cerca de $95 \%$, tem sido difícil o desenvolvimento de antagonistas específicos que possibilitem distinguir o papel exato de cada um destes subtipos de receptor (DE GASPARO et al., 2000). 
O receptor AT2, por sua vez, apresenta pequena homologia em relação ao receptor AT1 quanto à sequência de aminoácidos (VOLPE et al., 2003). Estes receptores são altamente expressos durante o período fetal, e logo após o nascimento têm a sua expressão drasticamente reduzida, ficando restrita a poucos órgãos, incluindo os do sistema cardiovascular (HUANG et al., 1996; BEDECS et al., 1997). Ao contrário do receptor AT1, o papel fisiológico do receptor AT2 ainda é muito controverso. Apesar da visão clássica do receptor AT2 ser atribuída à inibição do crescimento (HORIUCHI et al., 1999), recentemente, alguns estudos demonstram que este receptor também exerce efeitos hipertróficos. Nesse sentido, o receptor AT2 mostrou ser essencial para o desenvolvimento da hipertrofia cardíaca induzida por sobrecarga de pressão (SENBONMATSU et al., 2000). Além disso, a ativação do receptor AT2 parece ser capaz de promover diretamente a hipertrofia dos cardiomiócitos, independentemente da ligação da Ang II (D'AMORE et al., 2005).

O papel fundamental que o SRA exerce sobre a função cardiovascular tem sido demonstrado ao longo das últimas décadas, uma vez que o bloqueio do SRA, através da utilização de inibidores específicos para ECA ou antagonistas do receptor AT1, é capaz de atenuar a hipertensão arterial, diabetes, falência cardíaca, aterosclerose e remodelamento ventricular (ORO et al., 2007). Mais recentemente, a contribuição fisiológica predominante do SRA cardíaco foi vinculada ao equilíbrio do crescimento e proliferação celular, bem como ao importante papel mediador de respostas adaptativas do tecido cardíaco em situações de estiramento (PAUL et al., 2006). Dessa forma, a Ang II no tecido cardíaco, através do receptor AT1, age como um potente fator trófico, promovendo a hipertrofia dos cardiomiócitos. Esse efeito hipertrófico da Ang II envolve a ativação paralela e sequencial de diversas proteínas quinases associadas a diversas vias de sinalização, dentre as quais se destaca a ativação da via $\mathrm{PI} 3 \mathrm{~K} / \mathrm{Akt} / \mathrm{mTOR}$, a qual será detalhadamente discutida a seguir. Como citado anteriormente, embora a hipertrofia dos cardiomiócitos seja inicialmente um mecanismo compensatório para preservar a função cardíaca, este processo pode se tornar com o tempo um enorme fator de risco para o desenvolvimento da insuficiência cardíaca e consequente mortalidade (DZAU et al., 2001; PAUL et al., 2006). Nesse sentido, já foi demonstrado que a ação de inibidores do SRA, além de exercerem seus efeitos sistêmicos, exercem também efeitos celulares, influenciando diretamente o processo de remodelamento cardíaco (PAUL et al., 2006), ressaltando mais uma vez o envolvimento do SRA local para o controle do processo de hipertrofia cardíaca. 


\subsection{Sinalização intracelular deflagrada pela ativação do Receptor AT1}

O receptor AT1 influencia diversos processos fisiológicos e patológicos que acometem o sistema cardiovascular. Por esse motivo, o receptor AT1 é um dos principais alvos terapêuticos no tratamento de várias doenças cardíacas e vasculares (APLIN et al., 2008).

A Ang II, ao se ligar ao receptor AT1, promove a sua ativação através de uma mudança conformacional, o que deflagra a ativação de diversas cascatas de sinalização intracelular, como cálcio, fosfolipase $\mathrm{C}$, proteína quinase $\mathrm{C}$, proteína quinase $\mathrm{A}$, hidrólise de trifosfato de inositol, hidrólise de fosfolípides de membrana, liberação de diacilglicerol, família das MAPKs, adenilato ciclase, via JAK/STAT, 90-KD S6 quinase, 70-kD S6 quinase, c-Jun NH2-terminal quinase e $\mathrm{PI} 3 \mathrm{~K} / \mathrm{Akt} / \mathrm{mTOR}$. O receptor AT1 ativado é então fosforilado, o que promove o recrutamento da $\beta$-arrestina. A ligação da $\beta$-arrestina ao receptor bloqueia a sua interação com proteínas $\mathrm{G}$ e, consequentemente, finaliza a primeira etapa da sinalização. Além disso, a $\beta$-arrestina também auxilia a internalização do receptor e inicia uma segunda etapa de ativação, a qual envolve a ativação de diversas proteínas quinases (APLIN et al., 2008). As vias de sinalização intracelular deflagradas pela ativação do receptor AT1 ativam diversos fatores de transcrição (ROCIC et al., 2001; BADER, 2002; THOMAS et al., 2002; APLIN et al., 2008), além de promoverem também a re-expressão de genes fetais, como a $\alpha$-actina esquelética e ANF em cardiomiócitos (SADOSHIMA e IZUMO, 1993; TAKANO et al., 1996; KUDOH et al., 1997; SCHAUB et al., 1997) e ainda estimularem a síntese de proteínas, resultando, por fim, no desenvolvimento da hipertrofia cardíaca.

Além do SRA, outros importantes hormônios relacionados à homeostase do sistema cardiovascular são os hormônios tiroideanos $\left(\mathrm{T}_{3}\right.$ e $\left.\mathrm{T}_{4}\right)$, os quais são descritos a seguir.

\subsection{Hormônios Tiroideanos e o Coração}

Atualmente, estima-se que as doenças que afetam a glândula tiróide atinjam mais de $10 \%$ da população. Paralelamente, diversos estudos evidenciaram uma estreita relação entre os níveis de hormônios tiroideanos (HT) e a função cardíaca (CANARIS et al., 2000), sendo que 
alterações dos níveis desses hormônios são capazes de aumentar o fator de risco para o desenvolvimento e a progressão das doenças cardiovasculares (SCHMIDT-OTT e ASCHEIM, 2006; PANTOS et al., 2007). Os HT promovem hipertrofia cardíaca agindo diretamente sobre o tecido cardíaco, alterando quantitativa e qualitativamente a sua síntese protéica (KLEIN e LEVEY, 1984) e, indiretamente, através de ações hemodinâmicas, por meio das quais alteram a função e a estrutura do coração. Os efeitos exercidos pelos HT nos cardiomiócitos estão intimamente associados à função cardíaca, através da regulação da expressão de genes estruturais e genes regulatórios (DAVIS et al., 2008).

A visão clássica dos efeitos dos HT foi, por muito tempo, caracterizada como resultante de ações exclusivamente genômicas. Desta forma, após acesso do HT ao interior da célula, ocorreria a translocação de HT para o núcleo, o qual induziria à alteração da razão de transcrição gênica, tradução, mudanças no conteúdo celular ou secreção de proteínas específicas. Para que essas ações genômicas ocorram são necessárias algumas horas (DAVIS et al., 2007). No entanto, recentemente, uma nova visão no que diz respeito à ação dos HT foi proposta, denominada de ação não genômica. Neste sentido, diversos estudos demonstraram que o $T_{3}$ exerce alguns efeitos rapidamente, que ocorrem em questão de segundos ou minutos, os quais não são alterados por inibidores de transcrição ou de síntese protéica (DAVIS et al., 2000; WRUTNIAK-CABELLO et al., 2001; DAVIS e DAVIS, 2002) e independem inicialmente da formação do complexo intranuclear entre HT e receptor de hormônio tiroideano (RHT) (DAVIS e DAVIS, 2002; DAVIS et al., 2007). Os efeitos não genômicos dos HT podem ocorrer em decorrência da sua ligação a proteinas presentes na membrana plasmática ou a receptores localizados no citoplasma, os quais, por sua vez, são capazes de ativar diversas vias de sinalização intracelular (BERGH et al., 2005; DAVIS et al., 2008). Através destas, o HT atua em várias cascatas de sinalização, como ocorre com a via de sinalização das MAPKs (LIN et al., 1999; DAVIS et al., 2000; KOZAWA et al., 2001; SHIH et al., 2001) e vias deflagradas por ativação da PKC (ALISI et al., 2004). Além disso, recentemente foi identificado um sítio de ligação para HT na integrina $\alpha \mathrm{V} \beta 3$, o que promove a ativação de ERK1/2 (DAVIS et al., 2005), resultando em angiogênese (BERGH et $a l .$, 2005) e proliferação celular (DAVIS et al., 2006). 


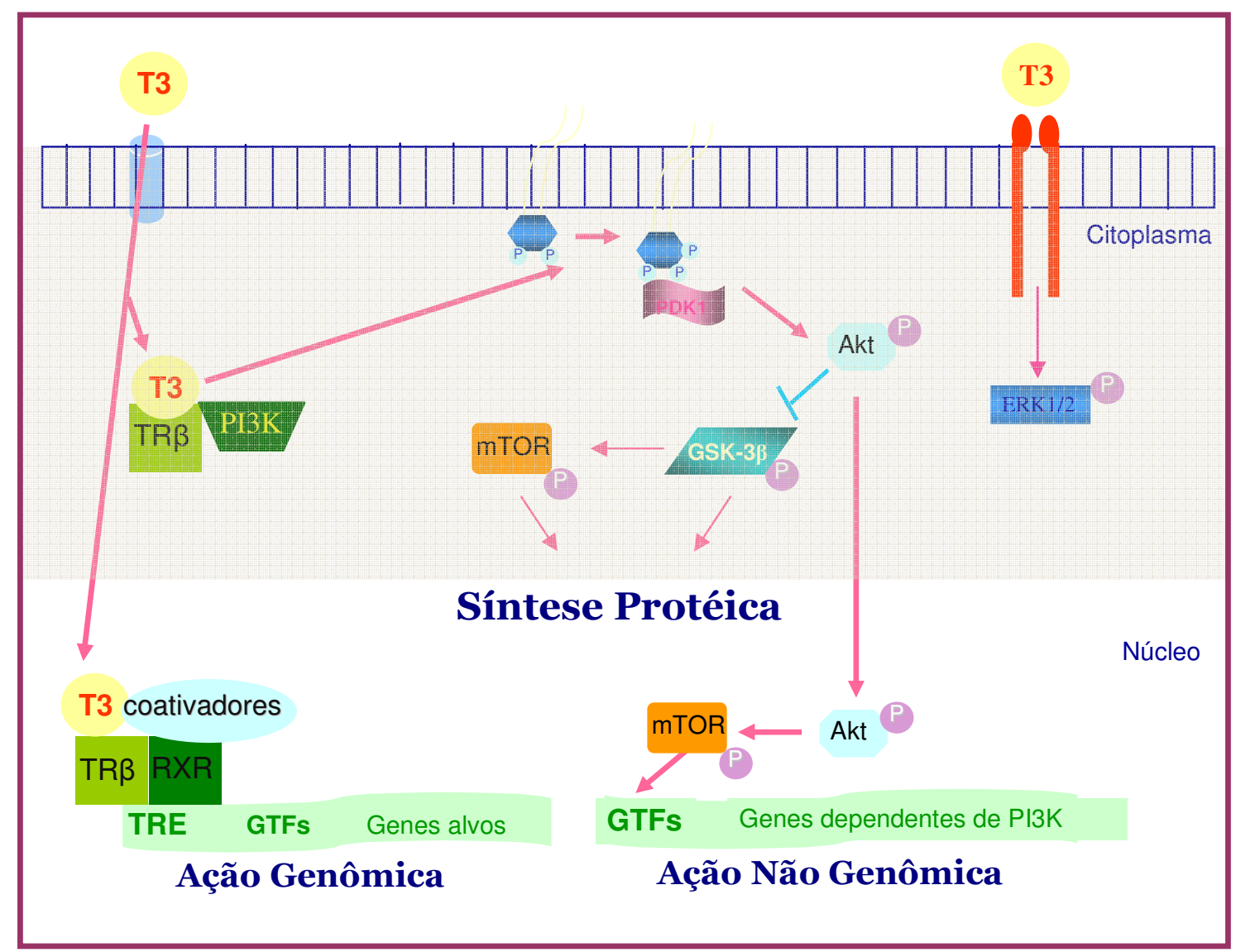

Figura 2- Esquema representativo de algumas das ações genômicas e não genômicas exercidas pelo $\mathrm{T}_{3} \mathrm{em}$ cardiomiócitos (adaptado de MOELLER et al., 2006).

Nos últimos anos, a ativação da via PI3K/Akt/mTOR foi descrita como uma importante mediadora do processo de hipertrofia cardíaca induzida pelo HT. O primeiro estudo nesse sentido demonstrou que ratos induzidos ao hipertiroidismo apresentam um aumento dos níveis de Akt, mTOR, GSK-3 $\beta$ e S6-quinase fosforiladas no coração, os quais podem contribuir para os efeitos hipertróficos exercidos pelo HT no tecido cardíaco (KUZMAN et al., 2005). Estudos in vitro também demonstraram o efeito do HT na ativação da via da Akt. Neste sentido, culturas de cardiomiócitos submetidas ao tratamento com $\mathrm{T}_{3}$ apresentam ativação da via Akt/GSK$3 \beta /$ mTOR, a qual preveniu a apoptose induzida pela retirada de soro destas células (KUZMAN et al., 2005). Outro recente trabalho demonstrou ainda que culturas de cardiomiócitos tratadas com $\mathrm{T}_{3}$ apresentam um rápido aumento dos níveis de Akt fosforilada, o qual é mediado pela interação entre PI3K e TR $\alpha 1$ (KENESSEY e OJAMAA, 2006). Ainda, a utilização de inibidores de PI3K (KENESSEY e OJAMAA, 2006) e mTOR (KUZMAN et al., 2007) são capazes de 
prevenir o desenvolvimento da hipertrofia dos cardiomiócitos promovida pelo HT in vitro, implicando a participação dessa via no efeito hipertrófico exercido pelo HT nessas células.

Dessa forma, os trabalhos recentemente descritos na literatura demonstram claramente que o desenvolvimento da hipertrofia cardíaca promovido pelos HT é um processo bastante complexo, o qual envolve não somente a alteração da transcrição de inúmeros genes, como também a rápida modulação do estado de fosforilação de algumas proteínas quinases, bem como a participação destas no controle do trofismo cardíaco.

\subsection{Via de sinalização PI3K/Akt/GSK3-ß/mTOR e Hipertrofia Cardíaca}

Uma das vias envolvidas diretamente no processo de hipertrofia cardíaca induzido tanto pela Ang II, como também por elevados níveis de HT, é a via PI3K/Akt/GSK3- $\beta / m T O R$. Embora a Akt tenha efeitos benéficos, relacionados à indução do crescimento e efeitos anti-apoptóticos, a ativação desta via de sinalização encontra-se frequentemente associada a diversas doenças cardiovasculares, como hipertensão, hipertrofia e falência cardíaca (OUDIT et al., 2004; BENKIRANE et al., 2006). No coração e em cardiomiócitos isolados a PI3K, a qual se encontra ligada a receptores acoplados à proteina $\mathrm{G}$, através da ativação da Akt e suas proteínas alvos, tem sido implicada em diversos modelos de hipertrofia cardíaca (NAGA PRASAD et al., 2000; MATSUI et al., 2003; OUDIT et al., 2004). Esse processo inicia-se após a ligação da Ang II ao receptor AT1, o que resulta na ativação da subunidade $\beta \gamma$ da proteína $\mathrm{Gq}$, a qual então induz à ativação da PI3K. Esta, por sua vez, fosforila fosfatidil-inositóis de membrana, culminando com a formação de fosfatidil-inositol trifosfato (PiP3) (DORN e FORCE, 2005), os quais irão regular a ativação de outras proteínas quinases. Em seguida, PiP3 liga-se à Akt, o que resulta em sua translocação para a membrana plasmática. Posteriormente, a quinase 1 dependente de fosfoinositol (PDK1), juntamente com outras quinases dependentes de PI3K, fosforilam e ativam várias proteínas, dentre as quais se destaca a fosforilação da Akt (TOKER e NEWTON, 2000; VANHAESEBROECK e ALESSI, 2000), a qual é responsável por mediar a fosforilação de outras proteínas, como a GSK3- $\beta$ e a mTOR (Figura 3 ). 


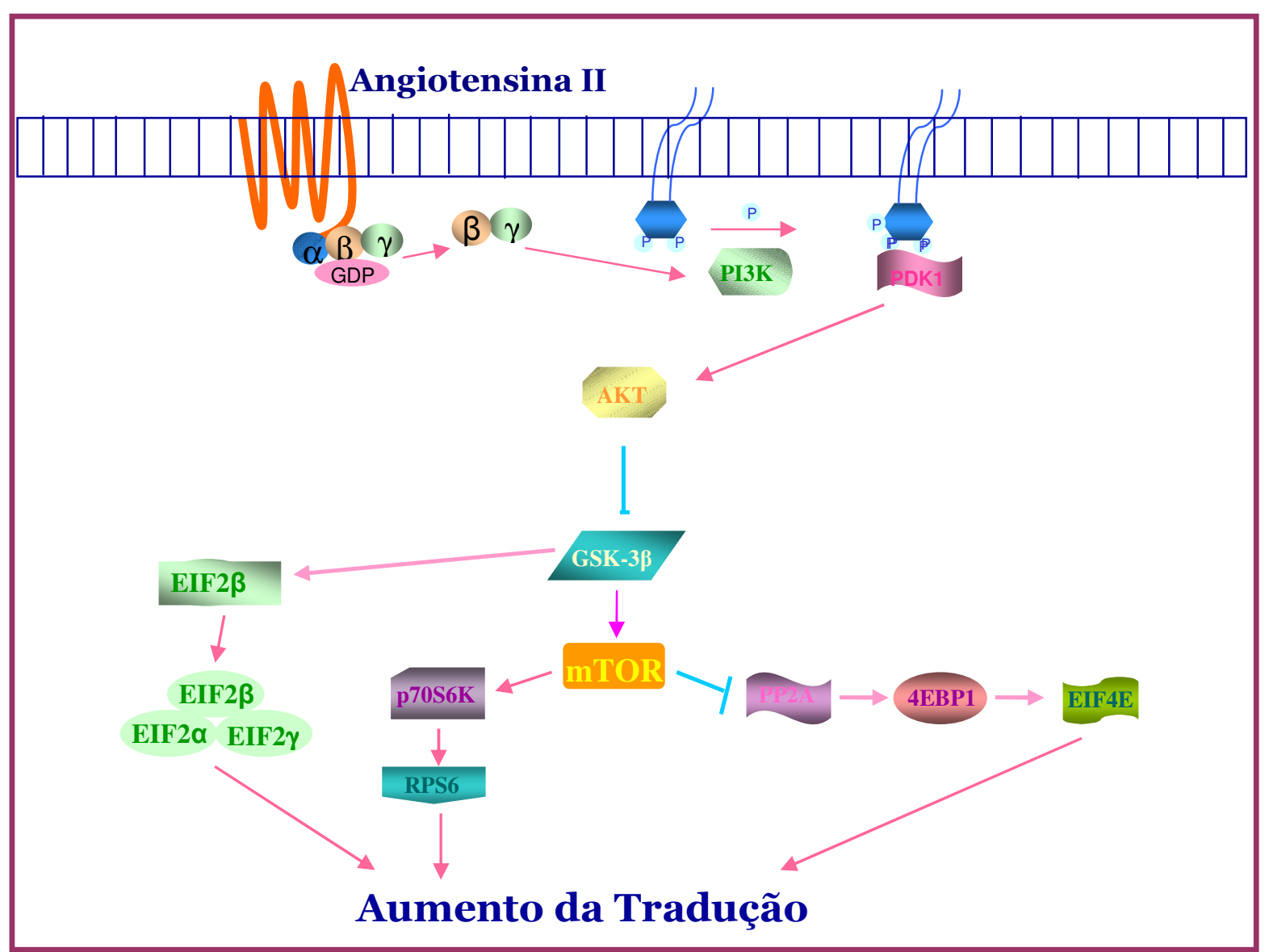

Figura 3- Esquema representativo de algumas das proteínas da via PI3K/Akt/GSK3- $\beta /$ mTOR ativadas pela Ang II através do receptor AT1.

A Akt é uma proteína serina/treonina quinase envolvida na regulação de diversas funções celulares do tecido cardíaco, como crescimento dos cardiomiócitos, sobrevivência, função contrátil e angiogênese coronariana (SHIOJIMA e WALSH, 2006). Esta é ativada por fosforilação no resíduo treonina 308 pela PDK1 (ALESSI et al., 1997) e no resíduo serina 473 na porção carboxi-terminal pela PDK2 (GUERTIN et al., 2006). Uma vez ativada, a Akt pode fosforilar e inibir a serina/treonina quinase GSK-3ß, a qual é uma proteína que inibe componentes da maquinaria de tradução e vários fatores de transcrição relacionados à indução do programa de expressão gênica relacionado à hipertrofia. Além disso, a Akt ativada irá promover também a fosforilação e ativação da mTOR, outra importante proteína reguladora da síntese protéica, através de suas ações tanto na biogênese dos ribossomos, como também na maquinaria de tradução protéica. Dessa forma, a fosforilação de GSK3- $\beta$ e da mTOR, por ativação da Akt, 
irá contribuir diretamente para o processo de hipertrofia cardíaca (HARDT e SADOSHIMA, 2002; OUDIT et al., 2004).

\subsection{Sistema Renina Angiotensina e Hormônios Tiroideanos}

Além dos efeitos diretos promovidos pelos HT no coração e no sistema vascular, nas últimas três décadas vários estudos evidenciaram que o SRA está envolvido em alguns efeitos dos HT no sistema cardiovascular, como recentemente apontado em nossa revisão (BARRETOCHAVES et al., 2009, ANEXO A), sugerindo que o SRA pode ser um importante mediador das ações dos HT. Nesse contexto, alguns trabalhos evidenciaram a participação do SRA também no desenvolvimento da hipertrofia cardíaca promovida por elevados níveis de HT. O grupo do Kobori foi um dos primeiros a sugerir a contribuição do SRA local neste modelo de hipertrofia (KOBORI et al., 1999) e a demonstrar um aumento da expressão de renina in vivo (KOBORI et al., 1997) e in vitro (ICHIHARA et al., 1998). Mais recentemente, nosso laboratório mostrou que a utilização de inibidores específicos de componentes do SRA, como antagonista do receptor AT1, inibidor da ECA (HU et al., 2003) ou antagonista do receptor AT2 (CARNEIRO-RAMOS et al., 2009), foi capaz de atenuar o desenvolvimento da hipertrofia cardíaca induzida pelo HT in vivo. Este modelo de hipertrofia é ainda caracterizado por aumento da expressão de TGF- $\beta 1$ no coração, outro importante fator trófico, o qual também é mediado pelos receptores de Ang II, como demonstramos recentemente (DINIZ et al., 2007).

Considerando que os HT modulam uma série de parâmetros hemodinâmicos, os quais poderiam influenciar os resultados relacionados à modulação do SRA, estudos utilizando culturas de células vêm sendo amplamente empregados por diversos autores e também pelo nosso grupo. 


\section{JUSTIFICATIVA}

As doenças do sistema cardiovascular representam a primeira causa de morbidade e mortalidade em humanos, promovendo mais de 16 milhões de mortes por ano (the World Health Organization), ressaltando a necessidade da compreensão dos mecanismos implicados nesses processos. Grande parte das doenças cardiovasculares que atingem pricipalmente o idoso é decorrente de alterações nos níveis séricos de HT, sendo que estes, quando elevados, resultam na instalação de um processo de hipertrofia cardíaca, a qual pode levar à diminuição da função ventricular esquerda e, portanto, à insuficiência cardíaca (BARRY et al., 2008). Diversos fatores são capazes de induzir a hipertrofia do coração, a qual pode acabar culminando em falência cardíaca, e até mesmo em morte súbita (VAN ROOIJ et al., 2007), dentre os quais se destacam a Ang II e o HT. Nesse contexto, é importante destacar que a prevalência de disfunção tireoidiana está aumentando constantemente nos países ocidentais, o que tem sido atribuído em grande parte ao envelhecimento da população (WEISSEL, 2006). Ainda, nas últimas duas décadas, diversos estudos evidenciaram uma estreita relação entre os níveis de HT e a função cardíaca, os quais demonstraram que alterações dos níveis desses hormônios são capazes de aumentar o fator de risco para o desenvolvimento e a progressão das doenças cardiovasculares (SCHMIDT-OTT e ASCHEIM, 2006; PANTOS et al., 2007).

Considerando que a existência de uma estreita relação entre SRA e os HT vem sendo cada vez mais bem caracterizada, e ainda o fato de que tanto a Ang II como os HT são capazes de promover hipertrofia cardíaca, bem como modular a via de sinalização da PI3K/Akt/GSK3$\beta /$ mTOR, torna-se necessário avaliar se o receptor AT1, presente nos cardiomiócitos, está envolvido no processo de hipertrofia induzido pelo HT, ou ainda pode atuar como um mediador da ativação dessa via de sinalização promovida pelo HT. Nesse sentido, a elucidação da possível contribuição do receptor AT1 para o efeito hipertrófico do HT poderá desvendar a existência de um novo mecanismo pelo qual o HT exerce efeitos hipertróficos sobre os cardiomiócitos. 


\section{OBJETIVO GERAL}

Avaliar a participação do receptor AT1 para o desenvolvimento da hipertrofia de cardiomiócitos induzido pelo $\mathrm{T}_{3}$.

\subsection{OBJETIVOS ESPECÍFICOS}

1- Avaliar a contribuição do receptor AT1 para a ativação da via Akt/GSK3- $\beta / m T O R$ promovida pelo $\mathrm{T}_{3}$ em culturas de cardiomiócitos.

2- Analisar a participação da PI3K para a ativação da via Akt/GSK3- $\beta / m$ TOR induzida pelo $\mathrm{T}_{3}$ em culturas de cardiomiócitos.

3- Avaliar o efeito do $T_{3}$ nos níveis de Ang I/II e na expressão gênica e protéica do receptor AT1 em culturas de cardiomiócitos. 


\section{MATERIAIS E MÉTODOS}

\subsection{Culturas primárias de cardiomiócitos}

Para a obtenção das culturas primárias de cardiomiócitos foram utilizados ratos neonatos Wistar de 1 a 3 dias, de acordo com o protocolo descrito previamente (BARRETO-CHAVES et al., 2000). Para cada experimento (n) foram utilizados 10 neonatos, obtendo aproximadamente 8 placas de cultura de 6 poços em cada experimento, com uma densidade de 200x $10^{4}$ células/placa. Após exposição do coração, os ventrículos foram separados dos átrios, e então submetidos a um processo de digestão enzimática em tampão à base de colagenase (Worthington, Lakewood, New Jersey, USA) e pancreatina (GIBCO, Grand Island, New York, USA). Após sucessivas digestões enzimáticas, os homogenatos celulares foram submetidos à centrifugação em um gradiente descontínuo de Percoll ${ }^{\mathrm{TM}}$ (Amersham Biosciences, Sweden), permitindo então a separação dos cardiomiócitos dos demais tipos celulares presentes no coração. A viabilidade celular foi estimada pelo uso de um corante (Trypan Blue Stain $0.4 \%$, GIBCO). Em seguida os cardiomiócitos foram contados em hemocitômetro e plaqueados em meio DMEM (Dulbecco's modified Eagle's medium, Invitrogen, Carlsbad, California, USA) suplementado com $5 \%$ de soro de bezerro neonato (NCS, Invitrogen) e $10 \%$ de soro de cavalo (HS, Invitrogen). As placas foram mantidas em estufa de $\mathrm{CO}_{2}$ a $37{ }^{\circ} \mathrm{C}$, sob condições estéreis, até a realização dos experimentos.

\subsection{Caracterização das culturas primárias de cardiomiócitos}

Inicialmente, as culturas primárias de cardiomiócitos foram caracterizadas através da morfologia típica das células in vitro, associada à observação da capacidade contrátil que apresentam em cultura. Posteriormente, as células foram fenotipicamente caracterizadas por imunocitoquímica, através da utilização do anticorpo Anti-Tropomiosina Sarcomérica (Sigma Immunochemicals, St. Louis MO, USA). A marcação com anticorpo específico para fibroblastos (Anti-Vimentina, Sigma Immunochemicals), os quais poderiam, eventualmente, contaminar as culturas de cardiomiócitos, também foi utilizada como controle negativo. Utilizou-se um anticorpo secundário ligado à fluorescência $\left(\mathrm{Cy}^{\mathrm{TM}}-3\right.$, Jackson Immuno Research) para evidenciar 
a marcação. As lâminas foram coradas com DAPI (Sigma Chemicals), permitindo a visualização dos núcleos em azul, e em seguida foram analisadas em microscópio de fluorescência (LEICA DMR, Germany).

\subsection{Transfecção das células com RNAi}

Para avaliar a participação do receptor AT1 na hipertrofia dos cardiomiócitos induzida pelo $T_{3}$, bem como para a ativação da via de sinalização da Akt, utilizamos a técnica de RNAi para silenciar este receptor.

Inicialmente foi utilizado um RNA dupla-fita controle positivo ligado a fluoresceína (BLOCK-iT ${ }^{\mathrm{TM}}$ Fluorescent Oligo, Invitrogen), o qual possui as mesmas características que a molécula de RNAi, no entanto, incapaz de reconhecer e silenciar transcritos produzidos pelas células. Paralelamente, foi utilizado também um controle negativo (Stealth ${ }^{\mathrm{TM}}$ RNAi Negative Control High GC Duplexes, Invitrogen) para cada experimento com RNAi, o qual corresponde a uma sequência de oligonucleotídeos que não reconhece nenhum transcrito produzido pela célula. O uso do controle negativo é indispensável para avaliar possíveis efeitos não específicos na expressão gênica, causados pela introdução do RNAi nas culturas de células. Utilizamos o reagente Lipofectamine ${ }^{\mathrm{TM}} 2000$ (Invitrogen) para a transfecção das células. Algumas condições são determinantes e fundamentais para uma boa eficiência de transfecção: a densidade de células (1), volume de lipofectamina ideal para introduzir o RNAi (2), a concentração de RNAi (3), a presença de soro no meio de transfecção (4), tempo necessário para que ocorra a transfecção (5) e a meia-vida da proteína (6). Assim, para a padronização do protocolo de transfecção, buscando a otimização e a maior eficiência do mesmo, foram realizadas as seguintes etapas, as quais não serão abordadas nesta tese:

1- Curva de plaqueamento com diferentes densidades celulares $\left(200 \times 10^{4}, 170 \times 10^{4}\right.$, $140 \times 10^{4}$ ou $100 \times 10^{4}$ células/placa).

2- Curva utilizando diferentes volumes de lipofectamina $(2.5,3$ ou $3.5 \mu 1$ de Lipofectamine $^{\mathrm{TM}} 2000 /$ well).

3- Curva utilizando diferentes concentrações de RNAi (10, 50, 100 ou 200ךM/well).

4- Análise da eficiência de transfecção na presença ou ausência de soro. 
Após o estabelecimento da melhor densidade de células $\left(200 \times 10^{4}\right.$ células/placa), do melhor volume de lipofectamina ( $3 \mu \mathrm{l} /$ well) e da melhor concentração de RNAi (50 $\eta \mathrm{M} / w e l l)$, utilizando para isso o RNAi controle positivo, é que iniciamos então os ensaios com RNAi para AT1. Ainda, a utilização de meio sem soro para os procedimentos de transfecção foi necessária para otimizar a eficiência de transfecção das células.

\subsubsection{Avaliação da eficiência de transfecção - Utilização de um RNAi controle positivo}

Para avaliar o número de células transfectadas com RNAi, estas foram submetidas às seguintes condições:

- Controle (células tratadas com DMEM)

- Controle positivo (células transfectadas com 50 ๆM de RNAi ligado a uma molécula fluorescente, BLOCK-iT ${ }^{\mathrm{TM}}$ Fluorescent Oligo).

Ao final de 24 horas após a transfecção, as células foram analisadas em microscópio confocal ou por citometria de fluxo.

\subsubsection{Avaliação do efeito da transfecção na expressão do receptor AT1 - Utilização de um RNAi controle negativo (Scramble RNAi)}

Para avaliar se a transfecção com RNAi controle negativo (sequência incapaz de reconhecer transcritos produzidos pelas células) poderia ser capaz de modular a expressão do receptor AT1, as células foram submetidas às seguintes condições:

- Controle (células tratadas com DMEM)

- Controle negativo (células transfectadas com 50 ๆM de RNAi controle negativo, Stealth ${ }^{\mathrm{TM}}$ RNAi Negative Control Duplexes, por 56, 72 ou 80 horas).

Após a transfecção das células, a proteína total foi extraída (após 56, 72 ou 80 horas) e utilizada para a avaliação da expressão protéica do receptor AT1, através da técnica de Western Blotting. 


\subsubsection{Avaliação da eficiência do silenciamento do receptor AT1 - Utilização de RNAi específico}

Inicialmente, foram utilizadas três sequências-alvo candidatas, distintas, obtidas da sequência completa de AT1 de Rattus rattus, espaçadas através do gene, com o intuito de avaliar qual delas proporcionava o maior grau de silenciamento do receptor AT1. As sequências selecionadas não são complementares a nenhuma outra sequência gênica, através de pesquisa no BLAST, confirmando, portanto, a especificidade dos RNAi ao receptor AT1 utilizados nestes experimentos. As sequências de RNAi (Stealth ${ }^{\mathrm{TM}} \mathrm{RNAi}$, Invitrogen) utilizadas apresentam alto (high), médio (medium) ou baixo (low) conteúdo de G/C:

\section{A) AT1 (5'-AUACGUUUCGGUAGAUGACGGCUGG-3')}

(5'-CCAGCCGUCAUCUACCGAAACGUAU-3').

B) AT1 (5'-AUAAGAGUAUAGCUGGUGAGAAUGA-3')

(5'-UCAUUCUCACCAGCUAUACUCUUAU-3').

C) AT1 (5'-UUAUAAGCCUUCUUUAGGGCUUUCC-3')

(5'-GGAAAGCCCUAAAGAAGGCUUAUAA-3').

As células foram submetidas às seguintes condições:

- Controle (células tratadas com DMEM)

- RNAi para AT1 (células transfectadas com $50 \eta \mathrm{M}$ de RNAi, Stealth ${ }^{\mathrm{TM}}$ RNAi, utilizando três sequências distintas de RNAi para AT1 por 24, 48, 56, 72 ou 80 horas).

Após a transfecção das células, o RNA total foi extraído (após 24, 48 ou 80 horas) e utilizado para os posteriores experimentos de RT-PCR em Tempo Real. Outros grupos de células foram ainda transfectados por 48, 56, 72 ou 80 horas para a avaliação da expressão protéica do receptor AT1, através da técnica de Western Blotting. A sequência de RNAi capaz de induzir o máximo silenciamento do receptor AT1 foi a que apresentava o maior conteúdo de GC (sequência A), a qual foi então utilizada para os demais experimentos, conforme descrito a seguir. 


\subsubsection{Avaliação da contribuição do receptor AT1 para a hipertrofia dos cardiomiócitos induzida pelo $\mathbf{T}_{3}$}

Para avaliar o possível papel do receptor AT1 para o desenvolvimento da hipertrofia dos cardiomiócitos promovida pelo $\mathrm{T}_{3}$, algumas células foram transfectadas com RNAi para AT1.

- Controle (células mantidas em DMEM)

- RNAi para AT1 (células transfectadas com 50 ๆM de RNAi para AT1 por 80 horas).

- RNAi para AT1 + $\mathrm{T}_{3}$ (células transfectadas com $50 \eta \mathrm{M}$ de RNAi para AT1 por 56 horas e posteriormente tratadas com $10 \eta \mathrm{M}$ de $\mathrm{T}_{3}$ por 24 horas).

- $\mathrm{T}_{3}$ (células tratadas com $10 \eta \mathrm{M}$ de $\mathrm{T}_{3}$ por 24 horas).

Ainda, para confirmar a possível participação do receptor AT1 neste modelo de hipertrofia, outros grupos de células foram pré-tratados por $30 \mathrm{~min}$ com um bloqueador farmacológico, o Losartan ( $1 \mu \mathrm{M}$, Sigma), e em seguida foram então submetidos ao tratamento combinado de bloqueador e $\mathrm{T}_{3}$.

- Controle (células mantidas em DMEM por 24 horas).

- Losartan (células tratadas com $1 \mu \mathrm{M}$ de Losartan por 24 horas).

- Losartan $+\mathrm{T}_{3}$ (células tratadas com $1 \mu \mathrm{M}$ de Losartan e $10 \eta \mathrm{M}$ de $\mathrm{T}_{3}$ por 24 horas).

A concentração de $T_{3}(10 \eta \mathrm{M})$ empregada neste estudo já foi utilizada em outros estudos do laboratório e é suficientemente capaz de induzir à hipertrofia dos cardiomiócitos, e por isso foi utilizada (WANG et al., 2006).

Ao final dos tratamentos, o RNA total foi extraído para a análise da expressão gênica de dois marcadores de hipertrofia cardíaca (ANF e $\alpha$-actina esquelética), através da técnica de RTPCR em Tempo Real. Outros grupos de células foram utilizados para a avaliação de síntese protéica, através do ensaio de incorporação de leucina triciada.

\subsubsection{Avaliação da contribuição do receptor AT1 para a ativação da via Akt/GSK3- $\beta / m$ TOR promovida pelo $T_{3}$}

Para avaliar a possível participação do receptor AT1 para a ativação da via da Akt promovida pelo $\mathrm{T}_{3}$, algumas células foram transfectadas com RNAi para AT1. 
- Controle (células mantidas em DMEM)

- $\mathrm{T}_{3}$ (células tratadas com $10 \eta \mathrm{M}$ de $\mathrm{T}_{3}$ por $5,10,15,30$ min e 24 horas).

- RNAi para AT1 (células transfectadas com 50 ๆM de RNAi para AT1 por 72 horas).

- RNAi para AT1 + $\mathrm{T}_{3}$ (células transfectadas com $50 \eta \mathrm{M}$ de RNAi para AT1 por $72 \mathrm{~h}$ e posteriormente tratadas com $10 \eta \mathrm{M}$ de $\mathrm{T}_{3}$ por $5,10,15$ e $30 \mathrm{~min}$ ).

Para confirmar a possível contribuição do receptor AT1 para a ativação da via da Akt promovida pelo $\mathrm{T}_{3}$, outros grupos de células também foram pré-tratados por $30 \mathrm{~min}$ com Losartan ( $1 \mu \mathrm{M}$, Sigma), e em seguida submetidos ao tratamento combinado de bloqueador e $\mathrm{T}_{3}$.

- Losartan (células tratadas com $1 \mu \mathrm{M}$ de Losartan).

- Losartan $+\mathrm{T}_{3}$ (células tratadas com $1 \mu \mathrm{M}$ de Losartan e $10 \eta \mathrm{M}$ de $\mathrm{T}_{3}$ por por 5, 10, 15 e $30 \mathrm{~min})$.

Após os tratamentos, a proteína total foi extraída e utilizada para a análise da expressão de Akt, GSK3- $\beta$ e mTOR através da técnica de Western Blotting.

\subsubsection{Análise da participação da PI3K para a ativação da via Akt/GSK3- $\beta$ /mTOR induzida pelo $\mathbf{T}_{3}$}

Para analisar a contribuição da PI3K para a ativação da via da Akt, as células foram prétratadas por 30 min com inibidores específicos da PI3K, LY294002 (10 $\mu \mathrm{M}$, Cell Signaling) ou Wortmannin (200 ๆM, Cell Signaling) e em seguida foram então submetidas ao tratamento combinado de inibidor da PI3K e $\mathrm{T}_{3}$.

- Controle (células tratadas com DMEM)

- LY294002 + $\mathrm{T}_{3}$ (células tratadas com $10 \mu \mathrm{M}$ de LY294002 e $10 \eta \mathrm{M}$ de $\mathrm{T}_{3}$ por 5, 10, 15 e $30 \mathrm{~min})$

- Wortmannin $+\mathrm{T}_{3}$ (células tratadas com $200 \eta \mathrm{M}$ de Wortmannin e $10 \eta \mathrm{M}$ de $\mathrm{T}_{3}$ por 5, $10,15$ e $30 \mathrm{~min})$

Ao final dos tratamentos, a proteína total foi extraída e utilizada para a análise da expressão de Akt, GSK3- $\beta$ e mTOR através da técnica de Western Blotting. 


\subsubsection{Avaliação do efeito do $T_{3}$ nos níveis de Ang $\mathrm{I} / \mathrm{II}$ e na expressão gênica e protéica do receptor AT1}

Para avaliar se o $\mathrm{T}_{3}$ seria capaz de modular os níveis de Ang I e Ang II no meio de cultura dos cardiomiócitos, realizou-se os seguintes tratamentos:

- Controle (células mantidas em DMEM)

- $\mathrm{T}_{3}$ (células tratadas com $10 \eta \mathrm{M}$ de $\mathrm{T}_{3}$ por 24 horas)

Após isso, o meio de cultura foi coletado e utilizado para as dosagens dos níveis de Ang I e Ang II por HPLC.

Para analisar o efeito do $\mathrm{T}_{3}$ na expressão de Ang I/II no lisado celular e na expressão do receptor AT1, as células receberam os seguintes tratamentos:

- Controle (células mantidas em DMEM)

- $\mathrm{T}_{3}$ (células tratadas com $10 \eta \mathrm{M}$ de $\mathrm{T}_{3}$ por 5, 10, 15, 30 min e 24 horas).

Após os tratamentos, a proteína total foi extraída e utilizada para a análise da expressão protéica de Ang I/II e do receptor AT1, através da técnica de Western Blotting. Para a análise da expressão gênica do receptor AT1, realizou-se a extração do RNA total, e em seguida a técnica de RT-PCR em Tempo Real.

\subsection{Citometria de Fluxo}

A quantificação de células transfectadas foi determinada através da análise em Citômetro de Fluxo (Personal Cell Analysis - Guava Technologies Inc). Assim, 24 horas após a transfecção com RNAi controle positivo, o meio de cultura foi descartado, as células lavadas com PBS 1X e descoladas do fundo da placa com a utilização de tripsina. Posteriormente, as células foram coletadas e centrifugadas a $1400 \mathrm{rpm}$ por $5 \mathrm{~min}$. O sobrenadante foi desprezado e o pellet de 
células ressuspendido em PBS 1X. Em cada experimento analisou-se 5000 células/well, em duplicata. Os resultados são expressos em porcentagem.

\subsection{Análise da Expressão Gênica - RT-PCR em Tempo Real}

\subsubsection{Extração do RNA total e cDNA}

O RNA total das amostras foi extraído utilizando-se o reagente Trizol (Invitrogen), de acordo com as especificações do fabricante. Ao término deste processo, o pellet de RNA foi diluído em água DEPC e homogeneizado. Em seguida, as amostras foram dosadas no espectrofotômetro, em comprimento de onda de $260 \mathrm{~nm}$ e $280 \mathrm{~nm}$. Após a quantificação do RNA total, realizou-se uma eletroforese para a verificação da integridade do RNA total extraído, em gel de agarose $1 \%$ a 90 Volts, corado com brometo de etídio. Em seguida, realizou-se a reação de transcrição reversa para a síntese de uma fita de DNA complementar (cDNA) ao RNAm a partir de $1 \mu \mathrm{g}$ de RNA total, de acordo com as especificações fornecidas pelo fabricante da enzima (M-MLV Reverse Transcriptase, Invitrogen) em termociclador (MJ Research - PTC 200).

\subsubsection{PCR em Tempo Real}

Após a transfecção das culturas de cardiomiócitos com o RNAi torna-se necessária a confirmação da eficiência do silenciamento gênico. Como o RNAi exerce seu efeito no nível do RNAm, é necessário monitorar os níveis de RNAm do gene em questão. A análise da expressão gênica do receptor AT1 nas células transfectadas com RNAi para AT1 foi realizada por PCR em Tempo Real. Paralelamente, também analisamos a expressão gênica de ANF e $\alpha$-actina esquelética, os quais são utilizados como marcadores de hipertrofia cardíaca.

Com base no $\mathrm{Ct}$, o qual representa a linha de base de detecção de fluorescência, correspondente à fase exponencial, é possível estimar a quantidade inicial de cDNA aplicado nas diferentes amostras (BUSTIN, 2002). A expressão gênica é determinada através da fórmula: $2^{-}$ $\Delta \Delta \mathrm{Ct}$, onde $\Delta \Delta \mathrm{Ct}=[\mathrm{Ct}$ amostra $-\mathrm{Ct} \beta$-actina da mesma amostra $]-[\mathrm{Ct}$ controle $-\mathrm{Ct} \beta$-actina controle]. Os resultados obtidos foram expressos com base na relação do RNAm de cada gene de 
interesse com os níveis de RNAm da $\beta$-actina. A $\beta$-actina foi selecionada uma vez que a sua expressão não é alterada na hipertrofia cardiomiocítica induzida pelo HT (CARNEIRO-RAMOS et al., 2004). Paralelamente à análise da expressão da $\beta$-actina realizou-se também a análise da expressão da ciclofilina. É importante ressaltar que a expressão da $\beta$-actina e da ciclofilina não foi alterada pelo tratamento com $\mathrm{T}_{3}$ (dados não mostrados). Para todos os genes investigados foram realizadas curvas de quantidades progressivas de cDNA e primers. As amostras foram processadas em triplicata ( $\mathrm{n}=3 /$ grupo experimental) e em 2 experimentos independentes. Após a padronização dos diferentes primers, foram escolhidas as concentrações ideais de cDNA para cada primer, com o objetivo de que não houvesse saturação de amostra durante a reação. Para cada reação foi também utilizado um controle negativo, em duplicata, o qual não continha cDNA. As reações foram realizadas utilizando $300 \eta \mathrm{M}$ de cada primer, cDNA, $\mathrm{H}_{2} \mathrm{O}$ DEPC e $6.25 \mu 1$ de SYBR Green PCR Master Mix (Applied Biosystems), em um volume final de $12.5 \mu 1 /$ reação. As reações foram realizadas utilizando-se 40 ciclos e temperatura de anelamento de $60{ }^{\circ} \mathrm{C}$. As sequências dos primers utilizados encontram-se descritas na tabela a seguir (Tabela 1):

Tabela 1- Sequências dos primers utilizados para a análise da expressão gênica por PCR em Tempo Real.

\begin{tabular}{|c|c|c|}
\hline $\begin{array}{c}\text { Genes } \\
\text { analisados }\end{array}$ & $\begin{array}{l}\text { Pares de } \\
\text { Base }\end{array}$ & Sequências dos iniciadores \\
\hline$\beta$ actina & $60 \mathrm{bp}$ & $\begin{array}{c}\text { 5'- AGT TCG CCA TGG ATG ACG AT -3' } \\
\text { 5'-AAG CCG GCC TTG CAC AT-3' }\end{array}$ \\
\hline $\mathbf{A T}_{1}$ & $121 \mathrm{bp}$ & $\begin{array}{c}\text { 5'- CAC TTT CCT GGA TGT GCT GA -3' 5' - CCC AGA } \\
\text { AAG CCG TAG AAC A -3' }\end{array}$ \\
\hline $\mathbf{A N F}$ & $111 \mathrm{bp}$ & $\begin{array}{l}\text { 5'- AGT GCG GTG TCC AAC ACA G -3' } \\
\text { 5'- CTT CAT CGG TCT GCT CGC T -3' }\end{array}$ \\
\hline $\begin{array}{c}\alpha \text {-actina } \\
\text { esquelética }\end{array}$ & $77 \mathrm{pb}$ & $\begin{array}{l}\text { 5'- CCT GCC ACA CGC CAT CAT -3' } \\
\text { 5'- GCT CGG TGA GGA TTT TCA TCA G -3' }\end{array}$ \\
\hline
\end{tabular}

\subsection{Análise da Expressão Protéica - Western Blotting}


Para avaliar a expressão protéica do receptor AT1, bem como a expressão da Akt, GSK3$\beta$ e mTOR extraiu-se a proteína total das células, utilizando um tampão de lise (90 mM KCl, 10 $\mathrm{mM}$ Hepes, $3 \mathrm{mM} \mathrm{MgCl}{ }^{2+}, 5 \mathrm{mM}$ EDTA, glicerol $1 \%, 1 \mathrm{mM}$ DTT, $0.04 \%$ SDS, $20 \mathrm{mM}$ aprotinina, $20 \mathrm{mM}$ pepstatina, $20 \mathrm{mM}$ leupepstatina, $40 \mu \mathrm{M}$ PMSF e $100 \mathrm{mM}$ ortovanadato). A concentração protéica das amostras foi obtida pelo método de Bradford (BRADFORD, 1976). Em seguida, 70 ug de proteína total foram submetidas à eletroforese em gel denaturante de poliacrilamida (5 \% stacking/6 ou $10 \%$ gel de resolução) e transferidas para membrana de nitrocelulose (Bio Rad). Esta foi corada com solução Ponceau para avaliar se a concentração de proteína era similar entre as amostras. Em seguida a membrana foi incubada com solução de TBST (50 mM Tris, $150 \mathrm{mM} \mathrm{NaCl}, \mathrm{pH} 7.5$ and Tween-20 $2 \%$ ) por $10 \mathrm{~min}$. Posteriormente, a membrana foi incubada com um dos anticorpos primários, descritos na tabela 2 , em agitação, por cerca de 14 horas, a $4{ }^{\circ} \mathrm{C}$. Após a sua lavagem, esta foi incubada com anticorpo secundário antigoat, anti-rabbit ou anti-mouse IgG conjugado à peroxidase (Jackson Immuno Research). A membrana foi lavada novamente e então incubada com solução de ECL (Amersham Biosciences), a qual tem como função promover uma reação de luminescência, cujo produto final irá impressionar um filme de raio X. A banda, ou bandas, correspondente à proteína de interesse foi quantificada por densitometria, em um sistema de fotodocumentação Gel Pro Imager (Media Cybernetics), sendo os valores expressos em porcentagem ou em vezes de indução em relação ao controle. Além disso, a análise de $\alpha$-actinina foi utilizada em todos os experimentos como controle da concentração de proteína das diferentes amostras. Os diferentes anticorpos utilizados encontram-se descritos na tabela a seguir (Tabela 2): 
Tabela 2 - Lista de anticorpos primários utilizados para a análise de expressão protéica por Western blotting.

\begin{tabular}{|c|c|c|c|}
\hline $\begin{array}{c}\text { Proteínas } \\
\text { Analisadas }\end{array}$ & Origem & $\begin{array}{c}\text { Peso } \\
\text { Molecular }\end{array}$ & Titulação \\
\hline $\mathbf{A T}_{1}$ & Santa Cruz (SC-1173) & $47-52 \mathrm{kDa}$ & $1: 500$ \\
\hline $\mathbf{A T _ { 2 }}$ & Santa Cruz (SC-7420) & $44 \mathrm{kDa}$ & $1: 500$ \\
\hline AKT total & Santa Cruz (sc-7126) & $70 \mathrm{kDa}$ & $1: 1000$ \\
\hline AKT-p $\left(\operatorname{Ser}^{473}\right)$ & Santa Cruz (SC-7985R) & $70 \mathrm{kDa}$ & $1: 700$ \\
\hline AKT-p $\left(\mathrm{Thr}^{308}\right)$ & Santa Cruz (SC-7985R) & $70 \mathrm{kDa}$ & $1: 500$ \\
\hline GSK3 $\beta$ total & Cell Signaling (9166) & $45 \mathrm{kDa}$ & $1: 1000$ \\
\hline GSK3 $\beta-p\left(\right.$ Ser $\left.^{9}\right)$ & Cell Signaling (9336S) & $45 \mathrm{kDa}$ & $1: 400$ \\
\hline$\alpha$ actinina & Santa Cruz (SC-15335) & $100 \mathrm{kDa}$ & $1: 1000$ \\
\hline mTOR total & Cell Signaling (2972) & $289 \mathrm{kDa}$ & $1: 500$ \\
\hline mTOR-p (Ser2448) & Cell Signaling (2971S) & $289 \mathrm{kDa}$ & $1: 500$ \\
\hline
\end{tabular}

\subsection{Ensaio de Incorporação de Leucina Triciada}

Após o plaquemanento, as células foram mantidas em meio de crescimento por 3 dias e então foram submetidas a meio contendo $0,5 \%$ de NCS por 18 horas. Em seguida, as células foram tratadas por 24 horas com meio sem soro (controle) ou meio sem soro suplementado com $10 \eta \mathrm{M}$ de $\mathrm{T}_{3}\left(\mathrm{~T}_{3}\right)$. Seis horas antes do término do tratamento, o meio foi retirado e novo meio contendo $5 \mu \mathrm{Ci} / \mathrm{ml}$ de L-[4,5- $\left.{ }^{3} \mathrm{H}\right]$ Leucina (GE Healthcare) foi adicionado às células para avaliar a incorporação do aminoácido em proteínas que estão sendo sintetizadas pelas células. Ao final do tratamento, o meio foi descartado, as células foram lavadas com PBS1X e foram lisadas com $500 \mu \mathrm{l}$ de ácido tricloroacético (TCA) 10\%. O homogenato foi coletado e centrifugado a $4{ }^{\circ} \mathrm{C}$, por $10 \mathrm{~min}$, a $14000 \mathrm{rpm}$. Após a centrifugação, o sobrenadante foi desprezado, o pellet ressuspendido novamente em $500 \mu \mathrm{l}$ de TCA e submetido novamente a centrifugação. O pellet final foi dissolvido em $500 \mu \mathrm{lde} \mathrm{NaOH} 0,2 \mathrm{~N}$ e as amostras foram então incubadas a $60{ }^{\circ} \mathrm{C}$ por 30 min. Em seguida, em um tubo de cintilação acrescentou-se $400 \mu 1$ da amostra e 3,6 ml do líquido de cintilação (Perkin Elmer). As amostras foram analisadas em Cintilador (Liquid Scintillator Analyzer TRI-CARB 2100TR, Packard) para a quantificação da incorporação de 
leucina triciada em cada amostra. A incorporação do aminoácido marcado das amostras foi então normalizada pelo número total de células. Os resultados são expressos em porcentagem.

\subsection{HPLC}

Os níveis de Ang I e Ang II no meio de cultura dos cardiomiócitos foram analisados por cromatografia líquida de alta eficiência (HPLC) no Departamento de Fisiologia da Universidade Federal de São Paulo. As células foram tratadas com meio sem soro, nas células controle, ou meio sem soro contendo $\mathrm{T}_{3}(10 \eta \mathrm{M})$ por 24 horas. Após o tratamento, coletou-se rapidamente o meio de cultura das células. Em seguida, os peptídeos de interesse foram extraídos do meio de cultura e purificados em colunas Sep-Pak-C18 (Waters Corporation, Milford, MA), de acordo com um método estabelecido previamente (FRANCO MDO et al., 2003). Após isso, 100 ul de cada amostra foram filtrados e injetados em uma coluna analítica do sistema de HPLC. Os peptídeos foram analisados por HPLC de fase reversa usando uma coluna Aquapore ODS 300 (7 $\mu \mathrm{m}, 4.6 \times 250 \mathrm{~mm}$; Applied Biosystems) equilibrada com 0.1\% de ácido fosfórico contendo 5\% (vol/vol) de acetonitrile. Os peptídeos de Angiotensina foram separados por eluição isocrática por 5 min, seguido por $20 \mathrm{~min}$ em gradiente linear (5-35\%) de acetonitrile em $0.1 \%$ (vol/vol) de ácido fosfórico em baixo fluxo $(1.5 \mathrm{ml} / \mathrm{min})$. O perfil cromatográfico de cada amostra foi comparado com o obtido de peptídeos padrão do SRA (Sigma) em absorbância de 214 nm. Os níveis dos peptídeos foram normalizados pelo número total de células, e os resultados são expressos em ng do peptídeo/ml/número de células (ALMEIDA et al., 2006).

\subsection{Análise dos Resultados}

Os resultados obtidos são apresentados como média \pm desvio-padrão da média e são expressos em porcentagem de variação em relação ao grupo controle (100\%), ou em vezes de indução em relação ao grupo controle (neste caso considerando este grupo tendo o valor de 1). $\mathrm{O}$ "n" representa o número de experimentos realizados com diferentes culturas de cardiomiócitos, sendo que em cada experimento eram utilizadas no mínimo três amostras (triplicatas). Os dados foram analisados e comparados utilizando-se a Análise de Variância de uma via (one-way ANOVA), seguido do pós-teste de Tukey para as análises entre grupos. O teste $\mathrm{t}$ de Student foi 
utilizado para comparação entre dois grupos (controle e tratado). A diferença estatisticamente significante foi definida pelos valores de $p<0,05$. 


\section{RESULTADOS}

Parte dos resultados apresentados a seguir fazem parte de um trabalho recentemente publicado no periódico Basic Research in Cardiology (DINIZ et al., 2009), conforme consta no ANEXO B .

\subsection{Caracterização das culturas primárias de cardiomiócitos por imunocitoquímica}

Inicialmente, as culturas primárias de cardiomiócitos foram caracterizadas fenotipicamente, através de imunocitoquímica para tropomiosina sarcomérica, uma proteína específica de cardiomiócitos (Figura 4A). A análise da figura abaixo evidencia a morfologia típica destas células em cultura, as quais se apresentam alongadas e com prolongamentos citoplasmáticos. As culturas de cardiomiócitos não apresentaram marcação para vimentina, uma proteína específica para fibroblastos, indicando o alto grau de pureza das mesmas (Figura 4B).

A

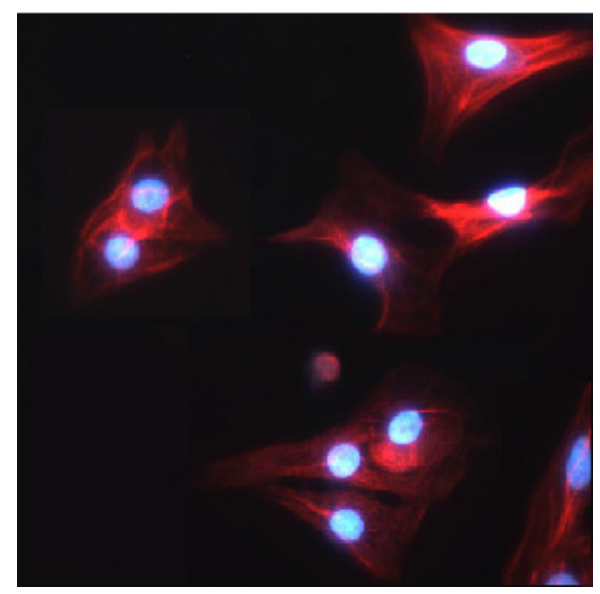

B

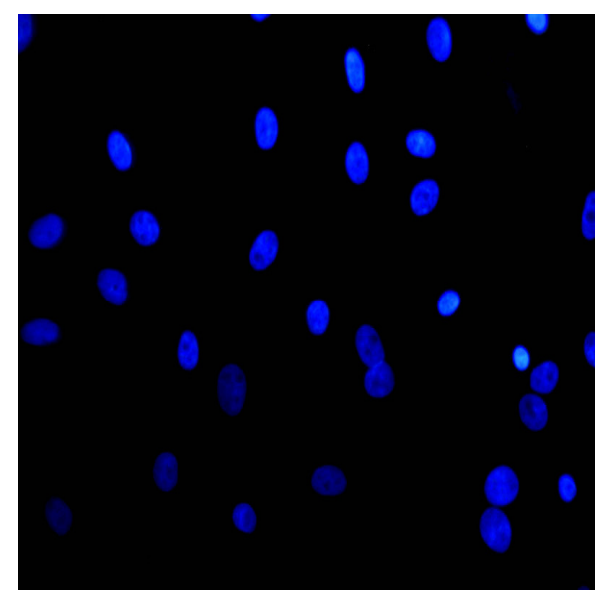

Figura 4- Análise das culturas primárias de cardiomiócitos através de imunocitoquímica para tropomiosina sarcomérica (A) e para vimentina (B) em microscópio de fluorescência. O núcleo (azul) foi corado com DAPI. Aumento de 40x. 
5.2 Avaliação da eficiência da transfecção das culturas primárias de cardiomiócitos Utilização de um RNAi controle positivo

Para avaliar o número de células transfectadas com RNAi, as células foram inicialmente transfectadas com RNAi controle positivo e foram então analisadas após 24 horas em microscópio confocal (Figura 5 A,B) ou por citometria de fluxo (Figura 5 C,D,E). Os resultados obtidos nesta primeira etapa são apresentados a seguir.
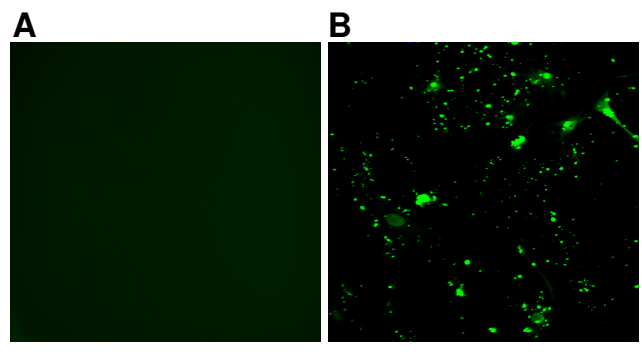

C

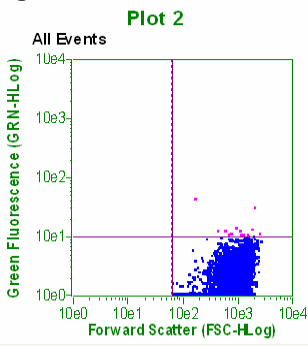

D

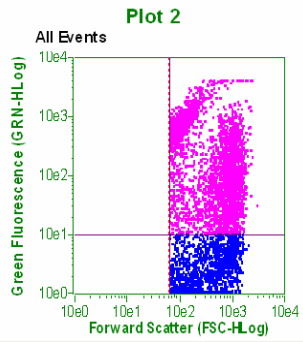

E

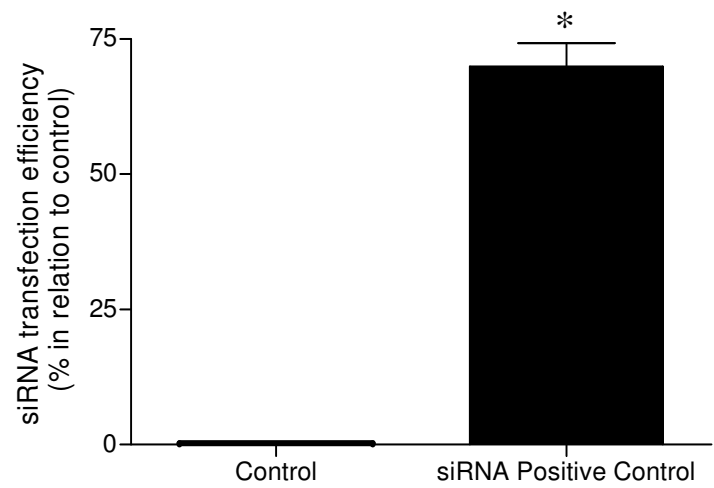

Figura 5- Análise da eficiência de transfecção das culturas primárias de cardiomiócitos em células controle $(A, C)$ ou em células transfectadas com $50 \eta \mathrm{M}$ de RNAi controle positivo (B,D) após 24 horas. As células foram avaliadas por microscopia confocal (A,B) ou por citometria de fluxo (C,D). quantificação da eficiência da transfecção das células por citometria de fluxo é demonstrada em porcentagem (E). $* P<0.01$ vs. controle $(\mathrm{n}=3)$.

A análise dos dados apresentados na figura anterior demonstra que mais de $70 \%$ das células foram eficientemente transfectadas com o RNAi controle positivo após 24 horas. 


\subsection{Avaliação da eficiência do silenciamento do receptor AT1- Utilização de RNAi para receptor AT1}

Para avaliarmos qual seria a melhor sequência de RNAi capaz de induzir o máximo silenciamento do receptor AT1, utilizamos inicialmente três sequências distintas de RNAi, as quais apresentam diferentes conteúdos de G/C. Para isso, as células foram transfectadas com essas três sequências de RNAi para AT1 por 24 ou 48 horas, e o silenciamento do receptor AT1 foi inicialmente avaliado por expressão gênica, através do RT-PCR em Tempo Real (Figura 6).

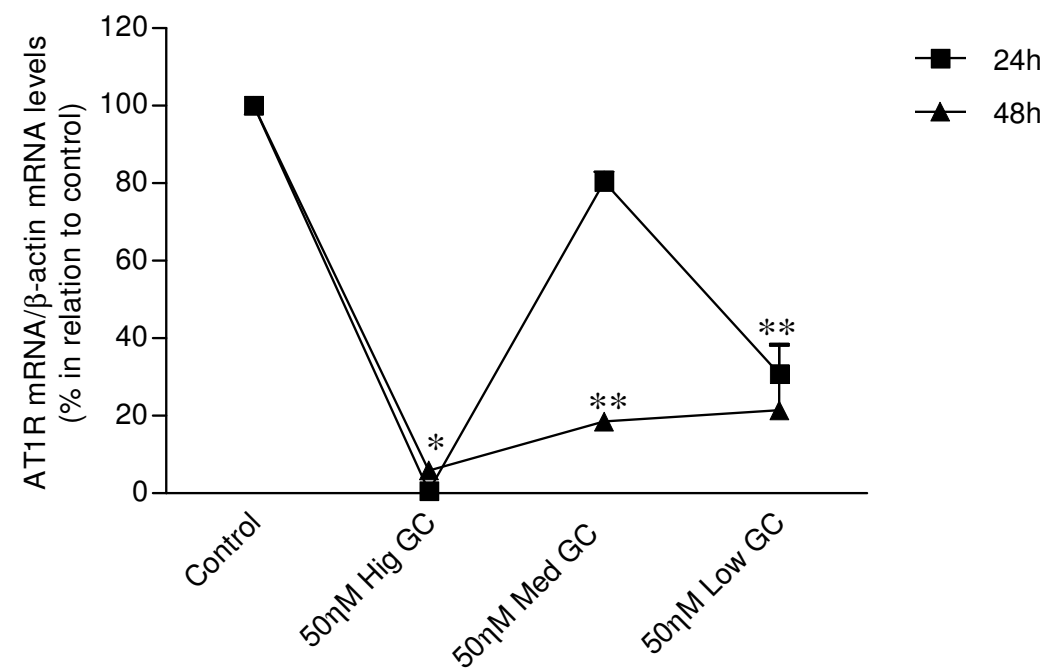

Figura 6- Análise da expressão gênica do receptor AT1 em cardiomiócitos transfectados com 50 ๆM de RNAi para AT1 com alto (Hig), médio (Med) ou baixo (Low) conteúdo de G/C por 24 ou 48 horas, avaliada por PCR em Tempo Real. Os valores são expressos em porcentagem. $* P<0.001$ vs. controle; $* * P<0.01$ vs. controle $(n=3)$.

As células transfectadas com a sequência de RNAi com alto (High) conteúdo de G/C apresentaram uma redução significativa dos níveis do RNAm do receptor AT1 após 24 e 48 horas, a qual foi mais acentuada do que a redução promovida pelas sequências de RNAi com médio ou baixo conteúdo de G/C.

Em seguida, analisamos a expressão protéica do receptor AT1, por Western Blotting, nas células transfectadas com as três diferentes sequências de RNAi (Figura 7). 


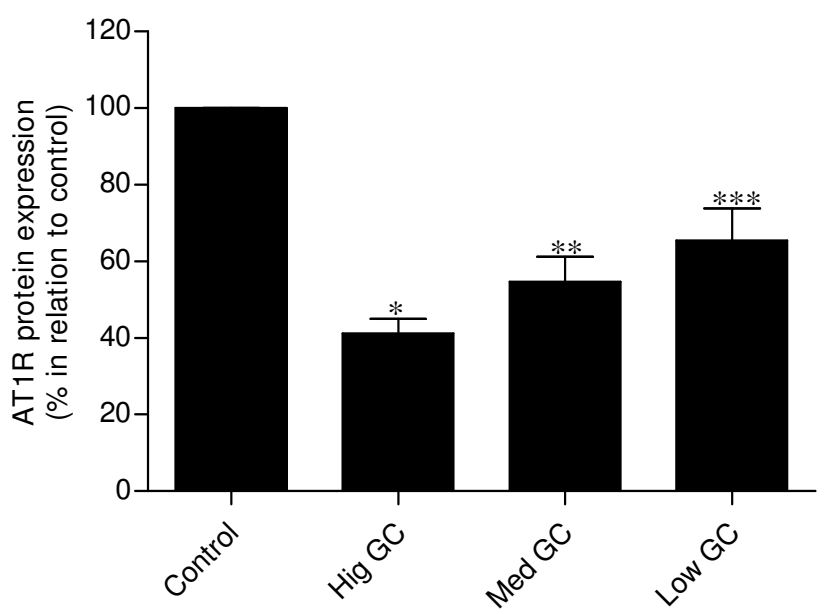

Figura 7- Análise da expressão protéica do receptor AT1 em cardiomiócitos transfectados com 50 ๆM de RNAi para AT1 com alto (Hig), médio (Med) ou baixo (Low) conteúdo de G/C por 72 horas, avaliada por Western Blotting. Os valores são expressos em porcentagem. $* \mathrm{P}<0.001$ vs. controle; $* * \mathrm{P}<0.01$ vs. controle; *** $\mathrm{P}<0.05(\mathrm{n}=3)$.

As células transfectadas com a sequência de RNAi com alto (High) conteúdo de G/C por 72 horas apresentaram uma redução significativa dos níveis de expressão protéica do receptor AT1, a qual também foi mais acentuada do que a redução promovida pelas sequências de RNAi com médio ou baixo conteúdo de G/C.

Esses resultados nos direcionaram a utilizar a sequência de RNAi com alto conteúdo de G/C para induzir o silenciamento do receptor AT1 nas culturas de cardiomiócitos nos demais experimentos. Com o intuito de avaliar a partir de que momento o silenciamento do receptor AT1 era obtido, e por quanto tempo este silenciamento era mantido, outros grupos de células foram transfectados para as análises da expressão gênica (Figura 8 A) e protéica (Figura 8 B) do receptor AT1. 

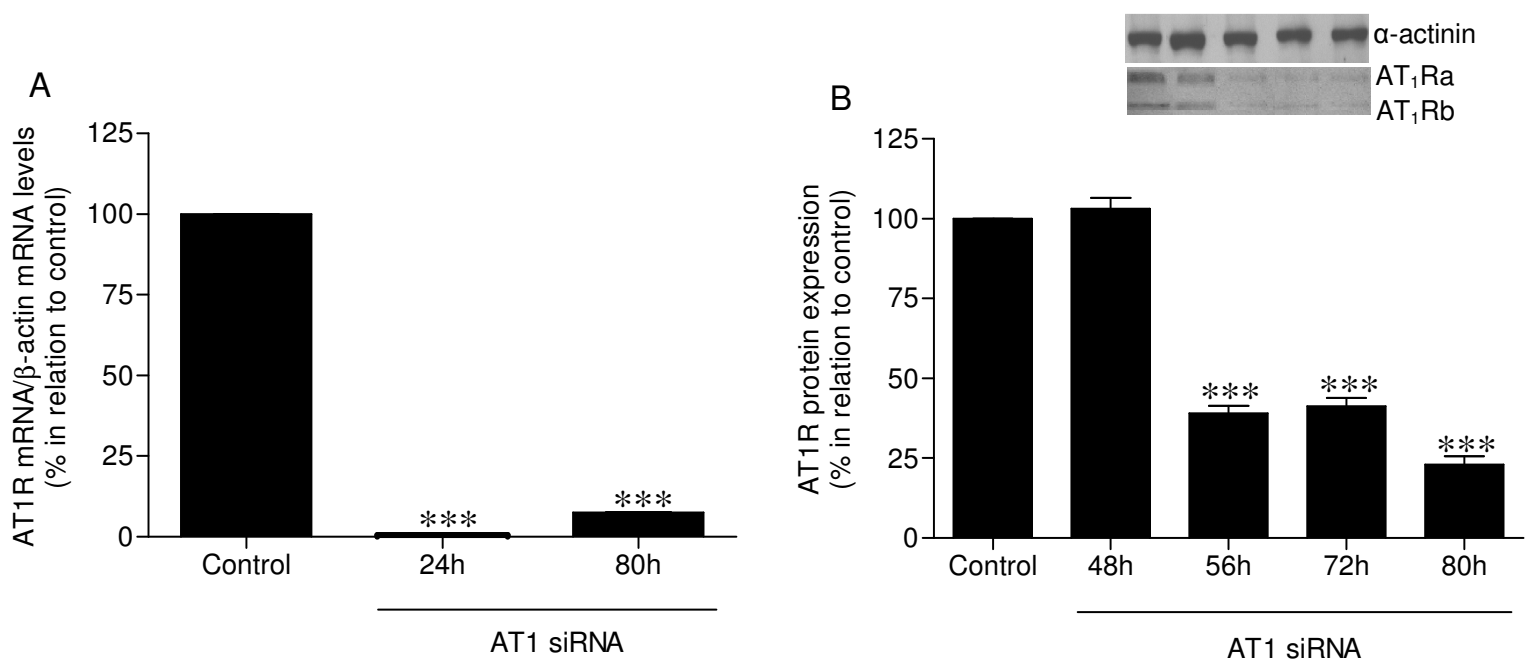

Figura 8- Análise da expressão gênica (A) e protéica (B) do receptor AT1 em cardiomiócitos transfectados com $50 \eta$ M de RNAi para AT1 (High GC) por 24, 48, 56, 72 ou 80 horas, avaliadas respectivamente por PCR em Tempo Real e por Western Blotting. Os valores são expressos em porcentagem. $* P<0.001$ vs. controle; $* * * P<0.001$ vs. controle $(\mathrm{n}=3)$.

As células transfectadas com RNAi para AT1 por 24 horas apresentaram uma diminuição significativa da expressão gênica do receptor AT1, a qual se manteve até 80 horas após a transfecção. No mesmo sentido, as células transfectadas com RNAi para AT1 por 56 horas apresentaram uma redução significativa dos níveis protéicos do receptor AT1, a qual foi mantida até 80 horas após a transfecção.

Paralelamente, avaliamos também se o silenciamento do receptor AT1, promovido por RNAi, poderia alterar a expressão do receptor AT2 (Figura 9).
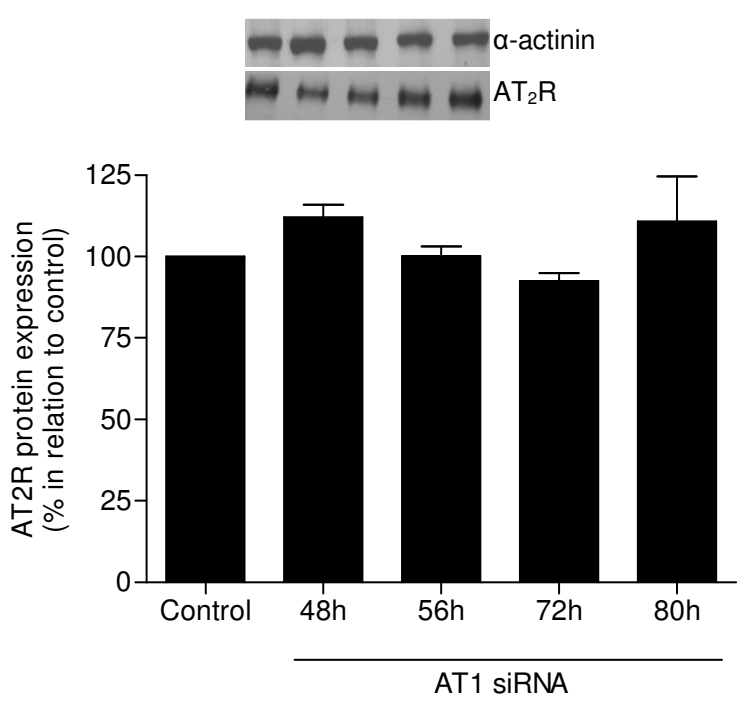

Figura 9- Análise da expressão protéica do receptor AT2 em culturas primárias de cardiomiócitos transfectadas com $50 \eta$ M de RNAi para AT1 (High GC) por 48, 56, 72 ou 80 horas, avaliada por Western Blotting. Os valores são expressos em porcentagem $(n=3)$. 
De acordo com os resultados demonstrados anteriormente podemos observar que a transfecção das células com RNAi para AT1 não foi capaz de alterar os níveis de expressão protéica do receptor AT2 nas culturas de cardiomiócitos.

\subsection{Avaliação do efeito da transfecção na expressão do receptor AT1 - Utilização de um RNAi controle negativo (Scramble RNAi)}

Para avaliarmos se o processo de transfecção das culturas de cardiomiócitos poderia alterar a expressão protéica do receptor AT1 de maneira não-específica, independentemente da sequência, utilizamos também um RNAi controle negativo, o qual é incapaz de reconhecer transcritos produzidos pelas células. Para isso, as células foram transfectadas com RNAi controle negativo por 56, 72 ou 80 horas, e em seguida avaliamos então a expressão do receptor AT1 por Western Blotting. Os dados referentes a estes experimentos encontram-se descritos a seguir (Figura 10):

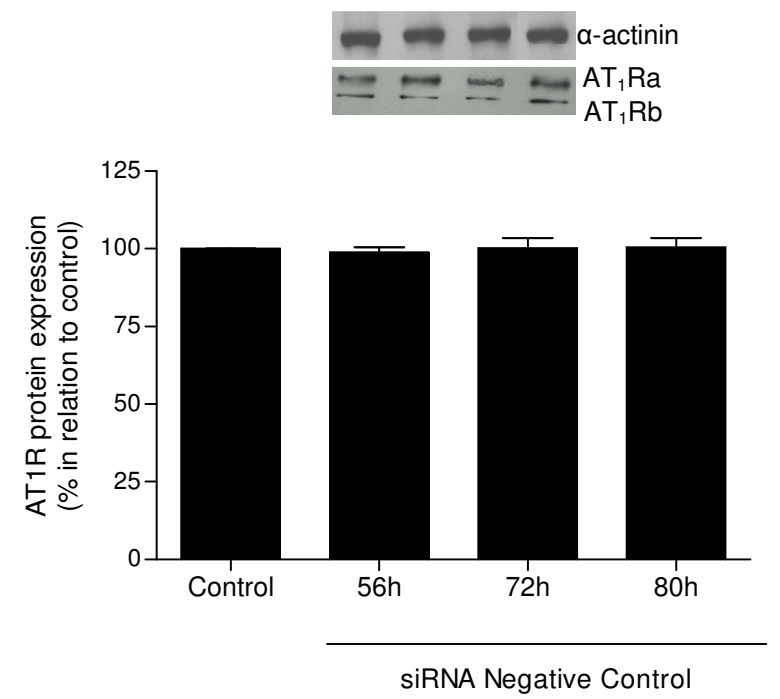

Figura 10- Análise da expressão protéica do receptor AT1 em culturas primárias de cardiomiócitos transfectadas com RNAi controle negativo por Western Blotting. As células foram transfectadas com 50ๆM de RNAi controle negativo por 56, 72 ou 80 horas. Os valores são expressos em porcentagem $(n=3)$.

Estes resultados demonstram que a transfecção das culturas primárias de cardiomiócitos com RNAi controle negativo não foi capaz de alterar a expressão do receptor AT1, confirmando portanto que o silenciamento do receptor AT1 por RNAi é dependente da sequência empregada, e independente do processo de transfecção. 


\subsection{Avaliação da contribuição do receptor AT1 para a hipertrofia induzida pelo $\mathbf{T}_{3}$}

Após a padronização do silenciamento do receptor AT1 por RNAi, iniciamos então a análise da possível participação deste receptor no processo de hipertrofia dos cardiomiócitos promovido pelo $T_{3}$. A avaliação da hipertrofia foi realizada através da análise da expressão gênica de dois marcadores de hipertrofia cardíaca, o ANF (Figura 11 A) e a $\alpha$-actina esquelética (Figura $11 \mathrm{~B}$ ), através da técnica de RT-PCR em Tempo Real, associada à análise de síntese protéica, através do ensaio de incorporação de leucina triciada (Figura $11 \mathrm{C}$ ). Ainda, para validar os resultados obtidos com o silenciamento do receptor AT1, utilizamos também um bloqueador farmacológico deste receptor (Losartan). Os resultados dessas análises encontram-se a seguir:

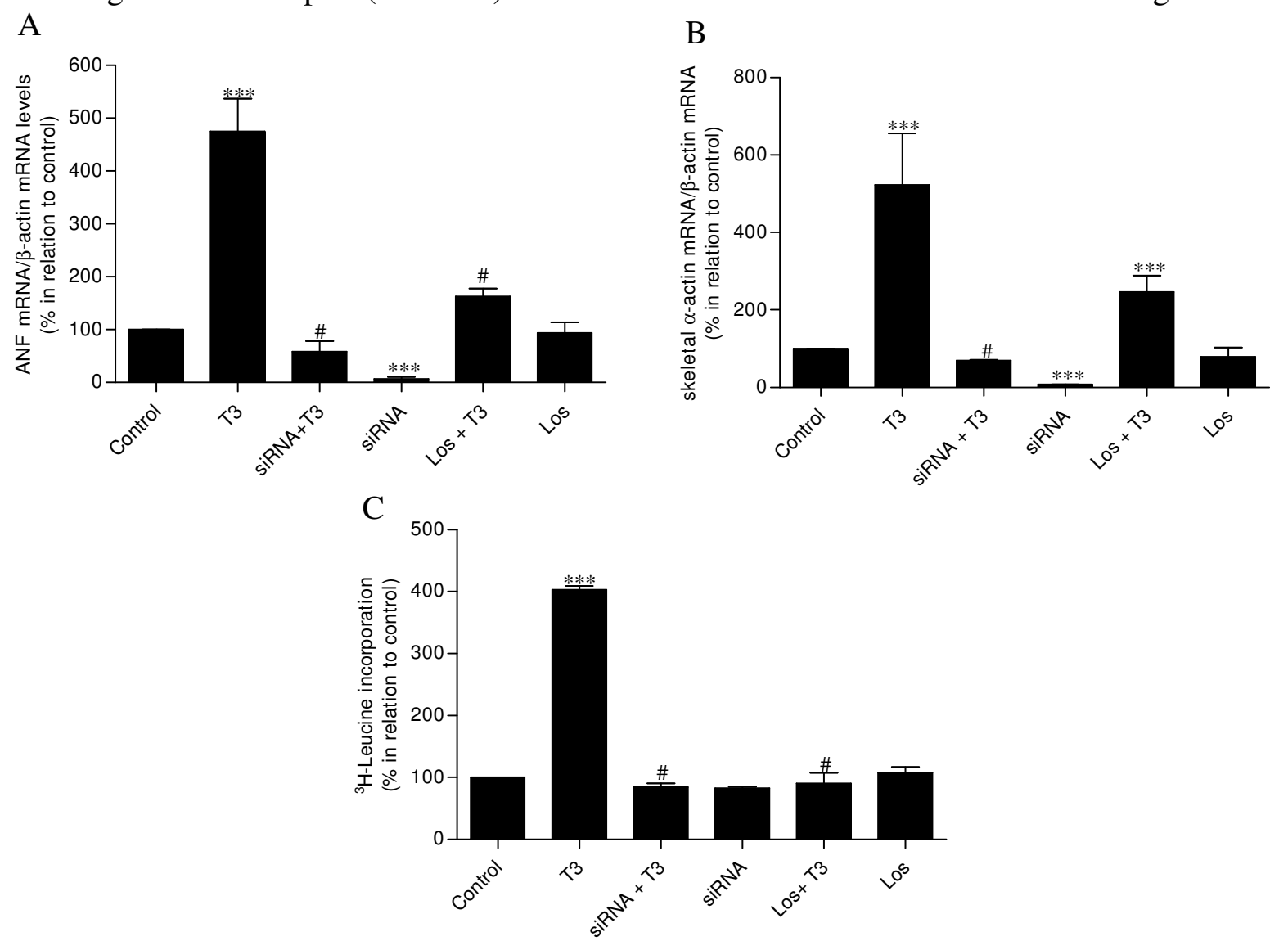

Figura 11- Análise da expressão gênica de ANF (A) e $\alpha$-actina esquelética (B) avaliada por RT-PCR em Tempo Real, em células tratadas com meio sem soro contendo $10 \eta \mathrm{M}$ de $T_{3}$ por 24 horas $\left(T_{3}\right)$ ou em células transfectadas com $50 \eta \mathrm{M}$ de RNAi para AT1 por 56 horas e tratadas com $10 \eta \mathrm{M}$ de $\mathrm{T}_{3}$ por 24 horas ( $\operatorname{siRNA}+\mathrm{T}_{3}$ ), células transfectadas com $50 \eta \mathrm{M}$ de RNAi para receptor AT1 por 80 horas (siRNA), células tratadas com $1 \mu \mathrm{M}$ de Losartan e $10 \eta \mathrm{M}$ de $\mathrm{T}_{3}$ (Los $+\mathrm{T}_{3}$ ), células tratadas com $1 \mu \mathrm{M}$ de Los por 24 horas ou somente meio sem soro (controle). Ensaio de incorporação de leucina triciada (C) nos grupos controle, $\mathrm{T}_{3}$, siRNA+T $\mathrm{T}_{3}$, siRNA, Los $+\mathrm{T}_{3}$ e Los. Os resultados são expressos em porcentagem. $* * * P<0.001$ vs. controle; $\# P<0.01$ vs. $\mathrm{T}_{3}(\mathrm{n}=3)$. 
Como esperado, as células tratadas com $\mathrm{T}_{3}$ apresentaram um aumento significativo nos níveis de expressão gênica de ANF e $\alpha$-actina esquelética (Figura 11 A,B) confirmando, portanto, o estado hipertrófico destas células após tratamento com $\mathrm{T}_{3}$. Entretanto, o silenciamento do receptor AT1 por RNAi ou o bloqueio farmacológico deste receptor foram capazes de prevenir ou atenuar o aumento nos níveis de ANF e $\alpha$-actina esquelética induzido pelo $\mathrm{T}_{3}$. Além disso, as células transfectadas com RNAi para AT1 apresentaram uma diminuição significativa tanto nos níveis de ANF como também nos níveis de $\alpha$-actina esquelética.

$\mathrm{O}$ ensaio de incorporação de leucina triciada demonstrou que as células tratadas com $\mathrm{T}_{3}$ apresentaram um aumento significativo da síntese protéica (Figura 11C). Entretanto, o silenciamento do receptor AT1 por RNAi ou o bloqueio farmacológico deste receptor preveniram totalmente o aumento da incorporação de leucina induzida pelo $\mathrm{T}_{3}$.

Os resultados obtidos da análise da expressão gênica de ANF e $\alpha$-actina esquelética, associados à análise de síntese protéica, evidenciam que o receptor AT1 é fundamental para o efeito hipertrófico exercido pelo $\mathrm{T}_{3}$ nas culturas primárias de cardiomiócitos.

\subsection{Avaliação da participação do receptor AT1 para a ativação da via de sinalização da Akt/GSK3- $\beta /$ mTOR induzida pelo $T_{3}$}

Recentemente demonstrou-se que a via da PI3K/Akt/mTOR é recrutada para o desenvolvimento da hipertrofia cardíaca induzida pelo HT in vivo (KUZMAN et al., 2007) e in vitro (KENESSEY e OJAMAA, 2006). Considerando que o silenciamento do receptor AT1, ou o bloqueio farmacológico deste receptor, foi capaz de prevenir o desenvolvimento da hipertrofia dos cardiomiócitos promovida pelo $\mathrm{T}_{3}$, avaliamos então se o receptor AT1 poderia atuar como um mediador da ativação dessa via. Para avaliar o efeito do $T_{3}$ na modulação da via Akt/GSK3$\beta / \mathrm{mTOR}$, os cardiomiócitos foram submetidos ao tratamento com $\mathrm{T}_{3}$ por diferentes tempos $(5,10$, 15 e 30 min ou 24 horas). Em seguida, para avaliarmos a possível contribuição do receptor AT1 para a ativação desta via de sinalização utilizamos células transfectadas com RNAi para AT1, ou células pré-tratadas com Losartan, as quais foram então submetidas ao tratamento com $T_{3}$. As análises dos níveis de Akt fosforilada, Akt total e razão Akt fosforilada/Akt total nas culturas de cardiomiócitos controle (Figura 12 A,B,C), nas culturas de cardiomiócitos transfectadas com 
RNAi para AT1 (Figura 12 D,E,F) e nas culturas pré-tratadas com Losartan, submetidas ao tratamento com $\mathrm{T}_{3}$ (Figura $12 \mathrm{G}, \mathrm{H}, \mathrm{I}$ ), encontram-se a seguir.

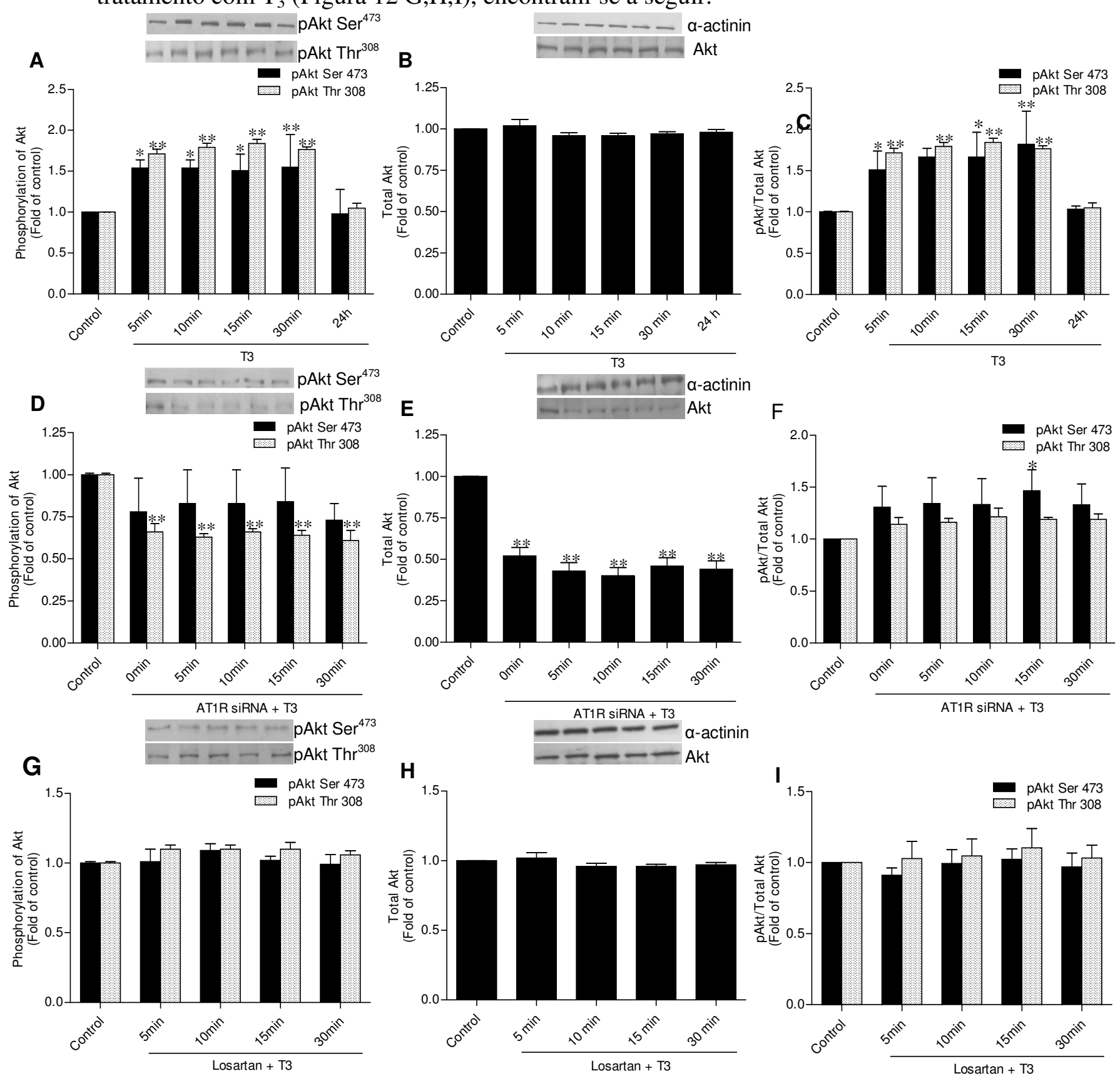

Figura 12- Análise dos níveis de Akt fosforilada na $\operatorname{Ser}^{473}$ e na $\operatorname{Thr}^{308}$ (A), Akt total (B) e razão Akt fosforilada na Ser ${ }^{473}$ e na Thr ${ }^{308} / \mathrm{Akt}$ total (C) avaliada por Western Blotting, em células tratadas com meio sem soro contendo $10 \eta \mathrm{M}$ de $\mathrm{T}_{3}$ por $5,10,15,30 \mathrm{~min}$ ou 24 horas, ou meio sem soro nas células controle. Análise dos níveis de Akt fosforilada na $\operatorname{Ser}^{473}$ e na $\operatorname{Thr}^{308}$ (D), Akt total (E) e razão Akt fosforilada na Ser ${ }^{473}$

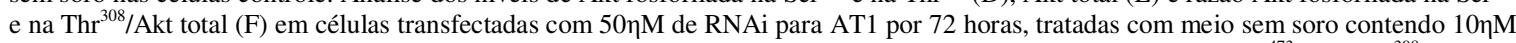
de $T_{3}$ por 5, 10, 15 ou 30 min, ou meio sem soro nas células controle. Análise dos níveis de Akt fosforilada na $\operatorname{Ser}^{473}$ e na Thr ${ }^{308}(\mathrm{G})$, Akt total $(\mathrm{H})$ e razão Akt fosforilada na $\mathrm{Ser}^{473}$ e na Thr ${ }^{308} / \mathrm{Akt}$ total (I) em células tratadas com meio sem soro contendo $1 \mu \mathrm{M}$ de Losartan (Los) por 30 min, e então tratadas com meio sem soro contendo $10 \eta \mathrm{M}$ de $\mathrm{T}_{3}$ por 5, 10, 15 ou 30 min, ou meio sem soro nas células controle. Expressão da $\alpha$-actinina foi usada para normalização. Os valores são representados como vezes de indução em relação às células controle. $* P<0.05$ vs. controle; $* * P<0.01$ vs. controle $(\mathrm{n}=4)$. 
Os níveis de Akt fosforilada (Figura 12A) e a razão Akt fosforilada/Akt total (Figura 12C) aumentaram rapidamente após tratamento com $\mathrm{T}_{3}$. No entanto, as células transfectadas com RNAi para AT1 submetidas ao tratamento com $T_{3}$ apresentaram uma redução significativa nos níveis de Akt fosforilada na Thr 308 (Figura 12D). No mesmo sentido, as células transfectadas com RNAi para AT1 apresentaram uma diminuição significativa nos níveis de Akt total (Figura 12E). As análises dos níveis de Akt fosforilada (Figura 12D) e da razão Akt fosforilada/Akt total (Figura 12F) evidenciaram que as células transfectadas com RNAi para AT1 apresentaram uma atenuação da ativação da Akt induzida pelo $\mathrm{T}_{3}$. Da mesma maneira, a avaliação dos níveis de Akt fosforilada (Figura 12G) e da razão Akt fosforilada/Akt total (Figura 12I) indicou que o bloqueio do receptor AT1 preveniu totalmente o aumento dos níveis de Akt fosforilada promovido pelo $\mathrm{T}_{3}$.

Após a análise da participação do receptor AT1 para a ativação da Akt induzida pelo $\mathrm{T}_{3}$, avaliamos então a influência exercida por esse receptor na fosforilação/inativação da GSK3- $\beta$ promovida pelo HT. A avaliação dos níveis de GSK3- $\beta$ fosforilada (Ser 9), GSK3- $\beta$ total e razão GSK3- $\beta$ fosforilada/GSK3- $\beta$ total nas culturas primárias de cardiomiócitos controle (Figura 13 A,B,C), nas culturas de cardiomiócitos transfectadas com RNAi para AT1 (Figura 13 D,E,F) e nas culturas pré-tratadas com Losartan, submetidas ao tratamento com $T_{3}$ (Figura 13 G,H,I), são apresentadas a seguir. 

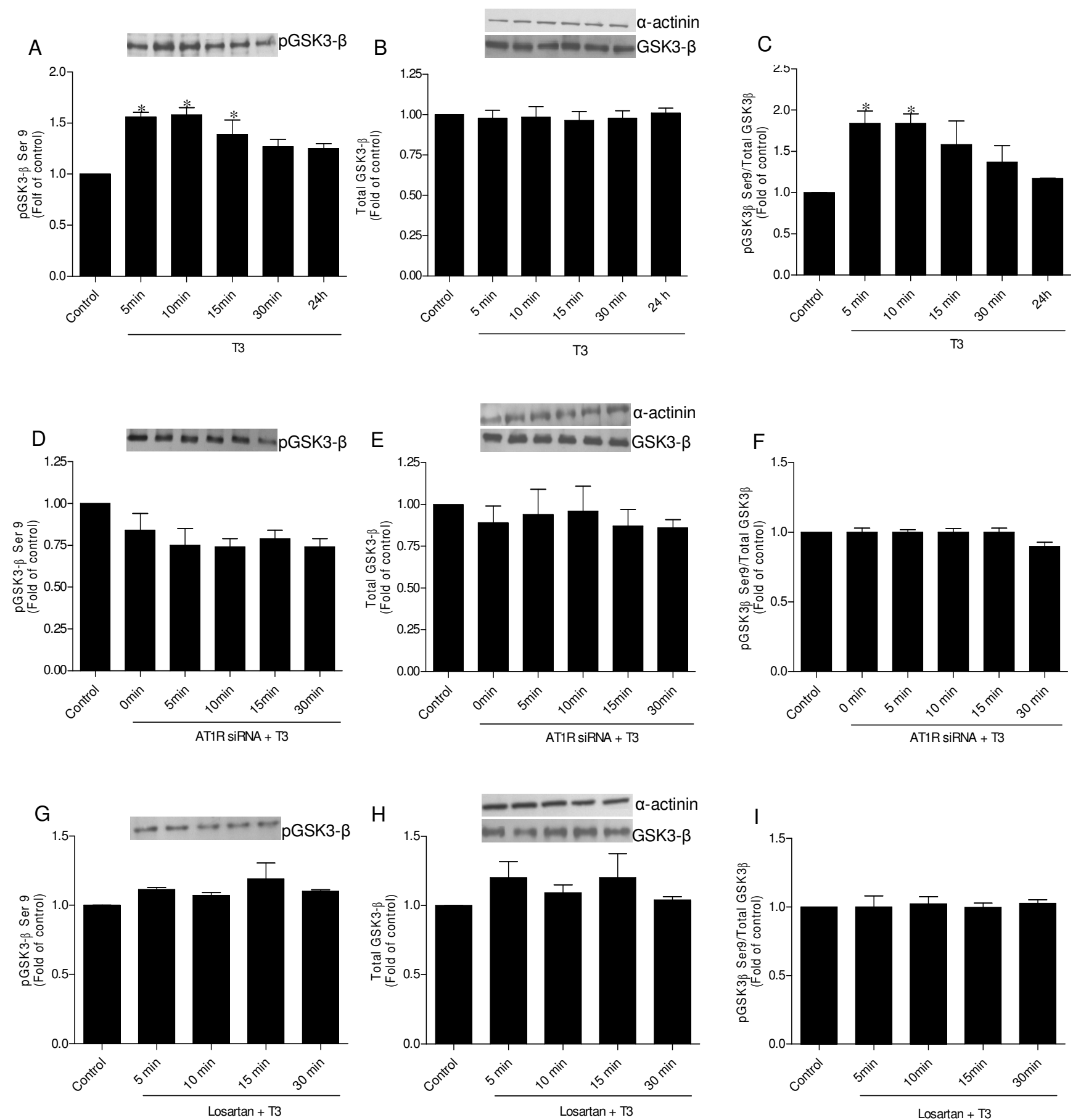

Figura 13- Análise dos níveis de GSK3- $\beta$ fosforilada na $\operatorname{Ser}^{9}$ (A), GSK3- $\beta$ total (B) e razão GSK3- $\beta$ fosforilada na Ser ${ }^{9} /$ GSK3 $^{-} \beta$ total (C) avaliada por Western Blotting, em células tratadas com meio sem soro contendo $10 \eta \mathrm{M}$ de $\mathrm{T}_{3}$ por $5,10,15$, 30 min e 24 horas ou meio sem soro nas células controle. Análise dos níveis de GSK3- $\beta$ fosforilada na $\operatorname{Ser}^{9}$ (D), GSK3- $\beta$ total (E) e razão GSK3- $\beta$ fosforilada na Ser ${ }^{9} /$ GSK3- $\beta$ total (F) em células transfectadas com $50 \eta M$ de RNAi para AT1 por 72 horas, tratadas com meio sem soro contendo $10 \eta \mathrm{M}$ de $\mathrm{T}_{3}$ por $5,10,15$ e $30 \mathrm{~min}$, ou meio sem soro nas células controle. Análise dos níveis de GSK3- $\beta$ fosforilada na $\operatorname{Ser}^{9}$ (G), GSK3- $\beta$ total (H) e razão GSK3- $\beta$ fosforilada na Ser ${ }^{9}$ GSK3- $\beta$ total (I) em células tratadas com meio sem soro contendo $1 \mu \mathrm{M}$ de Losartan (Los) por 30 minutos, e então tratadas com meio sem soro contendo $10 \eta \mathrm{M}$ de $\mathrm{T}_{3}$ por 5, 10, 15 ou 30 min, ou meio sem soro nas células controle. Expressão da $\alpha$-actinina foi usada para normalização. Os valores são representados como vezes de indução em relação às células controle. $* P<0.05$ vs. controle $(\mathrm{n}=4)$. 
Os níveis de GSK-3 $\beta$ fosforilada (Figura 13A) e a razão GSK-3 $\beta$ fosforilada/GSK-3 $\beta$ total (Figura 13C) aumentaram rapidamente após tratamento com $\mathrm{T}_{3}$. Entretanto, as análises dos níveis de GSK-3 $\beta$ fosforilada (Figura 13D) e da razão GSK-3 $\beta$ fosforilada/GSK-3 $\beta$ total (Figura 13F) demonstraram que o silenciamento do receptor AT1 preveniu o aumento dos níveis de GSK-3 $\beta$ fosforilada (inibida) induzida pelo $T_{3}$. Da mesma maneira, a avaliação dos níveis de GSK-3 $\beta$ fosforilada (Figura 13G) e da razão GSK-3 $\beta$ fosforilada/GSK-3 $\beta$ total (Figura 13I) evidenciou que o bloqueio do receptor AT1 preveniu totalmente o aumento dos níveis de GSK$3 \beta$ fosforilada (inibida) induzido pelo $\mathrm{T}_{3}$.

Posteriormente, avaliamos então a possível participação do receptor AT1 para a ativação da mTOR promovida pelo $\mathrm{T}_{3}$. Os resultados referentes às análises dos níveis de mTOR fosforilada, mTOR total e a razão mTOR fosforilada/mTOR total nas culturas primárias de cardiomiócitos controle (Figura 14 A,B,C), nas transfectadas com RNAi para AT1 (Figura 14 D,E,F) e nas culturas pré-tratadas com Losartan, submetidas ao tratamento com $\mathrm{T}_{3}$ (Figura 14 G,H,I) encontram-se a seguir. 

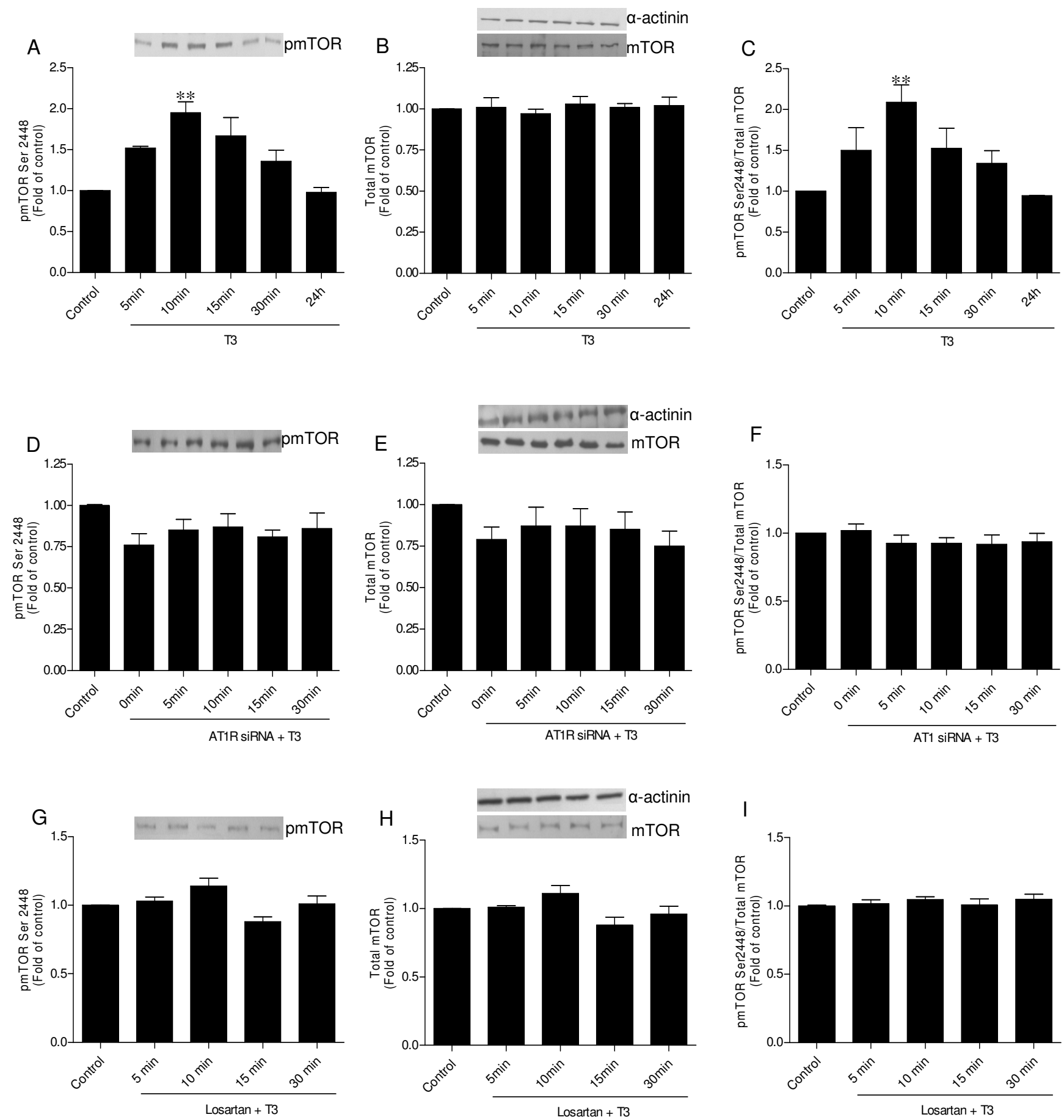

Figura 14- Análise dos níveis de mTOR fosforilada na $\operatorname{Ser}^{2448}$ (A), mTOR total (B) e razão mTOR fosforilada na $\operatorname{Ser}^{2448} / \mathrm{mTOR}$ total (C) avaliada por Western Blotting, em células tratadas com meio sem soro contendo $10 \eta \mathrm{M}$ de $\mathrm{T}_{3}$ por 5 , $10,15,30$ min e 24 horas ou meio sem soro nas células controle. Análise dos níveis de mTOR fosforilada na $\operatorname{Ser}^{2448}$ (D), mTOR total (E) e razão mTOR fosforilada na $\mathrm{Ser}^{2448} / \mathrm{mTOR}$ total (F) em células transfectadas com 50 $\eta \mathrm{M}$ de RNAi para AT1 por 72 horas, tratadas com meio sem soro contendo $10 \eta \mathrm{M}$ de $\mathrm{T}_{3}$ por 5, 10, 15 e $30 \mathrm{~min}$, ou meio sem soro nas células controle. Análise dos níveis de mTOR fosforilada na $\operatorname{Ser}^{2448}(\mathrm{G})$, mTOR total (H) e razão mTOR fosforilada na $\mathrm{Ser}^{2448} / \mathrm{mTOR}$ total (I) em células tratadas com meio sem soro contendo $1 \mu \mathrm{M}$ de Losartan (Los) por 30 min, e então tratadas com meio sem soro contendo $10 \eta \mathrm{M}$ de $\mathrm{T}_{3}$ por 5, 10, 15 ou $30 \mathrm{~min}$, ou meio sem soro nas células controle. Expressão da $\alpha$-actinina foi usada para normalização. Os valores são representados como vezes de indução em relação às células controle. $* * P<0.01$ vs. controle $(\mathrm{n}=4)$. 
Os níveis de mTOR fosforilada (Figura 14A) e a razão mTOR fosforilada/mTOR total (Figura 14C) foram rapidamente aumentados pelo $\mathrm{T}_{3}$. Entretanto, as análises dos níveis de mTOR fosforilada (Figura 14D) e da razão mTOR fosforilada/mTOR total (Figura 14F) demonstraram que as células transfectadas com RNAi para AT1 apresentaram uma prevenção da ativação da mTOR induzida pelo $T_{3}$. Da mesma maneira, a avaliação dos níveis de mTOR fosforilada (Figura 14G) e da razão mTOR fosforilada/mTOR total (Figura 14I) indicou que o bloqueio do receptor AT1 preveniu totalmente o aumento dos níveis de mTOR fosforilada promovido pelo $\mathrm{T}_{3}$.

Os resultados apresentados anteriormente demonstram claramente que o receptor AT1 é fundamental para a ativação da via Akt/GSK3- $\beta / \mathrm{mTOR}$ promovida pelo $\mathrm{T}_{3}$ nas culturas primárias de cardiomiócitos.

\subsection{Avaliação da participação da PI3K para a ativação da via de sinalização Akt/GSK3- $\beta / m$ TOR promovida pelo $T_{3}$}

Com o intuito de avaliar a possível participação da PI3K para a ativação da via da Akt/GSK3- $\beta$ /mTOR promovida pelo $\mathrm{T}_{3}$ utilizamos dois inibidores específicos da PI3K, LY244002 e Wortmannin. A análise dos níveis de Akt fosforilada, Akt total e razão Akt fosforilada/Akt total (Figura 15) nas células tratadas com inibidores da PI3K e T é mostrada a seguir. 

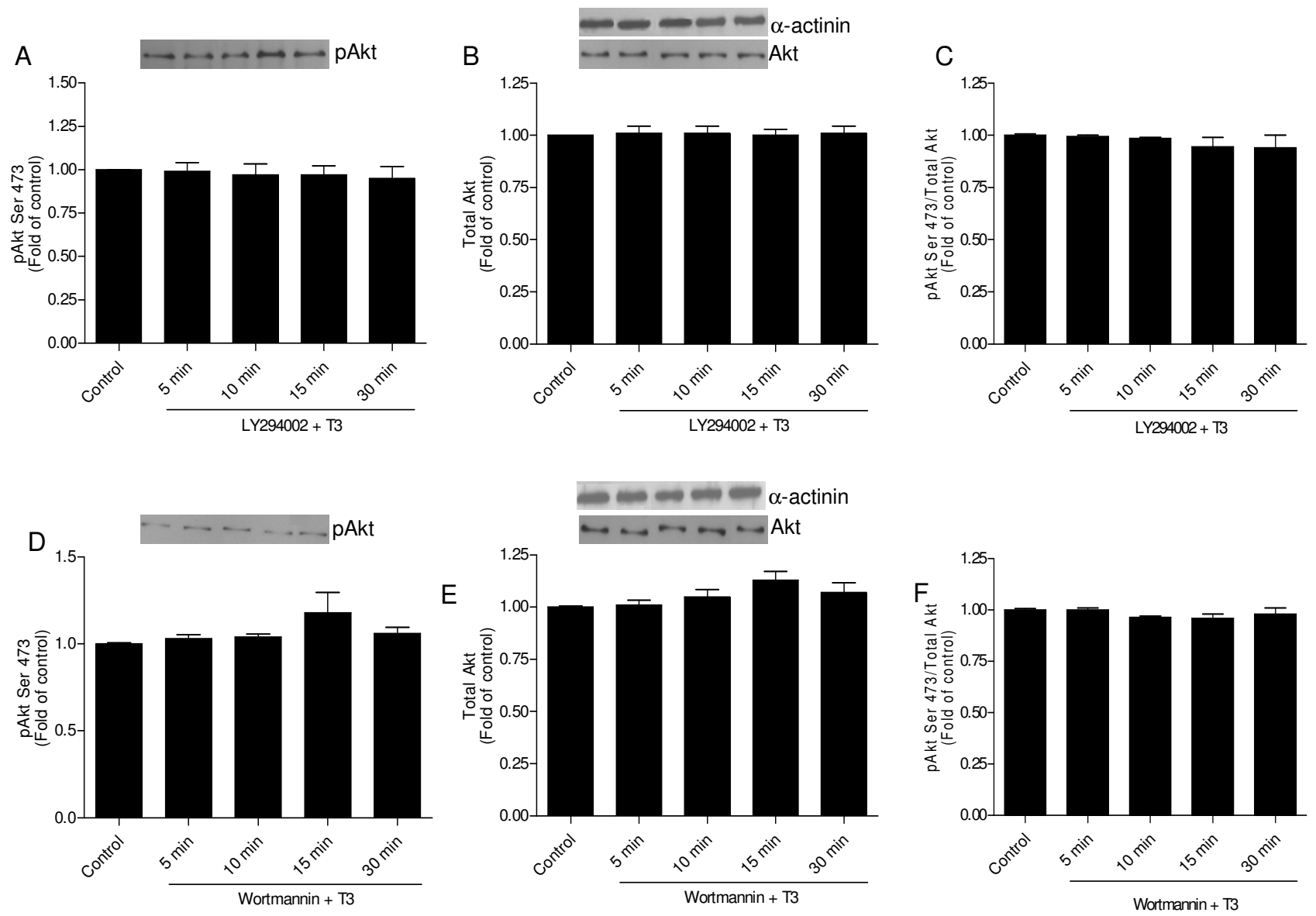

Figura 15- Avaliação dos níveis de Akt fosforilada na $\operatorname{Ser}^{473}$ (A,D), Akt total (B,E) e razão Akt fosforilada na $\mathrm{Ser}^{473} /$ Akt total (C,F), através da técnica de Western Blotting. Os cardiomiócitos foram tratados com meio sem soro nas células controle, ou pré-tratados com meio sem soro contendo $10 \mu \mathrm{M}$ de LY244002 (A,B,C) ou $200 \eta \mathrm{M}$ de Wortmannin (D,E,F) por 30 min. Em seguida as células foram tratadas com o inibidor da PI $3 \mathrm{~K}$ e $\mathrm{T}_{3}(10 \eta \mathrm{M})$ por 5, 10, 15 e $30 \mathrm{~min}(\mathrm{n}=3)$.

A análise dos dados demonstra que a inibição da PI3K preveniu totalmente o aumento dos níveis de Akt fosforilada induzida pelo $\mathrm{T}_{3}$.

Em seguida, avaliamos então o efeito da inibição da PI3K nos níveis de GSK-3 $\beta$ fosforilada, GSK-3 $\beta$ total e na razão GSK-3 $\beta$ fosforilada/GSK-3 $\beta$ total nas culturas primárias de cardiomiócitos tratadas com $\mathrm{T}_{3}$ (Figura 16). Os resultados deste experimento são demonstrados a seguir. 

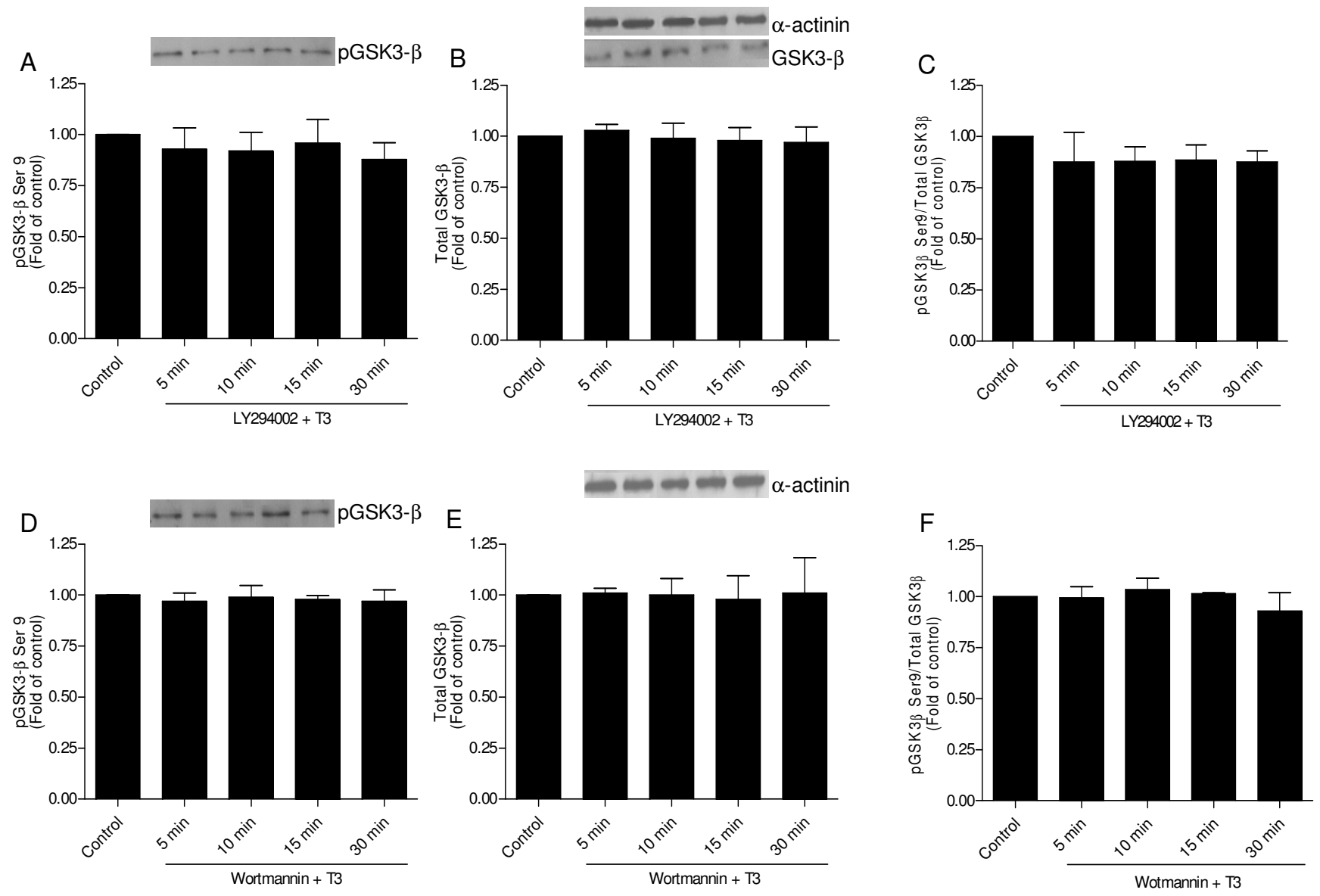

Figura 16- Avaliação dos níveis de GSK3- $\beta$ fosforilada na $\operatorname{Ser}^{9}$ (A,D), GSK3- $\beta$ total (B,E) e razão dos níveis de GSK3- $\beta$ fosforilada na Ser $/$ GSK3- $\beta$ total $(C, F)$, avaliada por Western Blotting. Os cardiomiócitos foram tratados com meio sem soro, nas células controle, ou pré-tratados com meio sem soro contendo $10 \mu \mathrm{M}$ de LY244002 (A,B,C) ou $200 \eta \mathrm{M}$ de Wortmannin (D,E,F) por 30 min. Em seguida as células foram tratadas com o inibidor e $\mathrm{T}_{3}(10 \eta \mathrm{M})$ por $5,10,15$ e $30 \mathrm{~min}(\mathrm{n}=3)$.

De maneira similar ao observado com a Akt, a inibição da PI3K também foi capaz de prevenir completamente o aumento dos níveis de GSK3- $\beta$ fosforilada (inibida) induzida pelo $\mathrm{T}_{3}$.

Posteriormente, avaliamos então o efeito da inibição da PI3K nos níveis de mTOR fosforilada, mTOR total e na razão mTOR fosforilada/mTOR total nas culturas primárias de cardiomiócitos tratadas com $\mathrm{T}_{3}$ (Figura 17). 

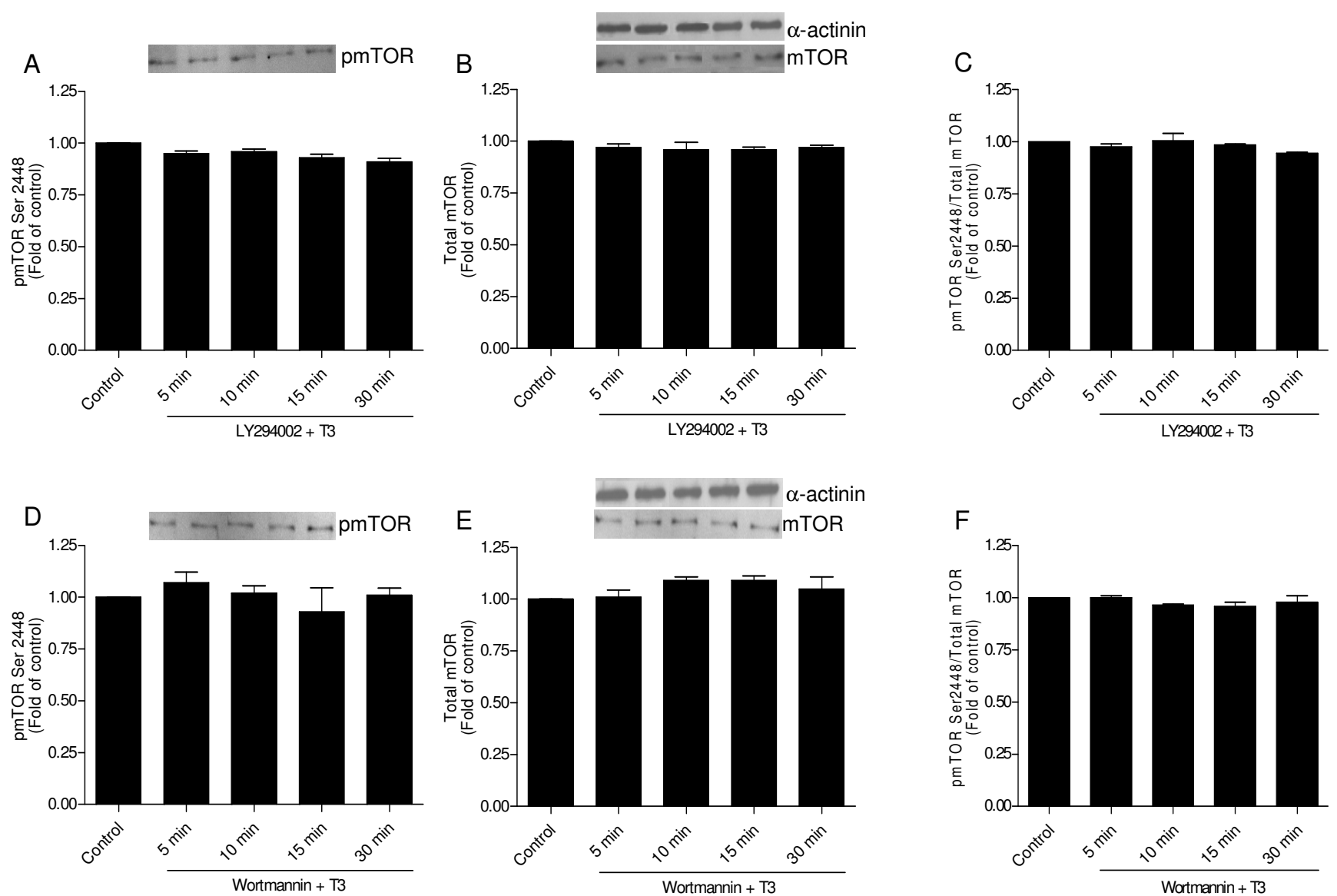

Figura 17- Avaliação dos níveis de mTOR fosforilada na $\operatorname{Ser}^{2448}$ (A,D), mTOR total (B,E) e razão dos níveis de mTOR fosforilada na $\mathrm{Ser}^{2448} / \mathrm{mTOR}$ total (C,F), avaliada por Western Blotting. Os cardiomiócitos foram tratados com meio sem soro, nas células controle, ou pré-tratados com meio sem soro contendo 10 $\mu \mathrm{M}$ de LY244002 (A,B,C) ou $200 \eta \mathrm{M}$ de Wortmannin (D,E,F) por $30 \mathrm{~min}$. Em seguida as células foram tratadas com $\mathrm{T}_{3}(10 \eta \mathrm{M})$ por $5,10,15$ e $30 \mathrm{~min}(\mathrm{n}=3)$.

No mesmo sentido, a utilização dos inibidores de PI3K preveniu totalmente o aumento dos níveis de mTOR fosforilada induzida pelo $\mathrm{T}_{3}$.

Esses resultados mostram que a PI3K participa da ativação da via Akt/GSK3- $\beta / m$ TOR promovida pelo $\mathrm{T}_{3}$. 


\subsection{Análise dos níveis de Ang I/II e da expressão do receptor AT1 em culturas de cardiomiócitos tratadas com $\mathbf{T}_{3}$}

Os resultados apresentados anteriormente evidenciaram que o receptor AT1 é fundamental para o efeito hipertrófico exercido pelo $\mathrm{T}_{3}$, além também de atuar como um mediador da ativação da via da Akt/GSK3- $\beta /$ mTOR induzida pelo $\mathrm{T}_{3}$ nas culturas de cardiomiócitos. Para avaliar se o $\mathrm{T}_{3}$ poderia modular os níveis de Ang I e Ang II no meio de cultura das células, ou ainda influenciar a expressão do receptor AT1, realizou-se então a análise desses componentes nos cardiomiócitos tratados com $\mathrm{T}_{3}$. Os níveis de Ang I e Ang II no meio de cultura foram avaliados por HPLC (Figura 18 A,B), enquanto que a expressão protéica de Ang I/II no lisado celular foi analisada por Western Blot (Figura 18C). A análise da expressão gênica e protéica do receptor AT1 (Figura 19) também foi avaliada.
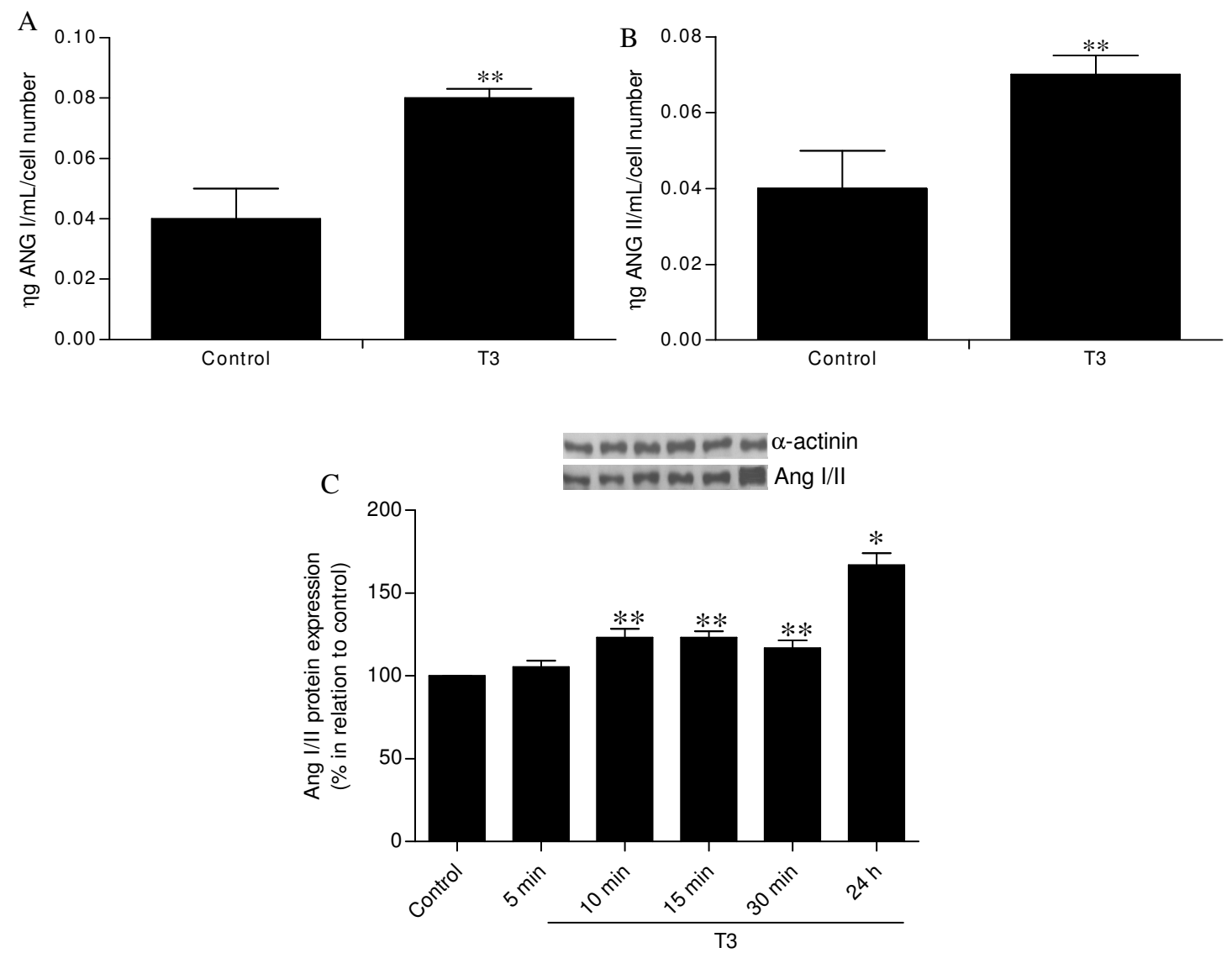

Figura 18- Análise dos níveis de Ang I (A) e Ang II (B) no meio de cultura, avaliados por HPLC. Os cardiomiócitos foram tratados com meio sem soro, nas células controle, ou tratados com meio sem soro contendo $\mathrm{T}_{3}(10 \eta \mathrm{M})$ por 24 horas. Avaliação da expressão protéica de Ang I/II no lisado celular (C) por Western Blotting. Os cardiomiócitos foram tratados com meio sem soro, nas células controle, ou tratados com meio sem soro contendo $\mathrm{T}_{3}(10 \eta \mathrm{M})$ por $5,10,15$ e 30 min ou 24 horas. ${ }^{*} P<0.05$ vs. controle; ${ }^{*} P<0.01$ vs. controle $(\mathrm{n}=3)$. 
As células tratadas com $\mathrm{T}_{3}$ por 24 horas apresentaram um aumento significativo dos níveis de Ang I e Ang II no meio de cultura. No mesmo sentido, as células tratadas com $\mathrm{T}_{3}$ apresentaram um rápido aumento na expressão protéica de Ang I/II no lisado celular, o qual foi mantido pelo menos até 24 horas após o tratamento.

A análise da expressão gênica e protéica do receptor AT1 nas células tratadas com $\mathrm{T}_{3}$, avaliada por RT-PCR em Tempo Real e Western Blot é demonstrada a seguir (Figura 19).

$$
\text { A }
$$

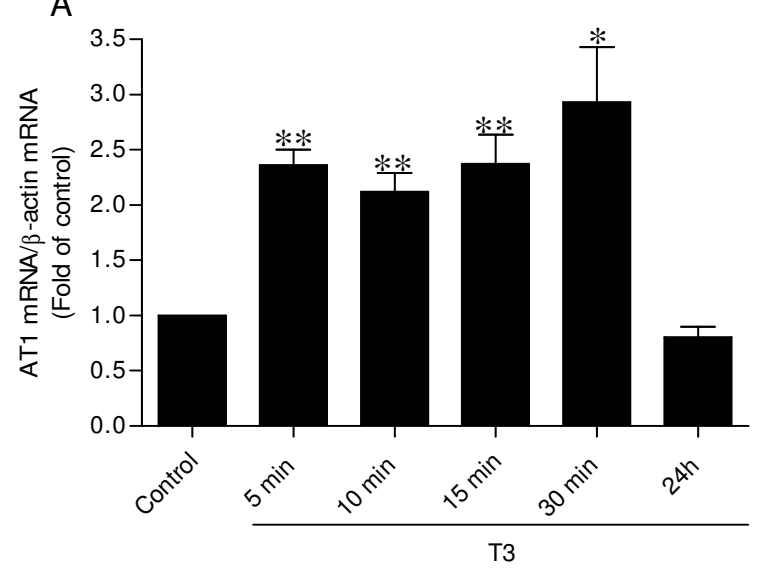

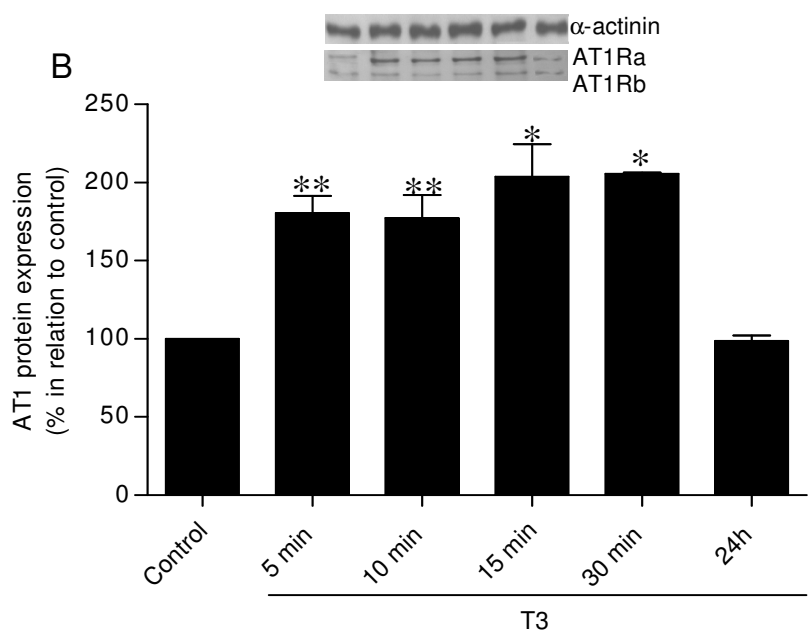

Figura 19- Avaliação da expressão gênica (A) e protéica (B) do receptor AT1 analisada respectivamente por RT-PCR em Tempo Real e Western Blotting. Os cardiomiócitos foram tratados com meio sem soro, nas células controle, ou tratados com meio sem soro contendo $\mathrm{T}_{3}(10 \eta \mathrm{M})$ por 5, 10, 15 e 30 min e 24 horas. $* * P<0.05$ vs. controle; $* P<0.01$ vs. controle (n=3).

Os cardiomiócitos tratados com $\mathrm{T}_{3}$ por $5,10,15$ e 30 min apresentaram um rápido aumento dos níveis de expressão gênica e protéica do receptor AT1. Entretanto, as células tratadas com $\mathrm{T}_{3}$ por 24 horas não apresentaram alteração significativa na expressão do receptor AT1. 


\section{DISCUSSÃO}

O presente estudo teve como objetivos avaliar o possível envolvimento do receptor AT1 para o efeito hipertrófico exercido pelo $T_{3}$ nas culturas de cardiomiócitos, bem como investigar a possível participação deste receptor para a ativação da via da Akt/GSK3- $\beta /$ mTOR induzida pelo $\mathrm{T}_{3}$.

A eficiência, especificidade e baixo custo promovidos pela técnica de RNAi têm atualmente possibilitado a descoberta e compreensão das funções de inúmeros genes em processos fisiológicos e patológicos. Entretanto, a utilização de RNAi para o silenciamento de um gene específico em células de mamíferos requer um selecionamento adequado da sequência a ser empregada, a qual deve ser complementar ao RNAm produzido pela célula. O sucesso de experimentos de RNAi depende, em grande parte, da eficiência de agentes de transfecção, os quais são influenciados ainda pelo tipo e confluência das células em cultura, bem como da estabilidade da proteína que se deseja silenciar. É importante salientar que os agentes mais comuns utilizados para a transfecção das culturas de células, como agentes lipofílicos, eletroporação, plasmídeos e adenovírus, influenciam diretamente o número de células transfectadas (MCMANUS e SHARP, 2002).

Há duas vantagens principais no método de transfecção de RNAi, quando comparado ao silenciamento gênico induzido por plasmídeos. A primeira vantagem é que a transfecção de RNAi é mais eficiente do que a transfecção de plasmídeos. Além disso, a maioria das células transfectadas com RNAi apresentam silenciamento gênico. Ainda, o início do silenciamento gênico nas células transfectadas com RNAi é imediato (DYKXHOORN et al., 2003).

Alguns trabalhos relatam que a eficiência de transfecção de RNAi em culturas primárias restringe-se a apenas alguns tipos celulares (OVCHARENKO et al., 2005). No entanto, nossos resultados demonstraram que o agente lipofílico utilizado como mediador da transfecção foi capaz de transfectar as culturas de cardiomiócitos de maneira eficiente e sem efeito citotóxico aparente, devido à preservação da morfologia e da capacidade contrátil destas células após a transfecção, o que possibilitou a utilização desta técnica como uma ferramenta para avaliar a participação do receptor AT1 tanto para o desenvolvimento da hipertrofia dos cardiomiócitos promovida pelo $\mathrm{T}_{3}$, como também para a ativação da via da Akt nessas células. Os resultados obtidos da transfecção das células com RNAi para AT1 demonstraram ainda que, dependendo do 
conteúdo de G/C da sequência utilizada, o processo de silenciamento ocorre de maneira diferente. Nesse sentido, as células transfectadas com a sequência de RNAi para AT1 com alto conteúdo de G/C apresentaram uma diminuição mais acentuada na expressão gênica e protéica do receptor AT1. Isto provavelmente deve-se ao fato de que a ligação entre $\mathrm{G}$ e $\mathrm{C}$ é proporcionada por três pontes de $\mathrm{H}^{+}$, o que poderia estar influenciando a estabilidade da ligação entre o RNAi e o RNAm da célula, e consequentemente, promovendo uma redução mais acentuada e mais prolongada da expressão do receptor AT1 nos cardiomiócitos.

Além disso, os resultados apresentados neste estudo demonstraram que, apesar da diminuição dos níveis de RNAm do receptor AT1 ter sido observada após 24 horas da transfecção, a redução dos níveis protéicos do receptor AT1 foi atingida somente após 56 horas, a qual se manteve pelo menos até 80 horas após a transfecção. Geralmente, o RNAi induz uma rápida redução dos níveis de RNAm, a qual é observada aproximadamente 18 horas após a transfecção (MCMANUS e SHARP, 2002; AGRAWAL et al., 2003). No entanto, inúmeras proteínas apresentam diferentes "turnovers". Sendo assim, proteínas mais estáveis requerem um período maior de exposição ao RNAi para serem efetivamente silenciadas (MCMANUS e SHARP, 2002). Nossos resultados confirmam, mais uma vez, que o RNAi exerce seu efeito inicialmente nos níveis de RNAm produzidos pela célula, sendo que a diminuição da proteína é observada mais tardiamente devido à maior estabilidade dessa estrutura. Ainda, a utilização do RNAi controle negativo (scramble RNAi) permitiu evidenciar que a diminuição nos níveis do receptor AT1 promovido pelo RNAi foi específico, dependente da sequência empregada para o silenciamento, e independente do processo de transfecção das células. Além disso, nossos resultados mostraram que a expressão do receptor AT2 não foi alterada nas células transfectadas com RNAi para AT1. Este corresponde a um importante resultado no momento de padronização da técnica, uma vez que, ao silenciar um transcrito que codifica um receptor, não é incomum que outros sejam superexpressos, no sentido de compensar o silenciamento do primeiro, podendo algumas vezes levar a falsas interpretações dos resultados experimentais.

\section{SRA e Hormônios tiroideanos}

Sabe-se que os HT induzem à hipertrofia dos cardiomiócitos in vivo e in vitro (KUZMAN et al., 2005; KENESSEY e OJAMAA, 2006). Mais recentemente, a participação do receptor AT1 
no processo de hipertrofia cardíaca induzida por HT in vivo foi evidenciada (HU et al., 2003; PANTOS et al., 2005). Essa descoberta ganhou destaque, uma vez que o receptor AT1 atua como mediador do efeito hipertrófico exercido pela Ang II no desenvolvimento da hipertrofia cardíaca (SADOSHIMA e IZUMO, 1993), além também de mediar os efeitos cronotrópicos e ionotrópicos positivos promovidos pela Ang II no coração (ZHU et al., 2003; MEHTA e GRIENDLING, 2007). Os efeitos hipertróficos da Ang II nas células cardíacas, através da estimulação do receptor AT1, envolvem a ativação sequencial e paralela de uma variedade de proteínas quinases de diferentes vias de sinalização (ORO et al., 2007). Dentre essas diversas vias destaca-se a ativação da via de sinalização dependente de PI3K, a qual tem sido implicada em mediar o crescimento cardíaco (ROCIC et al., 2001; THOMAS et al., 2002). Considerando que os HT modulam diversos parâmetros hemodinâmicos, os quais poderiam ser os responsáveis pela ativação do SRA observada no hipertiroidismo, tornou-se então necessário avaliar se a participação do receptor AT1 na hipertrofia cardíaca induzida por HT era indireta, decorrente de alterações hemodinâmicas, ou direta, decorrente de efeito hipertrófico aditivo da ligação da Ang II ao seu receptor AT1. Os resultados de análise da expressão gênica de ANF e $\alpha$-actina esquelética, associados à análise de síntese protéica mostraram que o silenciamento do receptor AT1 por RNAi, ou o bloqueio farmacológico deste receptor, preveniram totalmente o desenvolvimento da hipertrofia do cardiomiócito promovido pelo $\mathrm{T}_{3}$, demonstrando, portanto, que o receptor AT1 é um mediador crítico do efeito hipertrófico exercido pelo HT nas culturas de cardiomiócitos. Esses resultados sugerem a hipótese de que a contribuição do SRA para o desenvolvimento da hipertrofia cardíaca observada no hipertiroidismo in vivo deve ocorrer principalmente através dos efeitos tróficos, locais, exercido pela ativação do SRA tecidual/celular, e provavelmente independente, ou menos dependente, de alterações hemodinâmicas decorrentes do aumento dos níveis de HT.

\section{Participação do receptor AT1 para a ativação da via da Akt/GSK3- $\beta$ /mTOR}

Por muito tempo o efeito hipertrófico do HT no tecido cardíaco foi atribuído basicamente à alteração da trancrição gênica (KLEIN e OJAMAA, 2001; DILLMANN, 2002). No entanto, há alguns anos surgiram evidências de que os HT também exercem efeitos rápidos nos cardiomiócitos, através da modulação do estado de fosforilação de diversas proteínas de 
sinalização intracelular. Neste sentido, a ativação da via de sinalização da PI3K/Akt/mTOR tem sido implicada como mediadora do efeito hipertrófico exercido pelo HT no tecido cardíaco in vivo e in vitro. Um recente estudo demonstrou que a hipertrofia cardíaca induzida pelo HT in vivo foi acompanhada por elevados níveis de Akt e mTOR fosforilados, no coração (KUZMAN et al., 2005). No entanto, os dados apresentados neste estudo não permitem concluir se o efeito do HT na via de sinalização da Akt foi promovido por um efeito direto deste hormônio, por um efeito indireto, através de alterações de parâmetros hemodinâmicos, ou ainda por uma combinação de ambos. Dessa forma, nos últimos anos, alguns estudos estão analisando os efeitos rápidos exercidos pelo $T_{3}$ na modulação desta via de sinalização em culturas de cardiomiócitos. Nesse sentido, um recente estudo demonstrou que o $\mathrm{T}_{3}$ induz um rápido aumento da atividade da PI3K, resultando em aumentados níveis de Akt e mTOR fosforilados em culturas de cardiomiócitos, os quais foram mediados pela interação entre o receptor de HT (TR $\alpha 1)$ citosólico e a subunidade p85 $\alpha$ da PI3K (KENESSEY e OJAMAA, 2006). Além disso, a participação da PI3K (KENESSEY e OJAMAA, 2006) e da mTOR (KUZMAN et al., 2007) para a hipertrofia dos cardiomiócitos induzida pelo $\mathrm{T}_{3}$ já foi evidenciada, implicando a participação destas quinases, e das proteínas controladas por elas, no efeito hipertrófico exercido pelo $\mathrm{T}_{3}$ nas culturas de cardiomiócitos.

Os dados obtidos neste estudo demonstraram ainda que o $\mathrm{T}_{3}$ é capaz de induzir um rápido aumento nos níveis de Akt fosforilada. Considerando que um dos principais efeitos promovidos pela ativação da Akt nos cardiomiócitos é o aumento da área celular (LATRONICO et al., 2004), é possível que a ativação desta quinase esteja contribuindo para mediar alguns dos efeitos hipertróficos exercidos pelo HT nos cardiomiócitos. Nossos resultados evidenciaram ainda que o silenciamento do receptor AT1 por RNAi, ou a utilização de um bloqueador farmacológico deste receptor, preveniram, ou atenuaram, o aumento dos níveis de Akt fosforilada induzido pelo $\mathrm{T}_{3}$ nas culturas de cardiomiócitos. Considerando que a Akt atua como um mediador da hipertrofia do cardiomiócito, é possível que a prevenção ou a atenuação da ativação desta quinase pelo silenciamento, ou bloqueio do receptor AT1, possa estar contribuindo parcialmente para a ausência de hipertrofia nessas células tratadas com $\mathrm{T}_{3}$.

Duas proteínas controladas pela Akt, implicadas como mediadoras dos efeitos tróficos da ativação desta via em cardiomiócitos são a GSK-3ß e a mTOR. A ativação da Akt promove a fosforilação e inibição da GSK-3ß, a qual é uma proteína inibitória do crescimento celular. 
Normalmente, a GSK-3 $\beta$ inibe a hipertrofia cardíaca principalmente através da fosforilação da proteína $\mathrm{eIF} 2 \mathrm{~B} \varepsilon$, prevenindo o início da síntese protéica. Entretanto, a inibição da GSK-3 $\beta$, através de sua fosforilação, resulta na indução da síntese de proteínas e transcrição gênica, culminando com a hipertrofia (HAQ et al., 2000; ANTOS et al., 2002). Além disso, a inibição de GSK-3 $\beta$ demonstrou ser capaz de induzir a hipertrofia dos cardiomiócitos in vivo e in vitro (MATSUI e ROSENZWEIG, 2005). Os resultados apresentados neste estudo mostraram pela primeira vez que o $\mathrm{T}_{3}$ induz um rápido aumento nos níveis de GSK3- $\beta$ fosforilada nas culturas de cardiomiócitos. Considerando que a fosforilação do resíduo de serina 9 da GSK-3 $\beta$ resulta em sua inibição e, consequentemente, na indução da hipertrofia (DOBLE e WOODGETT, 2003), é possível que os aumentados níveis de GSK-3 $\beta$ fosforilada possam também estar contribuindo em parte para o efeito hipertrófico exercido pelo $\mathrm{T}_{3}$ nas culturas de cardiomiócitos. Entretanto, o silenciamento do receptor AT1 por RNAi, ou o bloqueio farmacológico deste receptor, preveniram totalmente o aumento dos níveis de GSK-3 $\beta$ fosforilada/inibida nas culturas de cardiomiócitos promovido $\mathrm{T}_{3}$, o que também poderia estar contribuindo parcialmente para a ausência de hipertrofia nas células tratadas com $\mathrm{T}_{3}$.

Além disso, os dados apresentados neste estudo evidenciaram também que o $T_{3}$ induz um rápido aumento nos níveis de mTOR fosforilada nas culturas de cardiomiócitos. A mTOR é capaz de fosforilar e ativar diversas proteínas quinases como p70S6K e S6Kinase2, sendo assim considerada um componente chave no controle do crescimento celular através da estimulação da tradução protéica e do aumento da expressão de genes relacionados ao crescimento (SHIMA et al., 1998; DUFNER e THOMAS, 1999; SCHMELZLE e HALL, 2000; LATRONICO et al., 2004; OUDIT et al., 2004). Nossos resultados demonstraram ainda que o receptor AT1 é um importante mediador da ativação da mTOR promovida pelo $\mathrm{T}_{3}$, uma vez que o silenciamento do receptor AT1 por RNAi, ou a utilização de um bloqueador farmacológico, preveniram totalmente o aumento dos níveis de mTOR fosforilada induzido pelo $\mathrm{T}_{3}$, o que também poderia estar contribuindo parcialmente para a ausência de hipertrofia nessas células tratadas com $T_{3}$.

\section{Participação da PI3K para a ativação da via da Akt/GSK3- $\beta / m$ TOR}

Sabendo-se que a PI3K é capaz de interagir com receptores acoplados à proteína G e também mediar a ativação da Akt (SUGDEN et al., 2008), avaliamos então a participação desta 
quinase para a ativação da via da Akt/GSK3- $\beta /$ mTOR induzida pelo $T_{3}$. Os dados apresentados aqui evidenciaram que a PI3K participa da ativação desta via, uma vez que a utilização de inibidores específicos da PI3K impediu o aumento dos níveis de fosforilação da Akt, GSK3- $\beta$ e mTOR induzido pelo $\mathrm{T}_{3}$. É provável que a PI3K, ao interagir com o receptor AT1, esteja mediando a ativação da via da Akt promovida pelo $\mathrm{T}_{3}$. Entretanto, estudos futuros são necessários para avaliar esta hipótese.

\section{Modulação dos níveis de Ang I, Ang II e da expressão do receptor AT1 induzida pelo T $_{3}$}

Levando-se em conta que o receptor AT1 é crítico para o desenvolvimento da hipertrofia dos cardiomiócitos promovido pelo HT, além também de atuar como um mediador da ativação da via da Akt/GSK3- $\beta /$ mTOR, tornou-se fundamental avaliar se o HT poderia modular os níveis de Ang I e Ang II, ou ainda modular a expressão do receptor AT1 nessas células. Nesse contexto, os cardiomiócitos tratados com $\mathrm{T}_{3}$ por 24 horas apresentaram um aumento dos níveis de Ang I e Ang II no meio de cultura. Os possíveis mecanismos implicados nesse processo ainda não são claros. Sabendo-se que a organização do citoesqueleto induzida pelo $\mathrm{T}_{3}$ está envolvida na síntese e secreção de diversos hormônios (GOULART DA SILVA et al., 2006), é possível que o $\mathrm{T}_{3}$ tenha influenciado a secreção desses peptídeos pelos cardiomiócitos. Além disso, considerando que os níveis de Ang I estão aumentados no meio de cultura dos cardiomiócitos tratados com $\mathrm{T}_{3}$, é possível que a ECA, ou outras enzimas, atuem na hidrólise de Ang I em Ang II, o que também poderia contribuir para os elevados níveis de Ang II observados no meio de cultura dessas células. Ainda, é importante considerar que os aumentados níveis de Ang II no meio de cultura dos cardiomiócitos poderia ocorrer como resultante de uma redução da atividade da ECA2, a qual cliva Ang II em Angiotensina 1-7. Nesse sentido, a análise da atividade da ECA e da ECA2 nessas células irá auxiliar na elucidação dos mecanismos exatos implicados nos elevados níveis de Ang II observados no meio de cultura das células tratadas com $\mathrm{T}_{3}$.

Nossos resultados evidenciaram também que as culturas de cardiomiócitos tratadas com $\mathrm{T}_{3}$ apresentaram um rápido aumento dos níveis de Ang I/II no lisado celular e da expressão gênica e protéica do receptor AT1. Considerando que esse aumento foi acompanhado paralelamente por um aumento dos níveis de Akt, GSK3- $\beta$ e mTOR fosforilados é possível que a Ang II, via receptor AT1, seja a responsável por mediar a ativação dessa via de sinalização 
induzida pelo $\mathrm{T}_{3}$. Essa hipótese é plausível uma vez que o silenciamento do receptor AT1 por RNAi, ou o bloqueio farmacológico deste receptor, preveniram o aumento dos níveis de Akt, GSK3- $\beta$ e mTOR fosforilados induzido pelo $T_{3}$. Entretanto, o exato mecanismo pelo qual o receptor AT1 atua como um mediador do efeito hipertrófico exercido pelo $\mathrm{T}_{3}$ necessita ser investigado. Ainda, é importante ressaltar que até o presente momento não existem dados na literatura demonstrando a existência de uma possível interação entre o HT e o receptor AT1, ou ainda entre os RHT e o receptor AT1.

Considerando que os dados apresentados neste estudo evidenciaram que o HT aumenta rapidamente a expressão gênica e protéica do receptor AT1 em cardiomiócitos, e que o HT também induz efeitos pós-transcricionais na estabilidade de vários transcritos (PODDAR et al., 1996; STATON e LEEDMAN, 1998; KAMEGAI, 2001; LI e WAXMAN, 2002; MINAMISAWA, 2006), experimentos avaliando se este hormônio é capaz de modular rapidamente a estabilidade do RNAm do receptor AT1 estão sendo realizados no laboratório, dando sequência ao presente trabalho. Neste sentido, um dos mecanismos pós-transcricionais que influenciam a estabilidade do RNAm é o aumento no comprimento da cauda poli-A, o que o protege da ação de RNases. Os resultados obtidos até o momento mostraram que o $\mathrm{T}_{3}$ promoveu um rápido aumento no comprimento da cauda poli-A do RNAm do receptor AT1 nas culturas de cardiomiócitos, demonstrando, portanto, que o HT aumenta rapidamente a estabilidade do RNAm deste receptor. Este aumento da estabilidade do transcrito do receptor AT1 poderia estar contribuindo, em parte, para o rápido aumento da expressão gênica e protéica do receptor AT1 promovido pelo HT nessas células.

\section{Limitações do estudo}

Sabe-se que o receptor AT1 pode se associar a outros receptores, formando heterodímeros funcionais com o receptor de bradicinina $\mathrm{B} 2$, receptor $\beta$ adrenérgico, receptor Mas e receptor AT2 (ABDALLA et al., 2000; ABDALLA et al., 2001; BARKI-HARRINGTON et al., 2003; KOSTENIS et al., 2005). Além disso, o receptor AT1 pode se associar a receptores tirosina quinase, como o receptor para fator de crescimento epidermal ou receptor para fator de crescimento derivado de plaqueta, o que resulta na ativação de vias de sinalização relacionadas ao crescimento, como ERK e PI3K (TOUYZ e BERRY, 2002; FISCHER et al., 2003), as quais 
também podem contribuir para os efeitos hipertróficos da Ang II no tecido cardíaco (SHAH e CATT, 2004; SMITH et al., 2004). Além disso, é importante enfatizar que o HT pode estimular a produção e liberação de outros fatores de crescimento ou peptídeos, que podem estar atuando de maneira parácrina, ligando-se a receptores na membrana das células e, consequentemente, ativando diversas vias de sinalização intracelular (KUZMAN et al., 2007). Nesse contexto, torna-se evidente que a modulação das vias de sinalização deflagradas pela ativação do receptor AT1 é extremamente ampla e complexa, e, provavelmente, influenciada por outros receptores, os quais podem também estar contribuindo para os dados obtidos neste estudo. Essas hipóteses, no entanto, deverão ser investigadas.

Com base nos resultados obtidos neste estudo, criamos um modelo que sugere os possíveis mecanismos pelos quais o receptor AT1 está envolvido na indução da hipertrofia dos cardiomiócitos promovida pelo $T_{3}$, bem como na ativação da via da Akt/GSK3- $\beta / \mathrm{mTOR}$ observada nesse processo (Figura 20). 


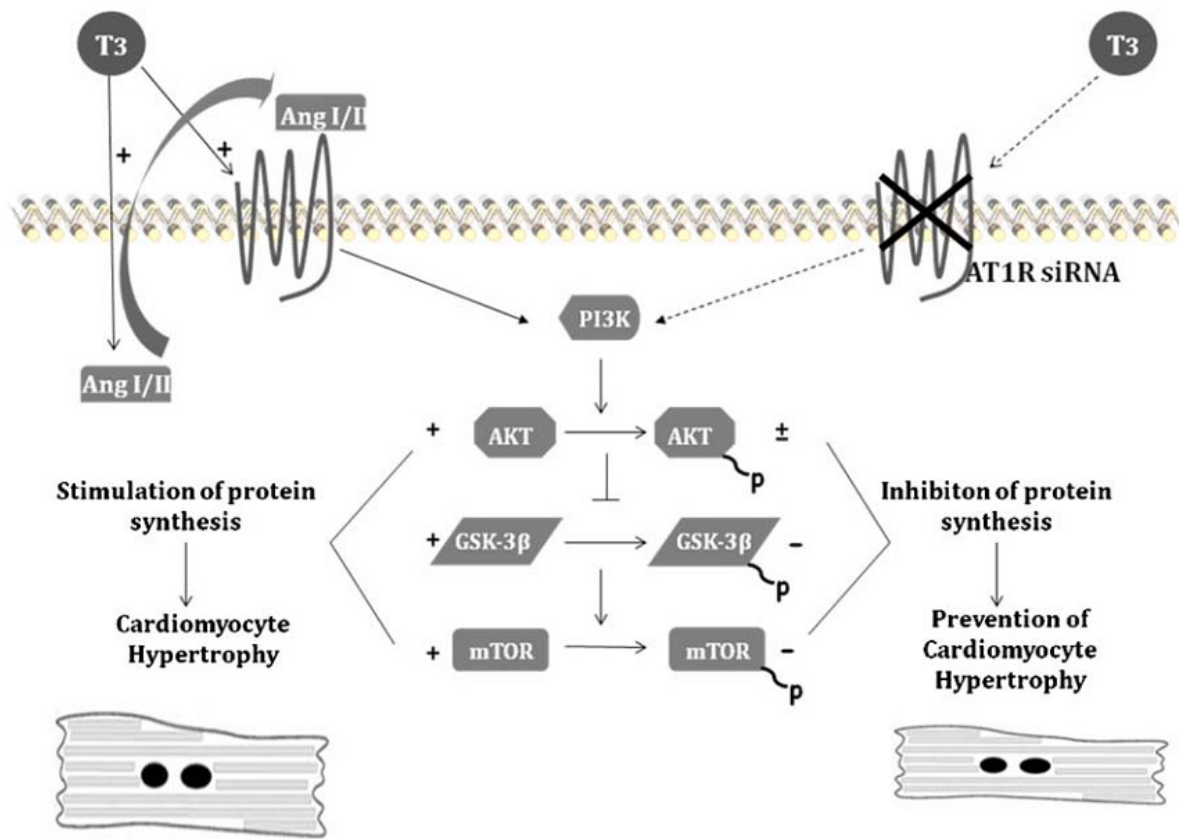

Figura 20- Modelo proposto para a participação do receptor AT1 na hipertrofia dos cardiomiócitos induzida pelo $T_{3}$, bem como na ativação da via da Akt/GSK3- $\beta / m$ TOR. O $T_{3}$ aumenta a expressão da Ang I/II e do receptor AT1 em cardiomiócitos. O receptor AT1 atua como um mediador da ativação da via da Akt/GSK3- $\beta / \mathrm{mTOR}$ promovida pelo $\mathrm{T}_{3}$, resultando na hipertrofia dos cardiomiócitos (lado esquerdo do modelo). Entretanto, o silenciamento do receptor AT1 com RNAi, ou o bloqueio farmacológico deste receptor, atenua ou previne a ativação da via da Akt/GSK3- $\beta / m$ TOR promovida pelo $\mathrm{T}_{3}$, resultando na prevenção da hipertrofia dos cardiomiócitos (lado direito do modelo). O sinal (+) indica ativação, o sinal ( \pm ) indica atenuação, enquanto que o sinal (-) indica inativação. A seta contínua indica ativação induzida pelo $\mathrm{T}_{3}$. A seta descontínua indica prevenção da ativação induzida pelo $\mathrm{T}_{3}$. 


\section{CONCLUSÕES}

Com base nos resultados obtidos junto às culturas primárias de cardiomiócitos do presente estudo podemos concluir que:

- O HT aumenta rapidamente os níveis de Ang I/II sintetizados pela célula e liberados no meio de cultura.

- O HT aumenta rapidamente a expressão gênica e protéica do receptor AT1.

- O efeito hipertrófico promovido pelo HT depende da presença/ativação do receptor AT1 nessas células.

- O receptor AT1 é fundamental para o rápido aumento dos níveis de Akt, GSK3- $\beta$ e mTOR fosforilados induzidos pelo HT, sendo a proteína PI3K a responsável por mediar a ativação dessa via de sinalização.

Diante do exposto anteriormente, esses dados em conjunto sugerem a existência de um novo mecanismo pelo qual o HT induz à hipertrofia dos cardiomiócitos, sugerindo que a via Ang II/receptor AT1/Akt/GSK-3ß/mTOR corresponde a um potencial mediador dos efeitos tróficos exercidos pelo $\mathrm{T}_{3}$ nas culturas de cardiomiócitos. 


\section{REFERÊNCIAS BIBLIOGRÁFICAS}

ABDALLA, S. et al. The angiotensin II AT2 receptor is an AT1 receptor antagonist. J. Biol. Chem., v.276, n.43, p.39721-6, 2001.

ABDALLA, S. et al. AT1-receptor heterodimers show enhanced G-protein activation and altered receptor sequestration. Nature, v.407, n.6800, p.94-8, 2000.

AGRAWAL, N. et al. RNA interference: biology, mechanism, and applications. Microbiol. Mol. Biol. Rev., v.67, n.4, p.657-85, 2003.

AKAZAWA, H.; KOMURO, I. Roles of cardiac transcription factors in cardiac hypertrophy. Circ. Res., v.92, n.10, p.1079-88, 2003.

ALESSI, D.R. et al. Characterization of a 3-phosphoinositide-dependent protein kinase which phosphorylates and activates protein kinase Balpha. Curr. Biol., v.7, n.4, p.261-9, 1997.

ALISI, A. et al. Thyroid hormones regulate DNA-synthesis and cell-cycle proteins by activation of PKCalpha and p42/44 MAPK in chick embryo hepatocytes. J. Cell. Physiol., v.201, n.2, p.259-65, 2004.

ALMEIDA, W.S. et al. Escherichia coli lipopolysaccharide inhibits renin activity in human mesangial cells. Kidney Int., v.69, n.6, p.974-80, 2006.

ANTOS, C.L. et al. Activated glycogen synthase-3 beta suppresses cardiac hypertrophy in vivo. Proc. Natl. Acad. Sci. U S A, v.99, n.2, p.907-12, 2002.

APLIN, M. et al. Pharmacologic perspectives of functional selectivity by the angiotensin II type 1 receptor. Trends. Cardiovasc. Med., v.18, n.8, p.305-12, 2008.

BADER, M. Role of the local renin-angiotensin system in cardiac damage: a minireview focussing on transgenic animal models. J. Mol. Cell. Cardiol., v.34, n.11, p.1455-62, 2002.

BAKER, K.M. et al. Evidence of a novel intracrine mechanism in angiotensin II-induced cardiac hypertrophy. Regul. Pept., v.120, n.1-3, p.5-13, 2004.

BARKI-HARRINGTON, L. et al. Dual inhibition of beta-adrenergic and angiotensin II receptors by a single antagonist: a functional role for receptor-receptor interaction in vivo. Circulation, v.108, n.13, p.1611-8, 2003.

BARRETO-CHAVES, M.L. et al. Stimulatory effect of dexamethasone on angiotensinconverting enzyme in neonatal rat cardiac myocytes. Braz. J. Med. Biol. Res., v.33, n.6, p.661-4, 2000 .

BARRETO-CHAVES, M.L. et al. The crosstalk between thyroid hormones and the Renin Angiotensin System. Vasc. Pharmacol., 2009. 
BARRY, S.P. et al. Molecular regulation of cardiac hypertrophy. Int. J. Biochem. Cell. Biol., v.40, n.10, p.2023-39, 2008.

BEDECS, K. et al. Angiotensin II type 2 receptors mediate inhibition of mitogen-activated protein kinase cascade and functional activation of SHP-1 tyrosine phosphatase. Biochem. J., v.325, p.449-54, 1997, Part 2.

BENKIRANE, K. et al. Peroxisome proliferator-activated receptor gamma regulates angiotensin II-stimulated phosphatidylinositol 3-kinase and mitogen-activated protein kinase in blood vessels in vivo. Hypertension, v.47, n.1, p.102-8, 2006.

BERGH, J.J. et al. Integrin alphaVbeta3 contains a cell surface receptor site for thyroid hormone that is linked to activation of mitogen-activated protein kinase and induction of angiogenesis. Endocrinology, v.146, n.7, p.2864-71, 2005.

BRADFORD, M.M. A rapid and sensitive method for the quantitation of microgram quantities of protein utilizing the principle of protein-dye binding. Anal. Biochem., v.72, p.248-54, 1976.

BUSTIN, S.A. Quantification of mRNA using real-time reverse transcription PCR (RT-PCR): trends and problems. J. Mol. Endocrinol., v.29, n.1, p.23-39, 2002.

CANARIS, G.J. et al. The Colorado thyroid disease prevalence study. Arch. Intern. Med., v.160, n.4, p.526-34, 2000.

CARNEIRO-RAMOS, M.S. et al. Thyroid hormone stimulates 5'-ecto-nucleotidase of neonatal rat ventricular myocytes. Mol. Cell. Biochem., v.265, n.1-2, p.195-201, 2004.

CHIEN, K.R. et al. Regulation of cardiac gene expression during myocardial growth and hypertrophy: molecular studies of an adaptive physiologic response. Faseb J., v.5, n.15, p.303746, 1991.

D'AMORE, A. et al. The angiotensin II type 2 receptor causes constitutive growth of cardiomyocytes and does not antagonize angiotensin II type 1 receptor-mediated hypertrophy. Hypertension, v.46, n.6, p.1347-54, 2005.

DANSER, A.H. Local renin-angiotensin systems. Mol. Cell. Biochem., v.157, n.1-2, p.211-6, 1996.

DAVIS, P. J. et al. Thyroxine promotes association of mitogen-activated protein kinase and nuclear thyroid hormone receptor (TR) and causes serine phosphorylation of TR. J. Biol. Chem., v.275, n.48, p.38032-9, 2000.

DAVIS, P.J.; DAVIS, F.B. Nongenomic actions of thyroid hormone on the heart. Thyroid, v.12, n.6, p.459-66, 2002.

DAVIS, P.J. et al. Membrane receptors mediating thyroid hormone action. Trends_Endocrinol. Metab., v.16, n.9, p.429-35, 2005. 
DAVIS, F.B. et al. Acting via a cell surface receptor, thyroid hormone is a growth factor for glioma cells. Cancer Res., v.66, n.14, p.7270-5, 2006.

DAVIS, P.J. et al. Mechanisms of nongenomic actions of thyroid hormone. Front. Neuroendocrinol., v.29, n.2, p.211-8, 2008.

DE GASPARO, M. et al. International union of pharmacology. XXIII. The angiotensin II receptors. Pharmacol. Rev., v.52, n.3, p.415-72, 2000.

DENG, X.F. et al. Autonomous and growth factor-induced hypertrophy in cultured neonatal mouse cardiac myocytes. Comparison with rat. Circ. Res., v.87, n.9, p.781-8, 2000.

DILLMANN, W.H. Cellular action of thyroid hormone on the heart. Thyroid, v.12, n.6, p.447$52,2002$.

DINIZ, G. P. et al. Angiotensin type 1 (AT1) and type 2 (AT2) receptors mediate the increase in TGF-beta1 in thyroid hormone-induced cardiac hypertrophy. Pflugers Arch., v.454, n.1, p.75-81, 2007.

DINIZ, G.P.; CARNEIRO-RAMOS, M.S.; BARRETO-CHAVES, M.L. Angiotensin type 1 receptor mediates thyroid hormone-induced cardiomyocyte hypertrophy through the Akt/GSK3beta/mTOR signaling pathway. Basic. Res. Cardiol., v.104, n.6, p.653-67, 2009.

DOBLE, B.W.; WOODGETT, J.R. GSK-3: tricks of the trade for a multi-tasking kinase. J. Cell. Sci., v.116, n.Pt 7, p.1175-86, 2003.

DORN, G.W. Novel pharmacotherapies to abrogate postinfarction ventricular remodeling. Nat. Rev. Cardiol., v.6, n.4, p.283-91, 2009.

DORN, G.W.; FORCE T. Protein kinase cascades in the regulation of cardiac hypertrophy. J. Clin. Invest., v.115, n.3, p.527-37, 2005.

DUFNER, A.; THOMAS G. Ribosomal S6 kinase signaling and the control of translation. Exp. Cell. Res., v.253, n.1, p.100-9, 1999.

DYKXHOORN, D.M. et al. Killing the messenger: short RNAs that silence gene expression. Nat. Rev. Mol. Cell. Biol., v.4, n.6, p.457-67, 2003.

DZAU, V.J. Significance of the vascular renin-angiotensin pathway. Hypertension, v.8, n.7, p.553-9, 1986.

DZAU, V.J. Cardiac renin-angiotensin system. Molecular and functional aspects. Am. J. Med., v.84, n.3, p.22-7, 1988.

DZAU, V.J. et al. The relevance of tissue angiotensin-converting enzyme: manifestations in mechanistic and endpoint data. Am. J. Cardiol., v.88, n.9, p.1-20, 2001.

FISCHER, O.M. et al. EGFR signal transactivation in cancer cells. Biochem. Soc. Trans., v.31, n. 6, p.1203-8, 2003. 
FRANCO MDO, C. et al. NADPH oxidase and enhanced superoxide generation in intrauterine undernourished rats: involvement of the renin-angiotensin system. Cardiovasc. Res., v.59, n.3, p.767-75, 2003.

FREY, N. et al. Hypertrophy of the heart: a new therapeutic target? Circulation, v.109, n.13, p.1580-9, 2004.

GOULART DA SILVA, F. et al. Thyroid hormone induction of actin polymerization in somatotrophs of hypothyroid rats: potential repercussions in growth hormone synthesis and secretion. Endocrinology, v.147, n.12, p.5777-85, 2006.

GRIENDLING, K.K. et al. Angiotensin receptors and their therapeutic implications. Annu. Rev. Pharmacol. Toxicol., v.36, p.281-306, 1996.

GUERTIN, D.A. et al. Ablation in mice of the mTORC components raptor, rictor, or mLST8 reveals that mTORC2 is required for signaling to Akt-FOXO and PKCalpha, but not S6K1. Dev. Cell., v.11, n.6, p.859-71, 2006.

HAQ, S. et al. Glycogen synthase kinase-3beta is a negative regulator of cardiomyocyte hypertrophy. J. Cell. Biol., v.151, n.1, p.117-30, 2000.

HARDT, S.E.; SADOSHIMA J. Glycogen synthase kinase-3beta: a novel regulator of cardiac hypertrophy and development. Circ. Res., v.90, n.10, p.1055-63, 2002.

HORIUCHI, M. et al. Recent progress in angiotensin II type 2 receptor research in the cardiovascular system. Hypertension, v.33, n.2, p.613-21, 1999.

HU, L. W. et al. Thyroxine-induced cardiac hypertrophy: influence of adrenergic nervous system versus renin-angiotensin system on myocyte remodeling. Am. J. Physiol. Regul. Integr. Comp. Physiol., v.285, n.6, p.R1473-80, 2003.

HUANG, X. C. et al. Mitogen-activated protein kinases in rat brain neuronal cultures are activated by angiotensin II type 1 receptors and inhibited by angiotensin II type 2 receptors. $\mathbf{J}$. Biol. Chem., v.271, n.26, p.15635-41, 1996.

HUNYADY, L.; CATT K.J. Pleiotropic AT1 receptor signaling pathways mediating physiological and pathogenic actions of angiotensin II. Mol. Endocrinol., v.20, n.5, p.953-70, 2006.

ICHIHARA, A. et al. Differential effects of thyroid hormone on renin secretion, content, and mRNA in juxtaglomerular cells. Am. J. Physiol., v.274, n.2, p.E224-31, 1998.

KAMEGAI, J. et al. Thyroid hormones regulate pituitary growth hormone secretagogue receptor gene expression. J. Neuroendocrinol., v.13, n.3, p.275-8, 2001.

KENESSEY, A.; OJAMAA, K. Thyroid hormone stimulates protein synthesis in the cardiomyocyte by activating the Akt-mTOR and p70S6K pathways. J. Biol. Chem., v.281, n.30, p.20666-72, 2006. 
KLEIN, I.; LEVEY, G.S. New perspectives on thyroid hormone, catecholamines, and the heart. Am. J. Med., v.76, n.2, p.167-72, 1984.

KLEIN, I.; OJAMAA, K. Thyroid hormone and the cardiovascular system. N. Engl. J. Med., v.344, n.7, p.501-9, 2001.

KOBORI, H. et al. Thyroid hormone stimulates renin synthesis in rats without involving the sympathetic nervous system. Am. J. Physiol., v.272, n.2 Pt 1, p.E227-32, 1997.

KOBORI, H. et al. Local renin-angiotensin system contributes to hyperthyroidism-induced cardiac hypertrophy. J. Endocrinol., v.160, n.1, p.43-7, 1999.

KOSTENIS, E. et al. G-protein-coupled receptor Mas is a physiological antagonist of the angiotensin II type 1 receptor. Circulation, v.111, n.14, p.1806-13, 2005.

KOZAWA, O. et al. Activation of p44/p42 mitogen-activated protein kinase limits triiodothyronine-stimulated alkaline phosphatase activity in osteoblasts. Biochem. Biophys. Res. Commun., v.286, n.5, p.1140-3, 2001.

KUDOH, S. et al. Angiotensin II stimulates c-Jun NH2-terminal kinase in cultured cardiac myocytes of neonatal rats. Circ. Res., v.80, n.1, p.139-46, 1997.

KUMAR, R. BOIM, M.A. Diversity of pathways for intracellular angiotensin II synthesis. Curr. Opin. Nephrol. Hypertens., v.18, n.1, p.33-9, 2009.

KUZMAN, J.A. et al. L-Thyroxine activates Akt signaling in the heart. J. Mol. Cell. Cardiol., v.39, n.2, p.251-8, 2005.

KUZMAN, J.A. et al. Thyroid hormone activates Akt and prevents serum starvation-induced cell death in neonatal rat cardiomyocytes. J. Mol. Cell. Cardiol., v.39, n.5, p.841-4, 2005.

KUZMAN, J.A. et al. Rapamycin prevents thyroid hormone-induced cardiac hypertrophy. Endocrinology, v.148, n.7, p.3477-84, 2007.

LATRONICO, M.V. et al. Regulation of cell size and contractile function by AKT in cardiomyocytes. Ann. N. Y. Acad. Sci., v.1015, p.250-60, 2004.

LIJNEN, P.; PETROV, V. Renin-angiotensin system, hypertrophy and gene expression in cardiac myocytes. J. Mol. Cell. Cardiol., v.31, n.5, p.949-70, 1999.

LIN, H.Y. et al. Thyroid hormone induces activation of mitogen-activated protein kinase in cultured cells. Am. J. Physiol, v.276, n.5 Pt 1, p.C1014-24, 1999.

LIU, D.; WAXMAN, D.J. Post-transcriptional regulation of hepatic NADPH-cytochrome P450 reductase by thyroid hormone: independent effects on poly(A) tail length and mRNA stability. Mol. Pharmacol., v.61, n.5, p.1089-96, 2002.

LINDPAINTNER, K. et al. Intracardiac generation of angiotensin and its physiologic role. Circulation, v.77, n.6 Pt 2, p.I18-23, 1988. 
LONG, C. S. et al. Sympathetic activity: modulator of myocardial hypertrophy. J. Cardiovasc. Pharmacol., v.17 Suppl 2, p.S20-4, 1991.

LORELL, B.H.; CARABELLO, B.A. Left ventricular hypertrophy: pathogenesis, detection, and prognosis. Circulation, v.102, n.4, p.470-9, 2000.

MATSUI, T. et al. Akt and PI 3-kinase signaling in cardiomyocyte hypertrophy and survival. Cell. Cycle, v.2, n.3, p.220-3, 2003.

MATSUI, T.; ROSENZWEIG, A. Convergent signal transduction pathways controlling cardiomyocyte survival and function: the role of PI 3-kinase and Akt. J. Mol. Cell. Cardiol., v.38, n.1, p.63-71, 2005.

MCMANUS, M. T.; SHARP, P.A. Gene silencing in mammals by small interfering RNAs. Nat. Rev. Genet., v.3, n.10, p.737-47, 2002.

MEHTA, P.K.; GRIENDLING, K.K. Angiotensin II cell signaling: physiological and pathological effects in the cardiovascular system. Am. J. Physiol. Cell. Physiol., v.292, n.1, p.C82-97, 2007.

MINAMISAWA, S. et al. Post-transcriptional downregulation of sarcolipin mRNA by triiodothyronine in the atrial myocardium. FEBS Lett., v.580, n.9, p.2247-52, 2006.

MOLKENTIN, J.D. Calcineurin-NFAT signaling regulates the cardiac hypertrophic response in coordination with the MAPKs. Cardiovasc. Res., v.63, n.3, p.467-75, 2004.

NAGA PRASAD, S.V. et al. Gbetagamma-dependent phosphoinositide 3-kinase activation in hearts with in vivo pressure overload hypertrophy. J. Biol. Chem., v.275, n.7, p.4693-8, 2000.

ORO, C. et al. Type 1 angiotensin receptor pharmacology: signaling beyond G proteins. Pharmacol. Ther., v.113, n.1, p.210-26, 2007.

OUDIT, G.Y. et al. The role of phosphoinositide-3 kinase and PTEN in cardiovascular physiology and disease. J. Mol. Cell. Cardiol., v.37, n.2, p.449-71, 2004.

OVCHARENKO, D. et al. High-throughput RNAi screening in vitro: from cell lines to primary cells. Rna, v.11, n.6, p.985-93, 2005.

PANTOS, C. et al. Thyroid hormone is a critical determinant of myocardial performance in patients with heart failure: potential therapeutic implications. Eur. J. Endocrinol., v.157, n.4, p.515-20, 2007.

PANTOS, C. et al. Blockade of angiotensin II type 1 receptor diminishes cardiac hypertrophy, but does not abolish thyroxin-induced preconditioning. Horm. Metab. Res., v.37, n.8, p.500-4, 2005.

PAUL, M. et al. Physiology of local renin-angiotensin systems. Physiol. Rev., v.86, n.3, p.747803, Jul. 2006. 
PODDAR, R. et al. Regulation of actin and tubulin gene expression by thyroid hormone during rat brain development. Brain Res. Mol. Brain Res., v.35, n.1-2, Jan, p.111-8. 1996.

RE, R.N. Mechanisms of disease: local renin-angiotensin-aldosterone systems and the pathogenesis and treatment of cardiovascular disease. Nat. Clin. Pract. Cardiovasc. Med., v.1, n.1, p.42-7, 2004.

ROCIC, P. et al. A role for PYK2 in regulation of ERK1/2 MAP kinases and PI 3-kinase by ANG II in vascular smooth muscle. Am. J. Physiol. Cell. Physiol., v.280, n.1, p.C90-9. 2001.

RUBANYI, G.M.; POLOKOFF, M.A. Endothelins: molecular biology, biochemistry, pharmacology, physiology, and pathophysiology. Pharmacol. Rev., v.46, n.3, p.325-415, 1994.

SADOSHIMA, J.; IZUMO, S. Molecular characterization of angiotensin II--induced hypertrophy of cardiac myocytes and hyperplasia of cardiac fibroblasts. Critical role of the AT1 receptor subtype. Circ. Res., v.73, n.3, p.413-23, 1993.

SADOSHIMA, J.; IZUMO, S. The cellular and molecular response of cardiac myocytes to mechanical stress. Annu. Rev. Physiol., v.59, p.551-71, 1997.

SANTOS, R.A. et al. Recent advances in the angiotensin-converting enzyme 2-angiotensin(1-7)Mas axis. Exp. Physiol., v.93, n.5, p.519-27, 2008.

SCHAUB, M. C. et al. Various hypertrophic stimuli induce distinct phenotypes in cardiomyocytes. J. Mol. Med., v.75, n.11-12, p.901-20, 1997.

SCHMELZLE, T.; HALL, M.N. TOR, a central controller of cell growth. Cell, v.103, n.2, p.253$62,2000$.

SCHIMIDT-OTT, U.M.; ASCHEIM, D.D. Thyroid hormone and heart failure. Curr. Heart Fail. Rep., v.3, n.3, p.114-9, 2006.

SENBONMATSU, T. et al. Evidence for angiotensin II type 2 receptor-mediated cardiac myocyte enlargement during in vivo pressure overload. J. Clin. Invest., v.106, n.3, p.R25-9, 2000.

SHAH, B.H.; CATT, K.J. Matrix metalloproteinase-dependent EGF receptor activation in hypertension and left ventricular hypertrophy. Trends Endocrinol. Metab., v.15, n.6, p.241-3, 2004.

SHIH, A. et al. Thyroid hormone promotes serine phosphorylation of p53 by mitogen-activated protein kinase. Biochemistry, v.40, n.9, p.2870-8, 2001.

SHIMA, H. et al. Disruption of the p70(s6k)/p85(s6k) gene reveals a small mouse phenotype and a new functional S6 kinase. Embo J., v.17, n.22, p.6649-59, 1998.

SHIOJIMA, I.; WALSH, K. Regulation of cardiac growth and coronary angiogenesis by the Akt/PKB signaling pathway. Genes Dev., v.20, n.24, p.3347-65, 2006. 
SMITH, N.J., et al. Hijacking epidermal growth factor receptors by angiotensin II: new possibilities for understanding and treating cardiac hypertrophy. Cell. Mol. Life Sci., v.61, n.21, p.2695-703, 2004.

STATON, J.M.; LEEDMAN,P.J. Posttranscriptional regulation of thyrotropin beta-subunit messenger ribonucleic acid by thyroid hormone in murine thyrotrope tumor cells: a conserved mechanism across species. Endocrinology, v.139, n.3, p.1093-100, 1998.

SUGDEN, P. H. et al. Glycogen synthase kinase 3 (GSK3) in the heart: a point of integration in hypertrophic signalling and a therapeutic target? A critical analysis. Br. J. Pharmacol., v.153, p.S137-53, 2008.

TAKANO, H. et al. Activation of p70 S6 protein kinase is necessary for angiotensin II-induced hypertrophy in neonatal rat cardiac myocytes. FEBS Lett., v.379, n.3, p.255-9, 1996.

THOMAS, W.G. et al. Adenoviral-directed expression of the type 1A angiotensin receptor promotes cardiomyocyte hypertrophy via transactivation of the epidermal growth factor receptor. Circ. Res., v.90, n.2, p.135-42, 2002.

TOKER, A.; NEWTON, A.C. Cellular signaling: pivoting around PDK-1. Cell, v.103, n.2, p.185-8, 2000.

TOUYZ, R.M.; BERRY, C. Recent advances in angiotensin II signaling. Braz. J. Med. Biol. Res., v.35, n.9, p.1001-15, 2002.

VAN KATS, J.P. et al. Angiotensin production by the heart: a quantitative study in pigs with the use of radiolabeled angiotensin infusions. Circulation, v.98, n.1, p.73-81, 1998.

VAN ROOIJ, E. et al. Control of stress-dependent cardiac growth and gene expression by a microRNA. Science, v.316, n.5824, p.575-9, 2007.

VANHAESEBROECK, B.; ALESSI, D.R. The PI3K-PDK1 connection: more than just a road to PKB. Biochem. J., v.346, p.561-76, 2000.

VOLPE, M. et al. Angiotensin II AT2 receptor subtype: an uprising frontier in cardiovascular disease? J. Hypertens., v.21, n.8, p.1429-43, 2003.

WANG, B. et al. Effects of triiodo-thyronine on angiotensin-induced cardiomyocyte hypertrophy: reversal of increased beta-myosin heavy chain gene expression. Can. J. Physiol. Pharmacol., v.84, n.8-9, p.935-41, 2006.

WEBER, K.T.; BRILLA, C.G. Pathological hypertrophy and cardiac interstitium. Fibrosis and renin-angiotensin-aldosterone system. Circulation, v.83, n.6, p.1849-65, 1991.

WEISSEL, M. Disturbances of thyroid function in the elderly. Wien. Klin. Wochenschr., v.118, n.1-2, p.16-20, 2006. 
WRUTNIAK-CABELLO, C. et al. Thyroid hormone action in mitochondria. J. Mol. Endocrinol., v.26, n.1, p.67-77, 2001.

YUSUF, S. et al. Effects of an angiotensin-converting-enzyme inhibitor, ramipril, on cardiovascular events in high-risk patients. The Heart Outcomes Prevention Evaluation Study Investigators. N. Engl. J. Med., v.342, n.3, p.145-53, 2000.

ZHANG, T.; BROWN, J.H. Role of $\mathrm{Ca} 2+/$ calmodulin-dependent protein kinase II in cardiac hypertrophy and heart failure. Cardiovasc. Res., v.63, n.3, p.476-86, 2004.

ZHU, Y.C. et al. Role of angiotensin AT1 and AT2 receptors in cardiac hypertrophy an remodelling. Clin. Exp. Pharmacol. Physiol., v.30, n.12, p.911-8, 2003. 
ANEXO A 
Review

\title{
The crosstalk between thyroid hormones and the Renin-Angiotensin System
}

\author{
Maria Luiza M. Barreto-Chaves *, Maria Alícia Carrillo-Sepúlveda, Marcela S. Carneiro-Ramos, \\ Dayane A. Gomes, Gabriela P. Diniz
}

Laboratory of Cell Biology and Functional Anatomy, Department of Anatomy, Institute of Biomedical Sciences of University of São Paulo, São Paulo, Brazil

\section{A R T I C L E I N F O}

\section{Article history:}

Received 12 October 2009

Accepted 18 October 2009

Available online $\mathrm{xxxx}$

\section{Keywords:}

Thyroid hormones

Renin-Angiotensin System

Cardiac hypertrophy

Vasodilatation

\begin{abstract}
A B S T R A C T
Thyroid hormones (THs) exert multiple effects on the heart and vascular system. As a consequence, altered cardiovascular function observed in the thyroid diseases corresponds to one of the most important and clinically relevant aspects found in both hyperthyroidism and hypothyroidism. Besides THs' direct effects on the heart and vascular system, in the last three decades several studies have implicated the ReninAngiotensin System (RAS) in some of the cardiovascular effects of THs, with this interaction suggesting that RAS may be an important mediator of THs actions. In the present review, we discuss the alterations in the circulating RAS, as well as modifications in cardiac and vascular RAS which are involved in the cardiovascular alterations found during the modulation of TH levels. In addition, considering the important role that both systems present during fetal and neonatal periods, we also review the interaction between THs and the RAS in the development of cardiovascular system. A greater understanding of the role of the RAS in hyperthyroidism and hypothyroidism, during early or adult life will presumably facilitate the evolution of newer, targeted therapies.
\end{abstract}

(c) 2009 Elsevier Inc. All rights reserved.

\section{Contents}

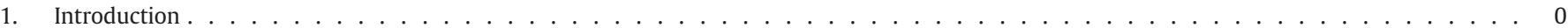

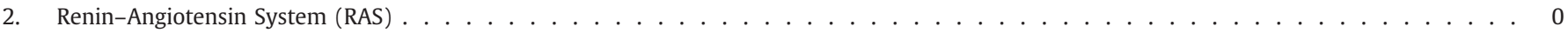

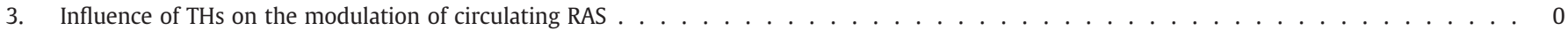

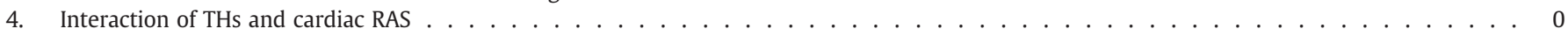

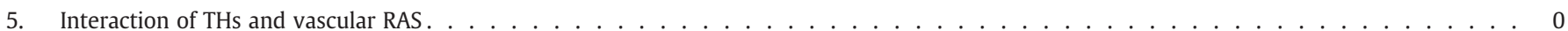

6. Influence of THs on the modulation of RAS in fetal and neonatal periods . . . . . . . . . . . . . . . . . . . . . . . . . . . . . 0

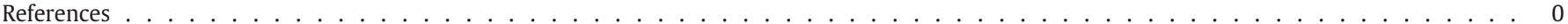

\section{Introduction}

Thyroid hormones (THs) exert broad effects on the cardiovascular system, increasing cardiac contractility and output, inducing arterial relaxation, and reducing systemic vascular resistance. The cellular and molecular mechanisms by which THs exert their actions on the cardiomyocyte and on the systemic vasculature have been demonstrated in the literature. Thus, T3 acts by binding to thyroid hormone (TH) nuclear receptors (TRs), which mediate the induction of transcription by binding to $\mathrm{TH}$ response elements (TREs) in the promoter regions of positively regulated genes (Brent, 1994; Kahaly and Dillmann, 2005). Over the past few years, some studies have shown that THs also exert

\footnotetext{
* Corresponding author. Department of Anatomy, Institute of Biomedical Sciences, University of São Paulo Avenida Professor Lineu Prestes, 2415 05508-900 - São PauloSP-Brazil. Tel.: +55 1130918049 .

E-mail address: mchaves@usp.br (M.L.M. Barreto-Chaves).
}

extranuclear nongenomic effects on the cardiomyocyte and on the vascular smooth muscle cells (VSMCs), which occur rapidly and do not involve TRE-mediated transcriptional events (Davis and Davis, 2002; Hiroi et al., 2006). The rapid effects mediated by T3 include altered actin polymerization, together with changes in various membrane ion channels permeable to sodium, potassium, and calcium, as well as effects on the adenine nucleotide translocator 1 in the mitochondrial membrane and a variety of intracellular signaling pathways in the heart and VSMCs (Goulart da Silva et al., 2006; Klein and Danzi, 2007; Park et al., 1997). In this context, the genomic and nongenomic events promoted by $\mathrm{T} 3$ act in concert to regulate cardiac function and cardiovascular hemodynamics.

Additionally to THs' direct effects on the cardiovascular system, in the last three decades several studies have implicated the ReninAngiotensin System (RAS) in some of the cardiovascular effects of THs, with this interaction suggesting that RAS may be an important mediator of TH actions. Finally, emerging results suggest the possibility 
that disrupted interactions between the two systems may help to explain the variability of cardiovascular manifestations observed in hypo or hyperthyroidism.

\section{Renin-Angiotensin System (RAS)}

For almost a century the RAS was characterized as an important regulator of blood pressure as well as fluid and electrolyte balance. However, in the last two decades, several studies have produced evidence that the RAS plays a critical role in the pathophysiology of cardiovascular diseases (Bomback and Toto, 2009). In the classical concept, the RAS is triggered by the release of renin into the circulation where it converts angiotensinogen to angiotensin I (Ang I), which is hydrolyzed by an ectoenzyme peptidyl dipeptidase, the angiotensin-converting enzyme (ACE), to form angiotensin II (Ang II), which exerts its effects via the Ang II type 1 (AT1) and type 2 receptors (AT2).

The identification in the early 90s of the majority of the RAS components in various tissues and cells not previously considered part of the classical RAS suggested the existence of local RAS (Dzau and Re, 1994; Lavoie and Sigmund, 2003) with organ-specific functions that may act independently from the plasma RAS (Paul et al., 2006). These findings have led to the hypothesis of paracrineautocrine functions for the RAS, which implies that locally generated Ang II mediates effects within a tissue or within a cell (intracrine functions) (Kumar et al., 2007). For example, cells related to the cardiovascular system have been shown to possess all the molecular machinery necessary to generate and secrete Ang II (Danser, 1996) and this local Ang II production process is commonly held to be a "tissue" or "local" RAS. It seems likely then, that whereas the circulating endocrine RAS appears to be responsible for robust effects, the local RAS participates in more 'fine-tuned' processes such as secondary structural changes, and therefore may contribute to the pathogenesis of cardiac hypertrophy as well as other cardiovascular disorders such as coronary artery disease, and atherosclerosis.

In the last few years, in addition to the classical RAS components, several new participants in the system have been discovered such as the ACE2 enzyme, an important Ang (1-7)-forming enzyme (Tipnis et al., 2000; Donoghue et al., 2000), the Mas receptor, an Ang (1-7) receptor (Santos et al., 2003) and other enzymes which also catalyze Ang I to Ang II conversion such as cathepsins and chymase (Cristovam et al., 2008; Lavrentyev et al., 2007). The identification of these components in cells from the cardiovascular system has contributed to transforming our understanding of the RAS from the classical, limitedproteolysis linear cascade to a cascade involving multiple mediators, multiple receptors and multifunctional enzymes (Santos et al., 2008). The physiological role of these new RAS components is not yet completely resolved, but they probably exert a considerable impact on local Ang II generation and effect mediation, which is intensely dependent on the site of synthesis and nature of the stimulus.

\section{Influence of THs on the modulation of circulating RAS}

The RAS has been reported to be significantly upregulated in certain pathologies such as hyperthyroidism. In this condition, there is an increase in the synthesis and secretion of angiotensinogen (Bouhnik et al., 1981; Hong-Brown and Deschepper, 1992) and the plasma renin activity and secretion in rats (Ganong, 1982; Marchant et al., 1993; Montiel et al., 1984; Basset et al., 2001) and in hyperthyroid patients (Zdrojewicz, 1991) when compared to healthy controls. In contrast, the plasma renin activity is reduced in patients with hypothyroidism (Elias et al., 1986; Zdrojewicz and Plamieniak, 1993) as well as in experimental hypothyroidism (Jimenez et al., 1984; Marchant et al., 1993). The cascade of events that follows includes increased levels of Ang I, ACE and Ang II. In fact, it was reported that in hyperthyroid patients the serum ACE activity is increased but no difference was found between the hypothyroid patients and normal subjects (Gotoh et al., 1984). Two decades later, with the advance of new technologies, a tissue-specific modulation of ACE was identified in experimental hyperthyroidism, with the demonstration of increased serum, pulmonary and renal ACE levels, though these were, surprisingly, diminished in the heart (Carneiro-Ramos et al., 2006). Therefore, these data indicate that different mechanisms and local conditions may activate a specific RAS component. Thus, greater understanding of the complexity of the system may help in the design of disease-specific interventions for the blockade of local RAS.

\section{Interaction of THs and cardiac RAS}

Beside important changes in the circulating RAS, THs are responsible for modifications in cardiac RAS which are involved in the cardiovascular alterations found during the modulation of TH levels. Studies have confirmed that THs activate some components of cardiac RAS, with the demonstration that hyperthyroidism promotes an increase in cardiac levels of renin, stimulates Ang II generation (Kobori et al., 1997a, b) and raises the levels of AT1 and AT2 receptors (Sernia et al., 1993; Marchant et al., 1993). In the heart, Ang II exhibits growth-promoting effects by inducing hypertrophy and fibrosis, mediated by the AT1 receptor (Bader and Ganten, 2008). Through this receptor, Ang II activates various intracellular protein kinases implicated in the development of hypertrophy, such as members of the mitogen-activated protein kinase family, the 70-kDa ribosomal protein S6 kinase, several protein kinase $\mathrm{C}$ isoforms, focal adhesion kinase and the Akt signaling pathway (Schluter and Wenzel, 2008).

The contribution of the RAS to cardiac growth found in hyperthyroidism was demonstrated by several studies reported in the literature, which showed that AT1 receptor blockade and ACE inhibition attenuate or prevent the development of cardiac hypertrophy induced by THs in vivo (Asahi et al., 2001; Basset et al., 2001; Hu et al., 2003; Kobori et al., 1997b; Pantos et al., 2005). Although most of the effects of Ang II related to cardiac remodeling have been attributed to the AT1 receptor, the AT2 receptor is also involved in the development of some cardiac hypertrophy models (D'Amore et al., 2005; Senbonmatsu et al., 2000; Senbonmatsu et al., 2003). In this context, blockade of the AT2 receptor attenuates the cardiac growth mediated by THs, suggesting that this receptor is also an important mediator of the hypertrophic effects exerted by THs on the heart. In addition, the AT2 receptor mediates the increase in TGF- $\beta 1$ levels observed in hyperthyroidism (Diniz et al., 2007), which may be involved in the development of cardiac hypertrophy seen in this model.

Understanding of the crosstalk between the RAS and THs is far from complete and it is important to consider that the exact mechanisms by which RAS is implicated as a key mediator of cardiac hypertrophy induced by elevated TH levels have not yet been fully identified. Evidence suggests that intracellular $\mathrm{Ca}^{2+}$ overload may play an important role in the myocardial hypertrophy induced by THs, since ACE inhibition and AT1 receptor blockade can have beneficial effects on hyperthyroid myocardial hypertrophy by altering intracellular calcium handling (Su et al., 2008).

A reduction of TH levels is also able to modulate local RAS, present in the heart. In experimental hypothyroidism, although no change had been observed in cardiac or plasma Ang II levels, the AT1 and AT2 receptors levels were increased in the heart of hypothyroid animals mainly in the right ventricle (Carneiro-Ramos et al., 2007). Whether the increase in AT1 and AT2 receptor levels observed in hypothyroidism corresponds to an alternative mechanism to compensate the atrophic state of the heart or whether it may represent a potential means to the progression of heart failure remains unknown, and future studies are needed to examine these important questions.

The modulation of some of the recently described components of the RAS by thyroid status has been investigated by our group. The findings obtained demonstrate that cardiac levels of Ang (1-7) and 
Mas are increased in TH-induced cardiac hypertrophy (personal data unpublished). On the other hand, in experimental hypothyroidism the cardiac Ang (1-7) levels and ACE2 expression are reduced, suggesting that $\mathrm{TH}$ levels are also able to influence some of the 'new' RAS components. Considering the pathophysiological and clinical implications of the novel concept of the RAS, in which the ACE2/Ang 1-7/Mas system is beginning to be viewed as the main counter-regulatory mechanism for the main axis ACE/Ang II/AT1R, it is possible that the modulation of the cardiac Ang 1-7 and Mas evidenced in hyperthyroidism may be acting as a counter-regulatory mechanism during the TH-mediated cardiac hypertrophy. This is an important question, which should be further investigated.

Taking into account that $\mathrm{TH}$ exerts several effects on hemodynamic parameters, as well as on other endocrine systems, which may influence the modulation of RAS, some recent in vitro studies have employed cardiomyocyte cultures to evaluate the influence of THs on the local RAS, present in these cells. Investigation of the possible involvement of THs in the mechanisms associated with the generation, secretion and degradation of locally synthesized Ang II is important in order to determine their hypertrophic effect in cardiomyocytes (Aras et al., 2007).

TH effects on the cardiac myocyte are intimately associated with cardiac function via regulation of the expression of key structural and regulatory genes. In this context, THs have been shown to stimulate a rapid increase in Angiotensin I/II and AT1 receptor levels in cultured cardiomyocytes (Diniz et al., 2009), as well as raising Ang I and Ang II levels in the culture medium of cardiomyocytes (personal data unpublished). Considering that Ang II stimulates cardiomyocyte growth, it is possible that higher Ang II levels in the culture medium could be binding to AT1 receptors and consequently contributing to the hypertrophic effect promoted by TH on these cells. Whether the higher Ang II levels are critical for the hypertrophic effects of TH on cardiomyocytes remains to be resolved. However, we have recently demonstrated that silencing of the AT1 receptor using a small interfering RNA completely abolished TH-induced cardiomyocyte hypertrophy, as well as TH-induced activation of the Akt/GSK3- $\beta /$ mTOR signaling pathway (Diniz et al., 2009). Considering that the PI3K/Akt/ mTOR pathway acts as a key regulator of the TH-induced cardiomyocyte hypertrophy (Kenessey and Ojamaa, 2006; Kuzman et al., 2007), it is possible that the activation of these kinases, mediated by the AT1 receptor, may be involved in $\mathrm{TH}$-induced cardiomyocyte hypertrophy, since the AT1 receptor silencing blocked the TH-induced activation of the Akt/mTOR, as well as the development of TH-induced cardiomyocyte hypertrophy.

These recent findings indicate that the local RAS, present in the cardiomyocytes, is a critical determinant of the hypertrophy promoted by HT, suggesting a new insight into the mechanism of hyperthyroidism-induced cardiac hypertrophy.

\section{Interaction of THs and vascular RAS}

Alterations in TH levels have a profound impact on the systemic vascular resistance (SVR), as mentioned previously. Although it is well known that hyperthyroidism leads to decreased SVR, the mechanism involved in this event is incompletely understood. A rapid decrease in SVR has been observed after acute TH administration in experimental animals and humans, even before changes in heart rate or cardiac contractility (Kapitola and Vilimovska, 1981; Klemperer et al., 1995; Graettinger et al., 1959). Such rapid vascular relaxation cannot be explained by the classical action of THs, which occurs by activation of nuclear TRs; however, the more rapid effects of THs may occur nongenomically (Davis and Davis, 1996). In this context, some reports have described nongenomic actions of THs in the vascular system. For example, Yoneda et al. (1998) demonstrated that a bolus injection of T3 or T4 promotes a rapid vasodilation of rat coronary artery. In contrast, a loss of the nongenomic vasodilating action of $\mathrm{TH}$, and atherosclerosis attributable to hypercholesterolemia (Hak et al., 2000), has been associated with the increased SVR seen in hypothyroidism (Klein and Ojamaa, 2001).

Another point of discussion concerning mechanisms of vascular action of THs is whether the vascular relaxation occurs due to indirect and/or direct effects of THs. Despite accumulating evidence showing that $\mathrm{TH}$ effects on the vascular system occur as indirect consequences of thermogenic or hemodynamic derangements, recent studies confirm that endothelial (ECs) and vascular smooth muscle cells (VSMCs) are potential targets of $\mathrm{TH}$ direct action and both play pivotal roles in modulating vascular tone. For example, T3 modulation of endothelium-dependent vasodilatation has been demonstrated by in vitro studies with vascular rings (Park et al., 1997; Krasner et al., 1997; McAllister et al., 1998). In humans, studies showed that the endothelium-dependent arterial dilatation is increased in hyperthyroid patients; however, after subtotal thyroidectomy this dilatation was decreased markedly (Guang-da X et al., 2004). Some data have suggested that the marked vasodilatation may be due to excess nitric oxide (NO) production by ECs together with an exaggeration of vascular reactivity (Napoli et al., 2007). Such an increase in endothelial NO production may result, in part, from T3 effects on the protein kinase Akt pathway mediated via either nongenomic or genomic mechanisms (Hiroi et al., 2006; Kuzman et al., 2005). Nitric oxide synthesized in ECs then acts in a paracrine manner on adjacent VSMCs to facilitate vascular relaxation.

Although it is known that the THs also can promote vascular relaxation through a direct action on the VSMCs (Ojamaa et al., 1996), few studies focus on contraction and relaxation independent from the effects of the endothelium. We recently demonstrated that vascular relaxation promoted by $\mathrm{T} 3$ occurs as a consequence of $\mathrm{NO}$ production by VSMCs (Carrillo-Sepulveda et al., 2009). Furthermore, our findings showed for the first time that the PI3K/Akt signaling pathway plays a role in T3-induced NO production by VSMCs, which involves the marked participation of inducible and neuronal nitric oxide synthase (NOS).

In addition to observations in other tissues, some cardiovascular effects of THs have been partly elucidated through the relationship between THs and the vascular RAS. A recent study demonstrated for the first time that T3 promotes a downregulation of vascular AT1 receptor expression, which attenuates the biological function of Ang II (Fukuyama et al., 2003). Although extremely high concentrations of TH had been used in this study and high passages of VSMCs, the authors suggested that antiatherosclerotic and vasodilatory effects of T3 could be due to a decreased AT1 receptor expression, speculating that THs may be negative regulators of the RAS. Recent data from our laboratory also support the existence of crosstalk between vascular RAS and T3 signaling in VSMCs. However, our findings showed that T3 causes upregulation of the AT2 receptor in the aorta from hyperthyroid rats and in VSMC cultures treated with pharmacological doses, suggesting that enhanced AT2 receptor expression may mediate, at least in part, the vasodilation observed in hyperthyroidism (personal data unpublished).

In conclusion, the cardiovascular effects of THs involve a complex and multifactorial process in which the RAS appears to play an integral role in the local mediation of functional and structural changes in the cardiac tissue and vasculature. A greater understanding of the functioning of the RAS in disorders of the thyroid will presumably facilitate the evolution of newer, targeted therapies.

\section{Influence of THs on the modulation of RAS in fetal and neonatal periods}

Over the past decade, there has been increasing evidence supporting the concept that adverse factors in the perinatal environment predispose an individual to disease later in life. Changes in the fetal physiological, neuroendocrine or metabolic environment may result in permanent reprogramming of the developmental pattern of 
cellular proliferation and differentiation, leading to alterations in organ physiology, morphology and/or metabolism in adult life (Robillard and Segar, 2006).

Activity of the fetal RAS is developmentally regulated, increasing in late gestation toward term. Previous studies have suggested that THs influence maturation of the RAS and cardiovascular function in the late-gestation fetus, indicating the great importance of TH levels during early life. One recent study demonstrated that THs modulate renin and Ang II receptor expression in fetal sheep (Chen et al., 2005), while the replacement of THs in hypothyroid sheep fetuses can restore renal Ang II receptor and renin expression and secretion to normal (Chen et al., 2007), suggesting that THs play a critical role in the maturation of the RAS during the fetal period. However, it remains unknown whether the modulation of RAS components by TH levels during fetal development would result in cardiovascular complications in adult life.

Furthermore, considering that the THs are involved in the control of several RAS components and are necessary for the normal morphofunctional development of the newborn, some studies have been performed to investigate the possible implications of neonatal $\mathrm{TH}$ deficiency. The findings indicate that $\mathrm{TH}$ deficiency does not directly affect renal renin expression during the critical period for normal morpho-functional development in the newborn (Montiel et al., 1999). On the other hand, there is evidence that the THs are involved in the postnatal rise in plasma ACE levels (Costerousse et al., 1994), while the serum ACE levels are reduced in children with congenital hypothyroidism (Letizia et al., 1994). Therefore, TH deficiency in early life can have important consequences for the postnatal induction of the RAS components, which may be essential for the regulation of blood pressure, and for fluid and electrolyte balance in developing rats (Matilla et al., 1993). Future studies are required to determine the potential implications of TH levels in early life and the development of cardiovascular diseases in adult life.

\section{References}

Aras, O., Messina, S.A., Shirani, J., Eckelman, W.C., Dilsizian, V., 2007. The role and regulation of cardiac angiotensin-converting enzyme for noninvasive molecular imaging in heart failure. Curr. Cardiol. Rep. 9, 150-158.

Asahi, T., Shimabukuro, M., Oshiro, Y., Yoshida, H., Takasu, N., 2001. Cilazapril prevents cardiac hypertrophy and postischemic myocardial dysfunction in hyperthyroid rats. Thyroid 11, 1009-1015.

Bader, M., Ganten, D., 2008. Update on tissue renin-angiotensin systems. J. Mol. Med. $86,615-621$.

Basset, A., Blanc, J., Messas, E., Hagege, A., Elghozi, J.L., 2001. Renin-angiotensin system contribution to cardiac hypertrophy in experimental hyperthyroidism: an echocardiographic study. J. Cardiovasc. Pharmacol. 37, 163-172.

Bomback, A.S., Toto, R., 2009. Dual blockade of the renin-angiotensin-aldosterone system: beyond the ACE inhibitor and angiotensin-II receptor blocker combination. Am. J. Hypertens. doi:10.1038/ajh.2009.138.

Bouhnik, J., Galen, F.X., Clauser, E., Menard, J., Corvol, P., 1981. The renin-angiotensin system in thyroidectomized rats. Endocrinology 108, 647-650.

Brent, G.A., 1994. The molecular basis of thyroid hormone action. N. Engl. J. Med. 331, 847-853.

Carneiro-Ramos, M.S., Silva, V.B., Santos, R.A., Barreto-Chaves, M.L., 2006. Tissuespecific modulation of angiotensin-converting enzyme (ACE) in hyperthyroidism. Peptides 27, 2942-2949.

Carneiro-Ramos, M.S., Diniz, G.P., Almeida, J., Vieira, R.L., Pinheiro, S.V., Santos, R.A., Barreto-Chaves, M.L., 2007. Cardiac angiotensin II type I and type II receptors are increased in rats submitted to experimental hypothyroidism. J. Physiol. 583, 213-223.

Carrillo-Sepulveda, M.A., Ceravolo, G.S., Fortes, Z.B., Carvalho, M.H., Tostes, R., Laurindo, F.R., Webb, R.C., Barreto-Chaves, M.L., 2009. Thyroid hormone stimulates nitric oxide production via activation of the phosphatidylinositol-3-kinase/Akt pathway in vascular myocytes. Cardiovasc. Res. doi:10.1093/cvr/cvp304.

Chen, K., Carey, L.C., Valego, N.K., Liu, J., Rose, J.C., 2005. Thyroid hormone modulates renin and ANG II receptor expression in fetal sheep. Am. J. Physiol. Regul. Integr. Comp. Physiol. 289, R1006-R1014.

Chen, K., Carey, L.C., Valego, N.K., Rose, J.C., 2007. Thyroid hormone replacement normalizes renal renin and angiotensin receptor expression in thyroidectomized fetal sheep. Am. J. Physiol. Regul. Integr. Comp. Physiol. 293, R701-R706.

Costerousse, O., Allegrini, J., Huang, H., Bounhik, J., Alhenc-Gelas, F., 1994. Regulation of ACE gene expression and plasma levels during rat postnatal development. Am. J. Physiol. 267, E745-E753.
Cristovam, P.C., Arnoni, C.P., de Andrade, M.C., Casarini, D.E., Pereira, L.G., Schor, N Boim, M.A., 2008. ACE-dependent and chymase-dependent angiotensin II generation in normal and glucose-stimulated human mesangial cells. Exp. Biol. Med. (Maywood). 233, 1035-1043.

D'Amore, A., Black, M.J., Thomas, W.G., 2005. The angiotensin II type 2 receptor causes constitutive growth of cardiomyocytes and does not antagonize angiotensin II type 1 receptor-mediated hypertrophy. Hypertension 46, 1347-1354.

Danser, A.H., 1996. Local renin-angiotensin systems. Mol. Cell. Biochem. 157, 211-216 Davis, P.J., Davis, F.B., 1996. Nongenomic actions of thyroid hormone. Thyroid 6, 497-504 Davis, P.J., Davis, F.B., 2002. Nongenomic actions of thyroid hormone on the heart Thyroid 12, 459-466.

Diniz, G.P., Carneiro-Ramos, M.S., Barreto-Chaves, M.L., 2007. Angiotensin type 1 (AT1) and type 2 (AT2) receptors mediate the increase in TGF-beta1 in thyroid hormoneinduced cardiac hypertrophy. Pflugers. Arch. 454, 75-81.

Diniz, G.P., Carneiro-Ramos, M.S., Barreto-Chaves, M.L., 2009. Angiotensin type 1 receptor mediates thyroid hormone-induced cardiomyocyte hypertrophy through the Akt/GSK-3beta/mTOR signaling pathway. Basic. Res. Cardiol. doi:10.1007/ s00395-009-0043-1.

Donoghue, M., Hsieh, F., Baronas, E., Godbout, K., Gosselin, M., Stagliano, N., Donovan, M., Woolf, B., Robison, K., Jeyaseelan, R., Breitbart, R.E., Acton, S., 2000. A nove angiotensin-converting enzyme-related carboxypeptidase (ACE2) converts angiotensin I to angiotensin 1-9. Circ. Res. 87, E1-E9.

Dzau, V.J., Re, R., 1994. Tissue angiotensin system in cardiovascular medicine. A paradigm shift? Circulation 89, 493-498.

Elias, A.N., Kyaw, T., Valenta, L.J., Meshkinpour, H., 1986. The renin-angiotensin system in hypothyroidism of short duration. Horm. Metab. Res. 18, 349-351.

Fukuyama, K., Ichiki, T., Takeda, K., Tokunou, T., Iino, N., Masuda, S., Ishibashi, M., Egashira, K., Shimokawa, H., Hirano, K., Kanaide, H., Takeshita, A., 2003. Downregulation of vascular angiotensin II type 1 receptor by thyroid hormone. Hypertension 41, 598-603.

Ganong, W.F., 1982. Thyroid hormones and renin secretion. Life. Sci. 30, 561-569.

Gotoh, M., Mizuno, K., Matsui, J., Kunii, N., Fukuchi, S., 1984. Serum angiotensin converting enzyme activity in patients with hyperthyroidism and hypothyroidism: relation to renin and aldosterone. Nippon. Naibunpi. Gakkai. Zasshi. 60, 835-845.

Goulart da Silva, F., Giannocco, G., Santos, M.F., Nunes, M.T., 2006. Thyroid hormone induction of actin polymerization in somatotrophs of hypothyroid rats: potential repercussions in growth hormone synthesis and secretion. Endocrinology 147, 5777-5785.

Graettinger, J.S., Muenster, J.J., Selverstone, L.A., Campbell, J.A., 1959. A correlation of clinical and hemodynamic studies in patients with hyperthyroidism with and without congestive heart failure. J. Clin. Invest. 38, 1316-1327.

Guang-da, X., Hong-yan, C., Xian-mei, Z., 2004. Changes in endothelium-dependent arterial dilation before and after subtotal thyroidectomy in subjects with hyperthyroidism. Clin. Endocrinol. (Oxf) 61, 400-404.

Hak, A.E., Pols, H.A., Visser, T.J., Drexhage, H.A., Hofman, A., Witteman, J.C., 2000. Subclinical hypothyroidism is an independent risk factor for atherosclerosis and myocardial infarction in elderly women: the Rotterdam Study. Ann. Intern. Med. $132,270-278$

Hiroi, Y., Kim, H.H., Ying, H., Furuya, F., Huang, Z., Simoncini, T., Noma, K., Ueki, K., Nguyen, N.H., Scanlan, T.S., Moskowitz, M.A., Cheng, S.Y., Liao, J.K., 2006. Rapid nongenomic actions of thyroid hormone. Proc. Natl. Acad. Sci. USA. 103, 14104-14109.

Hong-Brown, L.Q., Deschepper, C.F., 1992. Effects of thyroid hormones on angiotensinogen gene expression in rat liver, brain, and cultured cells. Endocrinology 130, 1231-1237.

Hu, L.W., Benvenuti, L.A., Liberti, E.A., Carneiro-Ramos, M.S., Barreto-Chaves, M.L., 2003 Thyroxine-induced cardiac hypertrophy: influence of adrenergic nervous system versus renin-angiotensin system on myocyte remodeling. Am. J. Physiol. Regul. Integr. Comp. Physiol. 285, R1473-R1480.

Jimenez, E., Montiel, M., Narvaez, J.A., Morell, M., 1984. Renin-angiotensin system in hypothyroid rats: effects of potassium iodide and triiodo-L-thyronine. Acta. Endocrinol. (Copenh) 105, 505-510.

Kahaly, G.J., Dillmann, W.H., 2005. Thyroid hormone action in the heart. Endocr. Rev. 26, 704-728.

Kapitola, J., Vilimovska, D., 1981. Inhibition of the early circulatory effects of triiodothyronine in rats by propranolol. Physiol. Bohemoslov. 30, 347-351.

Kenessey, A., Ojamaa, K., 2006. Thyroid hormone stimulates protein synthesis in the cardiomyocyte by activating the Akt-mTOR and p70S6K pathways. J. Biol. Chem. 281, 20666-20672.

Klein, I., Danzi, S., 2007. Thyroid disease and the heart. Circulation 116, 1725-1735.

Klein, I., Ojamaa, K., 2001. Thyroid hormone and the cardiovascular system. N. Engl. J. Med. 344, 501-509.

Klemperer, J.D., Klein, I., Gomez, M., Helm, R.E., Ojamaa, K., Thomas, S.J., Isom, O.W. Krieger, K., 1995. Thyroid hormone treatment after coronary-artery bypass surgery. N. Engl. J. Med. 333, 1522-1527.

Kobori, H., Ichihara, A., Suzuki, H., Miyashita, Y., Hayashi, M., Saruta, T., 1997a. Thyroid hormone stimulates renin synthesis in rats without involving the sympathetic nervous system. Am. J. Physiol. 272, E227-E232.

Kobori, H., Ichihara, A., Suzuki, H., Takenaka, T., Miyashita, Y., Hayashi, M., Saruta, T., 1997b. Role of the renin-angiotensin system in cardiac hypertrophy induced in rats by hyperthyroidism. Am. J. Physiol. 273, H593-H599.

Krasner, L.J., Wendling, W.W., Cooper, S.C., Chen, D., Hellmann, S.K., Eldridge, C.J. McClurken, J.B., Jeevanandam, V., Carlsson, C., 1997. Direct effects of triiodothyronine on human internal mammary artery and saphenous veins. J. Cardiothorac. Vasc. Anesth. 11, 463-466.

Kumar, R., Singh, V.P., Baker, K.M., 2007. The intracellular renin-angiotensin system: a new paradigm. Trends. Endocrinol. Metab. 18, 208-214. 
Kuzman, J.A., Gerdes, A.M., Kobayashi, S., Liang, Q., 2005. Thyroid hormone activates Akt and prevents serum starvation-induced cell death in neonatal rat cardiomyocytes. J. Mol. Cell. Cardiol. 39, 841-844.

Kuzman, J.A., O'Connell, T.D., Gerdes, A.M., 2007. Rapamycin prevents thyroid hormone-induced cardiac hypertrophy. Endocrinology 148, 3477-3484.

Lavoie, J.L., Sigmund, C.D., 2003. Minireview: overview of the renin-angiotensin system-an endocrine and paracrine system. Endocrinology 144, 2179-2183.

Lavrentyev, E.N., Estes, A.M., Malik, K.U., 2007. Mechanism of high glucose induced angiotensin II production in rat vascular smooth muscle cells. Circ. Res. 101, 455-464.

Letizia, C., Centanni, M., De Ciocchis, A., Pontecorvi, A., Cerci, S., Vermiglio, F, Scaramazza, U., Scavo, D., 1994. Reduced serum angiotensin converting enzyme activity in children with congenital hypothyroidism. Horm. Metab. Res. 26, 243-245.

Marchant, C., Brown, L., Sernia, C., 1993. Renin-angiotensin system in thyroid dysfunction in rats. J. Cardiovasc. Pharmacol. 22, 449-455.

Matilla, M.J., Montiel, M., Jimenez, E., 1993. Angiotensin II (AII) and adrenal gland AI receptors in rats with congenital hypothyroidism. J. Endocrinol. 137, 231-238.

McAllister, R.M., Grossenburg, V.D., Delp, M.D., Laughlin, M.H., 1998. Effects of hyperthyroidism on vascular contractile and relaxation responses. Am. J. Physiol. 274, E946-E953.

Montiel, M., Jimenez, E., Navaez, J.A., Morell, M., 1984. Aldosterone and plasma renin activity in hyperthyroid rats: effects of propranolol and propylthiouracil. J. Endocrinol. Invest. 7, 559-562

Montiel, M., Diaz, F., Quesada, J., Jimenez, E., 1999. Ontogeny of renal renin in congenital hypothyroid rats. Life. Sci. 65, 263-269.

Napoli, R., Guardasole, V., Angelini, V., Zarra, E., Terracciano, D., D'Anna, C., Matarazzo, M., Oliviero, U., Macchia, V., Sacca, L., 2007. Acute effects of triiodothyronine on endothelial function in human subjects. J. Clin. Endocrinol. Metab. 92, 250-254.

Ojamaa, K., Klemperer, J.D., Klein, I., 1996. Acute effects of thyroid hormone on vascular smooth muscle. Thyroid 6, 505-512.

Pantos, C., Paizis, I., Mourouzis, I., Moraitis, P., Tzeis, S., Karamanoli, E., Mourouzis, C. Karageorgiou, H., Cokkinos, D.V., 2005. Blockade of angiotensin II type 1 receptor diminishes cardiac hypertrophy, but does not abolish thyroxin-induced preconditioning. Horm. Metab. Res. 37, 500-504.

Park, K.W. Dai, H.B., Ojamaa, K., Lowenstein, E, Klein, I, Sellke, FW. 1997. The direct vasomotor effect of thyroid hormones on rat skeletal muscle resistance arteries. Anesth. Analg. 85, 734-738.
Paul, M., Poyan Mehr, A., Kreutz, R., 2006. Physiology of local renin-angiotensin systems. Physiol. Rev. 86, 747-803.

Robillard, J.E., Segar, J.L., 2006. Influence of early life events on health and diseases. Trans. Am. Clin. Climatol. Assoc. 117, 319-320.

Santos, R.A., Simoes e Silva, A.C., Maric, C., Silva, D.M., Machado, R.P., de Buhr, I, Heringer-Walther, S., Pinheiro, S.V., Lopes, M.T., Bader, M., Mendes, E.P., Lemos, V.S., Campagnole-Santos, M.J., Schultheiss, H.P., Speth, R., Walther, T., 2003. Angioten$\sin -(1-7)$ is an endogenous ligand for the $G$ protein-coupled receptor Mas. Proc. Natl. Acad. Sci. U.S.A. 100, 8258-8263.

Santos, R.A., Ferreira, A.J., Simoes, E.S.A.C., 2008. Recent advances in the angiotensinconverting enzyme 2-angiotensin(1-7)-Mas axis. Exp. Physiol. 93, 519-527.

Schluter, K.D., Wenzel, S., 2008. Angiotensin II: a hormone involved in and contributing to pro-hypertrophic cardiac networks and target of anti-hypertrophic cross-talks. Pharmacol. Ther. 119, 311-325.

Senbonmatsu, T. Ichihara, S., Price Jr., E. Gaffney, F.A., Inagami, T, 2000. Evidence for angiotensin II type 2 receptor-mediated cardiac myocyte enlargement during in vivo pressure overload. J. Clin. Invest. 106, R25-R29.

Senbonmatsu, T., Saito, T., Landon, E.J., Watanabe, O., Price Jr., E., Roberts, R.L., Imboden, H., Fitzgerald, T.G., Gaffney, F.A., Inagami, T., 2003. A novel angiotensin II type 2 receptor signaling pathway: possible role in cardiac hypertrophy. Embo. J. 22, 6471-6482.

Sernia, C., Marchant, C., Brown, L., Hoey, A., 1993. Cardiac angiotensin receptors in experimental hyperthyroidism in dogs. Cardiovasc. Res. 27, 423-428.

Su, L., Dai, Y., Deng, W., Yin, Y.H., 2008. Renin-angiotensin system blocking agents reverse the myocardial hypertrophy in experimental hyperthyroid cardiomyopathy via altering intracellular calcium handling. Zhonghua. Xin. Xue. Guan. Bing. Za. Zhi. 36, 744-749.

Tipnis, S.R., Hooper, N.M., Hyde, R., Karran, E., Christie, G., Turner, A.J., 2000. A human homolog of angiotensin-converting enzyme. Cloning and functional expression as a captopril-insensitive carboxypeptidase. J. Biol. Chem. 275, 33238-33243.

Yoneda, K., Takasu, N., Higa, S., Oshiro, C., Oshiro, Y., Shimabukuro, M., Asahi, T., 1998. Direct effects of thyroid hormones on rat coronary artery: nongenomic effects of triiodothyronine and thyroxine. Thyroid 8, 609-613.

Zdrojewicz, Z., 1991. Plasma renin activity in women with hyperthyroidism. Pol. Arch. Med. Wewn. 86, 101-106.

Zdrojewicz, Z., Plamieniak, Z., 1993. Plasma renin activity in women with hypothyroidism. Pol. Tyg. Lek. 48, 595-598. 
ANEXO B 


\title{
Angiotensin type 1 receptor mediates thyroid hormone-induced cardiomyocyte hypertrophy through the Akt/GSK-3//mTOR signaling pathway
}

\author{
Gabriela Placoná Diniz . \\ Marcela Sorelli Carneiro-Ramos • \\ Maria Luiza Morais Barreto-Chaves
}

Received: 5 March 2009/Revised: 17 June 2009/Accepted: 19 June 2009/Published online: 9 July 2009

(C) Springer-Verlag 2009

\begin{abstract}
Several studies have implicated the renin angiotensin system in the cardiac hypertrophy induced by thyroid hormone. However, whether Angiotensin type 1 receptor $\left(\mathrm{AT}_{1} \mathrm{R}\right)$ is critically required to the development of $\mathrm{T}_{3}$-induced cardiomyocyte hypertrophy as well as whether the intracellular mechanisms that are triggered by $\mathrm{AT}_{1} \mathrm{R}$ are able to contribute to this hypertrophy model is unknown. To address these questions, we employed a selective small interfering RNA (siRNA, $50 \mathrm{nM}$ ) or an $\mathrm{AT}_{1} \mathrm{R}$ blocker (Losartan, $1 \mu \mathrm{M}$ ) to evaluate the specific role of this receptor in primary cultures of neonatal cardiomyocytes submitted to $\mathrm{T}_{3}(10 \mathrm{nM})$ treatment. The cardiomyocytes transfected with the $\mathrm{AT}_{1} \mathrm{R}$ siRNA presented reduced mRNA $(90 \%, P<0.001)$ and protein (70\%, $P<0.001)$ expression of $\mathrm{AT}_{1} \mathrm{R}$. The $\mathrm{AT}_{1} \mathrm{R}$ silencing and the $\mathrm{AT}_{1} \mathrm{R}$ blockade totally prevented the $\mathrm{T}_{3}$-induced cardiomyocyte hypertrophy, as evidenced by lower mRNA expression of atrial natriuretic factor $(66 \%$, $P<0.01)$ and skeletal $\alpha$-actin $(170 \%, P<0.01)$ as well as by reduction in protein synthesis $(85 \%, P<0.001)$. The cardiomyocytes treated with $\mathrm{T}_{3}$ demonstrated a rapid activation of Akt/GSK-3 $\beta / \mathrm{mTOR}$ signaling pathway, which was completely inhibited by the use of PI3K inhibitors (LY294002, $10 \mu \mathrm{M}$ and Wortmannin, $200 \mathrm{nM}$ ).
\end{abstract}

G. P. Diniz · M. L. M. Barreto-Chaves $(\bowtie)$

Laboratory of Cellular Biology and Functional Anatomy, Department of Anatomy, Institute of Biomedical Sciences, University of São Paulo, Av. Prof. Lineu Prestes 2415,

São Paulo, SP 05508-900, Brazil

e-mail: mchaves@usp.br

M. S. Carneiro-Ramos

Department of Cell and Developmental Biology,

Institute of Biomedical Sciences, University of São Paulo,

São Paulo 05508-900, Brazil
In addition, we demonstrated that the $\mathrm{AT}_{1} \mathrm{R}$ mediated the $\mathrm{T}_{3}$-induced activation of Akt/GSK-3 $\beta / \mathrm{mTOR}$ signaling pathway, since the $\mathrm{AT}_{1} \mathrm{R}$ silencing and the $\mathrm{AT}_{1} \mathrm{R}$ blockade attenuated or totally prevented the activation of this signaling pathway. We also reported that local Angiotensin I/II (Ang I/II) levels $(120 \%, P<0.05)$ and the $\mathrm{AT}_{1} \mathrm{R}$ expression $(180 \%, P<0.05)$ were rapidly increased by $\mathrm{T}_{3}$ treatment. These data demonstrate for the first time that the $\mathrm{AT}_{1} \mathrm{R}$ is a critical mediator to the $\mathrm{T}_{3}$-induced cardiomyocyte hypertrophy as well as to the activation of Akt/GSK$3 \beta /$ mTOR signaling pathway. These results represent a new insight into the mechanism of $\mathrm{T}_{3}$-induced cardiomyocyte hypertrophy, indicating that the Ang I/II-AT ${ }_{1} \mathrm{R}-\mathrm{Akt} /$ GSK-3 $\beta /$ mTOR pathway corresponds to a potential mediator of the trophic effect exerted by $\mathrm{T}_{3}$ in cardiomyocytes.

Keywords Angiotensin II type 1 receptor .

Thyroid hormone - Cardiomyocyte .

Akt/GSK-3 $\beta /$ mTOR signaling pathway $\cdot$ Hypertrophy

\section{Introduction}

Cardiac hypertrophy and heart failure, which are influenced by several factors, correspond to principal causes of morbidity and mortality in Western societies [26]. Thyroid hormone $(\mathrm{TH})$ metabolic disarray, as occurs in hyperthyroidism, has been shown to be a major risk factor for the progression of these cardiac diseases [53]. Recent studies have revealed novel mechanisms of action of TH on the heart which may be of important physiological and therapeutic relevance. Apart from its "classical" actions on cardiac contractility and heart rhythm [14], TH regulates multiple signaling pathways [49], including the phosphoinositide 3-kinase/Akt/glycogen synthase kinase-3beta/ 
mammalian target of rapamycin (PI3K/Akt/GSK-3 $\beta$ / mTOR) pathway, which has been shown to modulate cardiomyocyte hypertrophy in vivo and in vitro $[33,34,36$, 37]. In addition, recently, the activation of Akt has been considered to be a common feature of the cardioprotective mechanisms of numerous peptide hormones and growth factors [41]. In fact, TH-induced hypertrophy is phenotypically similar to the physiological hypertrophy, and the activation of Akt signaling has been considered as an important mediator of this process [10, 30].

We and other authors have recently described a close relationship between $\mathrm{TH}$ action and the renin angiotensin system (RAS) [7, 8, 16, 29, 31, 32], since the use of pharmacologic blockade of angiotensin-converting enzyme (ACE) or Angiotensin II (Ang II) type 1 receptor $\left(\mathrm{AT}_{1} \mathrm{R}\right)$ prevented the cardiac hypertrophy promoted by TH [29]. It is now clear that RAS acts globally to control the cardiovascular system, and that RAS components act locally within individual organs and under differential regulation [2]. Then, in addition to well-known actions, circulating and locally generated Ang II exert other non-hemodynamic effects, stimulating cardiomyocyte growth and fibrosis in adult myocardium, modulating the cardiac hypertrophy process $[21,38]$. In fact, there is now accumulating evidence that this peptide has important paracrine/autocrine functions $[12,19]$. These actions are mediated mainly by binding to $\mathrm{AT}_{1} \mathrm{R}$, which has been shown to be responsible for most of the physiological and pathophysiological effects of Ang II [27], including cardiomyocyte hypertrophy and positive inotropy [59], and its intracellular signal transduction has been implicated in numerous cardiovascular diseases [27]. Through $\mathrm{AT}_{1} \mathrm{R}$, Ang II activates various intracellular protein kinases, such as members of the mitogen-activated protein kinase family, the 70-kDa ribosomal protein S6 kinase (p70S6K), different protein kinase $\mathrm{C}$ isoforms and Akt signaling pathway [20, 25, 55, 56, 64].

Given that TH and Ang II are both able to induce cardiac hypertrophy and that both activate the Akt signaling pathway in cardiomyocytes [30,54], the aim of the present study was to evaluate the exact role of $\mathrm{AT}_{1} \mathrm{R}$ in $\mathrm{T}_{3}$-induced cardiomyocyte hypertrophy in vitro as well as in $\mathrm{T}_{3}$-induced activation of the Akt/GSK-3 $\beta / \mathrm{mTOR}$ signaling pathway. To address these questions, we used an $\mathrm{AT}_{1} \mathrm{R}-$ specific small interfering RNA ( $\mathrm{AT}_{1} \mathrm{R}$ siRNA) or the $\mathrm{AT}_{1} \mathrm{R}$ pharmacologic blockade to evaluate the role of this receptor. The modulation of Akt/GSK-3 $\beta / \mathrm{mTOR}$ signaling pathway and the participation of PI3K were also analyzed. We also evaluated the Angiotensin I/II (Ang I/II) and the $\mathrm{AT}_{1} \mathrm{R}$ levels in $\mathrm{T}_{3}$-induced cardiomyocyte hypertrophy.

Herein, we demonstrated for the first time that the $\mathrm{AT}_{1} \mathrm{R}$ mediates the ability of $\mathrm{T}_{3}$ to induce cardiomyocyte hypertrophy as well to stimulate the Akt/GSK-3 $\beta / \mathrm{mTOR}$ signaling pathway in these cells. This effect may occur in part due to increased local Ang I/II levels as well as increased $\mathrm{AT}_{1} \mathrm{R}$ expression promoted by $\mathrm{T}_{3}$ treatment. These results provide novel insights into the mechanism of $\mathrm{T}_{3}$ action that are relevant to the cardiovascular system.

\section{Results}

\section{Characterization of $\mathrm{AT}_{1} \mathrm{R}$ silencing}

Initially, transfection efficiency of siRNA was evaluated in cardiomyocytes cultures and confirmed by using confocal microscopy and flow cytometry analysis. The quantification of transfected cells indicated that more than $70 \%$ of the cardiomyocytes evaluated were successfully transfected $(P<0.01$ vs. control).

The $\mathrm{AT}_{1} \mathrm{R}$ gene silencing was validated since the cardiomyocytes cultures transfected with $\mathrm{AT}_{1} \mathrm{R}$ siRNA showed a reduction of approximately $90 \%$ in the $\mathrm{AT}_{1} \mathrm{R}$ mRNA expression (Fig. 1a), which was observed after $24 \mathrm{~h}$ of transfection and maintained until $80 \mathrm{~h}$ of transfection $\left(P<0.001\right.$ vs. control). Protein expression of $\mathrm{AT}_{1} \mathrm{R}$ was also significantly reduced in approximately $70 \%$ at $56 \mathrm{~h}$ after transfection and remained so until $80 \mathrm{~h}$ of transfection ( $P<0.001$ vs. control; Fig. 1b). To demonstrate the specificity of $\mathrm{AT}_{1} \mathrm{R}$ silencing as well as the absence of upregulation of $\mathrm{AT}_{2} \mathrm{R}$ after $\mathrm{AT}_{1} \mathrm{R}$ silencing experiments, the $\mathrm{AT}_{2} \mathrm{R}$ protein expression was also evaluated (Fig. 1c). The findings showed that after $A_{1} R$ silencing there was no compensatory change in $\mathrm{AT}_{2} \mathrm{R}$ expression. In addition, possible non-specific effects of transfection on cardiomyocytes were discarded after use of a siRNA negative control (Fig. 1d), which when transfected in the cells did not promote any alteration on $\mathrm{AT}_{1} \mathrm{R}$ expression levels.

\section{$\mathrm{AT}_{1} \mathrm{R}$ mediates $\mathrm{T}_{3}$-induced cardiomyocyte hypertrophy}

We previously reported that the in vivo pharmacologic blockade of $\mathrm{AT}_{1} \mathrm{R}$ markedly attenuates cardiac hypertrophy induced by elevated levels of TH [29]. We, therefore, ascertained whether this effect could be observed in isolated cardiomyocytes in the absence of other cell types and hemodynamic influences. Primarily, to evaluate the action of $\mathrm{T}_{3}$ inducing cardiomyocyte growth in vitro, the ANF and skeletal $\alpha$-actin mRNA levels were determined by real-time RT-PCR. These genes are markedly activated by hypertrophic stimuli in cardiomyocytes and thus are usually employed as cardiac hypertrophy markers [35, 52]. As expected, the gene expression of ANF $(475 \%, P<0.001$ vs. control), as well as that of skeletal $\alpha$-actin $(515 \%$, $P<0.001$ vs. control), was significantly higher in the cardiomyocytes treated with $\mathrm{T}_{3}$ for $24 \mathrm{~h}$, confirming the well-described hypertrophic effect of TH (Fig. 2a, b). 
Fig. $1 \mathrm{AT}_{1} \mathrm{R}$ expression of mRNA (a) and protein (b) evaluated, respectively, by realtime RT-PCR and Western blotting in cultured cardiomyocytes transfected with $50 \mathrm{nM}$ of $\mathrm{AT}_{1} \mathrm{R}$ siRNA in serum-free medium for 24,48 , 56,72 or 80 h. $A_{2} \mathrm{R}$ protein expression in cultured cardiomyocytes transfected with $50 \mathrm{nM}$ of $\mathrm{AT}_{1} \mathrm{R}$ siRNA in serum-free medium for 48,56 , 72 or $80 \mathrm{~h}(\mathbf{c}) . \mathrm{AT}_{1} \mathrm{R}$ protein expression in cultured cardiomyocytes transfected with $50 \mathrm{nM}$ of siRNA negative control (scrambled siRNA) in serum-free medium for 56,72 or $80 \mathrm{~h}$ (d). The control cells were treated with serum-free medium containing the transfection mediator. $\mathrm{AT}_{1} \mathrm{Ra}$ and $\mathrm{AT}_{1} \mathrm{Rb}$ were used for quantification of $\mathrm{AT}_{1} \mathrm{R}$ expression. $\alpha$-Actinin protein expression was used for normalization. Results are expressed as percentages. $* * * P<0.001$ vs. control. Number $(N)$ represents the different cardiomyocyte preparations $(n=3)$
A

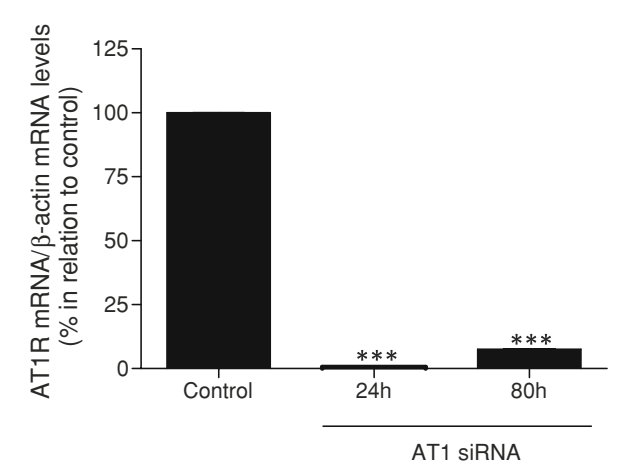

C
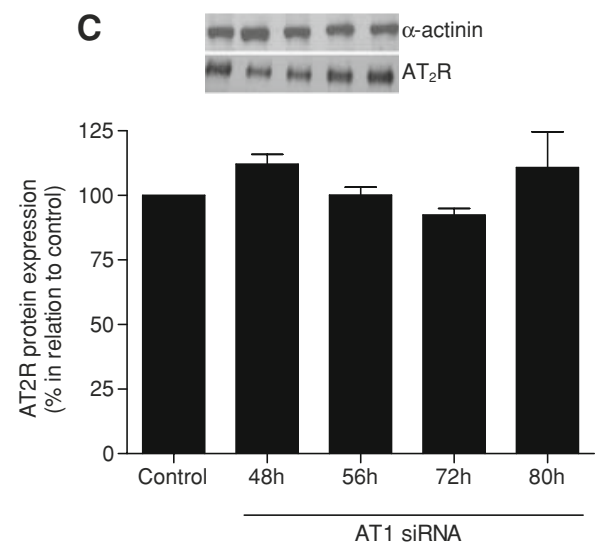

B

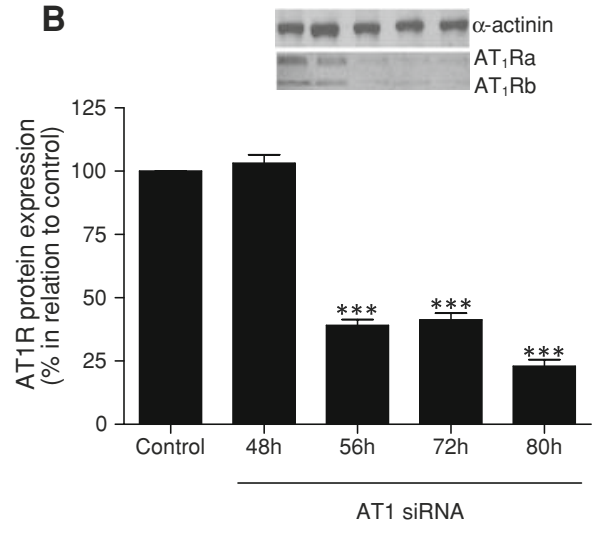

D

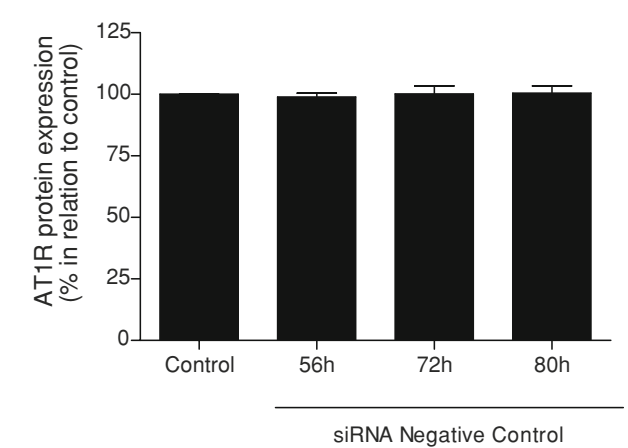

However, in those transfected with $\mathrm{AT}_{1} \mathrm{R}$ siRNA and treated with $\mathrm{T}_{3}$ for $24 \mathrm{~h}$, the expression of ANF $(66 \%$, $P<0.01$ vs. $\left.\mathrm{T}_{3}\right)$ and skeletal $\alpha$-actin $\left(170 \%, P<0.01\right.$ vs. $\left.\mathrm{T}_{3}\right)$ was significantly lower than in those only treated with $\mathrm{T}_{3}$. Moreover, the mRNA expression of ANF and skeletal $\alpha$-actin was significantly reduced ( $P<0.001$ vs. control), in approximately $90 \%$, in cardiomyocytes transfected with $\mathrm{AT}_{1} \mathrm{R}$ siRNA compared to control cells (Fig. 2a, b). Although the cardiac hypertrophy markers had been increased after $\mathrm{T}_{3}$ treatment, protein synthesis experiments were also conducted to confirm the hypertrophic effect of $\mathrm{T}_{3}$ in cell cultures (Fig. 2c). The leucine incorporation assays showed that protein synthesis was significantly increased $(400 \%, P<0.001$ vs. control) in the cardiomyocytes treated with $\mathrm{T}_{3}$ for $24 \mathrm{~h}$. However, protein synthesis was significantly lower $\left(85 \%, P<0.001\right.$ vs. $\left.\mathrm{T}_{3}\right)$ in the cardiomyocytes transfected with $\mathrm{AT}_{1} \mathrm{R}$ siRNA and treated with $\mathrm{T}_{3}$ than in those only treated with $\mathrm{T}_{3}$ (Fig. 2c). Because $\mathrm{AT}_{1} \mathrm{R}$ silencing prevented the hypertrophic effect promoted by $\mathrm{T}_{3}$, we examined whether the use of $\mathrm{AT}_{1}$ pharmacologic blockade with Losartan $(1 \mu \mathrm{M})$ would have similar effects in the cardiomyocytes. Similarly, we found that the expression of both ANF and skeletal $\alpha$-actin as well as the protein synthesis was also significantly lower $\left(P<0.001\right.$ vs. $\left.\mathrm{T}_{3}\right)$ in the cardiomyocytes treated with Losartan plus $\mathrm{T}_{3}$ than in those only treated with $\mathrm{T}_{3}$.
$\mathrm{AT}_{1} \mathrm{R}$ mediates $\mathrm{T}_{3}$-induced activation

of the Akt/GSK-3 $\beta /$ mTOR signaling pathway

It is accepted that the activation of PI3K/Akt/mTOR signaling pathway is a critical mediator of $\mathrm{TH}$-induced cardiac hypertrophy [30]. Thus, we hypothesized that $\mathrm{AT}_{1} \mathrm{R}$ may act as a mediator of $\mathrm{T}_{3}$-induced activation of this signaling pathway. Cardiomyocytes were stimulated with $\mathrm{T}_{3}(10 \mathrm{nM})$ for $0,5,10,15$ and $30 \mathrm{~min}$. Also, the effect on long term of $\mathrm{T}_{3}$ treatment on Akt activation was studied by preincubating cardiomyocytes with/without $\mathrm{T}_{3}$ for $24 \mathrm{~h}$. Thereafter, phosphorylation levels of Akt at $\mathrm{Ser}^{473}$ and $\mathrm{Thr}^{308}$ residues as well as total Akt levels were determined using Western blot analysis. Phosphorylation levels of Akt were significantly increased at $\operatorname{Ser}^{473}$ (1.5-fold, $P<0.05$ vs. control) and at $\mathrm{Thr}^{308}$ (1.7-fold, $P<0.01$ vs. control) after treatment with $\mathrm{T}_{3}$ for $5 \mathrm{~min}$ and were maintained through $30 \mathrm{~min}$ of $\mathrm{T}_{3}$ stimulation (Fig. 3a-c). Phosphorylation levels of Akt at $\mathrm{Ser}^{473}$ and at $\mathrm{Thr}^{308}$ after treatment with $\mathrm{T}_{3}$ for $24 \mathrm{~h}$ were not altered. However, surprisingly, the transfection with $\mathrm{AT}_{1} \mathrm{R}$ siRNA attenuated or totally prevented the $\mathrm{T}_{3}$-induced increase in the phosphorylation levels of Akt at $\mathrm{Ser}^{473}$ and at $\mathrm{Thr}^{308}$ (Fig. 3d-f). Unexpectedly, total Akt levels were significantly decreased ( 0.5 -fold, $P<0.01$ vs. control) in $\mathrm{AT}_{1} \mathrm{R}$ silenced cardiomyocytes (Fig. 3e). Then, the effect of 


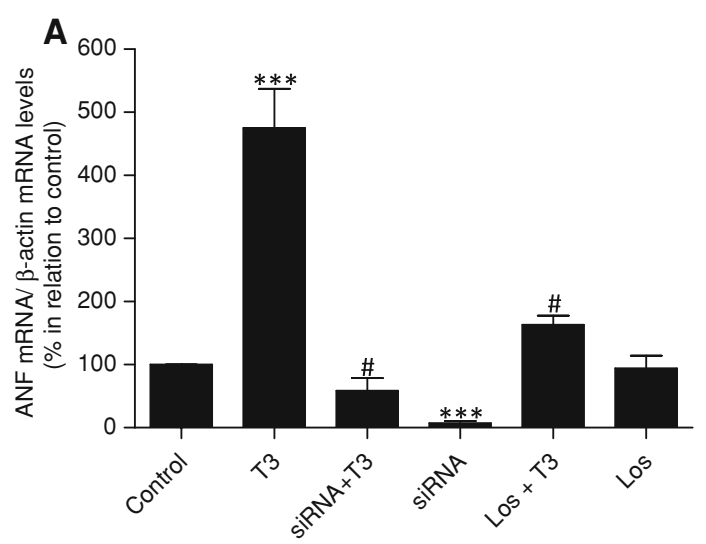

\section{B}
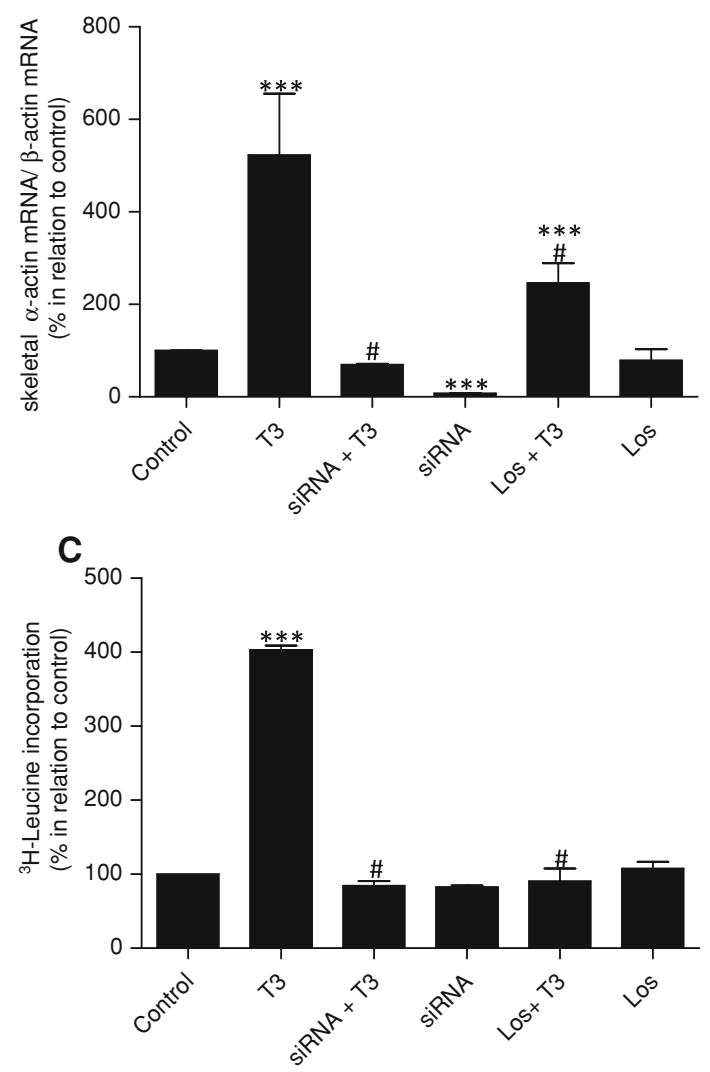

Fig. 2 ANF (a) and skeletal $\alpha$-actin (b) mRNA levels evaluated by real-time RT-PCR, in cells treated with serum-free medium containing $10 \mathrm{nM}$ of $\mathrm{T}_{3}$ for $24 \mathrm{~h}\left(\mathrm{~T}_{3}\right)$, as well as cells transfected with $50 \mathrm{nM}$ of $\mathrm{AT}_{1} \mathrm{R}$ siRNA for $56 \mathrm{~h} /$ treated with $10 \mathrm{nM}$ of $\mathrm{T}_{3}$ for $24 \mathrm{~h}$ ( siRNA $+\mathrm{T}_{3}$ ), cells transfected with $50 \mathrm{nM}$ of $\mathrm{AT}_{1} \mathrm{R}$ siRNA for $80 \mathrm{~h}$ (siRNA), cells treated with serum-free medium containing $1 \mu \mathrm{M}$ of Losartan plus $10 \mathrm{nM}$ of $\mathrm{T}_{3}$ (Los $+\mathrm{T}_{3}$ ), $1 \mu \mathrm{M}$ of Losartan (Los) for $24 \mathrm{~h}$ or only serum-free medium in control cells. ${ }^{3} \mathrm{H}$-Leucine incorporation (c) in control cells, as well as in $\mathrm{T}_{3}$, siRNA $+\mathrm{T}_{3}$, siRNA, Los $+\mathrm{T}_{3}$ and Los. Six hours before harvest, L- $\left[3,4,5-{ }^{3} \mathrm{H}\right]$ leucine $(5 \mu \mathrm{Ci} / \mathrm{ml})$ was added to the culture medium to measure incorporation into newly synthesized protein. Results are expressed as percentages. ${ }^{* * *} P<0.001$ vs. control, ${ }^{\#} P<0.01$ vs. $\mathrm{T}_{3}$. Number $(N)$ represents the different cardiomyocyte preparations $(n=3)$
$\mathrm{AT}_{1} \mathrm{R}$ blockade with Losartan on Akt activation was also evaluated. Similarly, the administration of Losartan completely prevented the $\mathrm{T}_{3}$-induced increase in the phosphorylation levels of Akt at $\mathrm{Ser}^{473}$ and at $\mathrm{Thr}^{308}$ residues (Fig. 3g-i).

In response to receptor tyrosine kinase/G protein-coupled receptor (GPCR) activation, phosphorylation of glycogen synthase kinase- $3 \beta$ (GSK3- $\beta$ ) at $\operatorname{Ser}^{9}$ in the $\mathrm{N}$-terminal region by Akt inhibits GSK3- $\beta$, thereby leading to diverse effects including hypertrophy [46]. Consistent with the changes in Akt phosphorylation, phosphorylation levels of GSK3- $\beta$ were significantly increased at $\operatorname{Ser}^{9}$ to maximal levels within 5 min (1.8-fold, $P<0.05$ vs. control) of $\mathrm{T}_{3}$ treatment that were maintained through $10 \mathrm{~min}$ of stimulation (1.8-fold, $P<0.05$ vs. control) but linearly decreased to basal values at $30 \mathrm{~min}$ (Fig. $4 \mathrm{a}-\mathrm{c}$ ). Phosphorylation levels of GSK3- $\beta$ at $\operatorname{Ser}^{9}$ were not changed after $24 \mathrm{~h}$ of $\mathrm{T}_{3}$ treatment. Similarly to the observed with Akt, the $\mathrm{T}_{3}$-induced increase in the phosphorylation levels of GSK3- $\beta$ at Ser $^{9}$ was completely prevented by transfection with $\mathrm{AT}_{1} \mathrm{R}$ siRNA (Fig. $4 \mathrm{~d}-\mathrm{f}$ ) or by $\mathrm{AT}_{1} \mathrm{R}$ blockade with Losartan (Fig. 4g-i).

Considering that Akt activation activates downstream the mammalian target of rapamycin (mTOR), also termed FRAP, via translational and phosphorylationdependent mechanisms, leading to increased growth mediated by changes in gene transcription and translation [47], we evaluated the expression of this kinase in cardiomyocytes stimulated with $\mathrm{T}_{3}(10 \mathrm{nM})$ for $0,5,10$, 15 and 30 min or $24 \mathrm{~h}$ (Fig. 5). Phosphorylation levels of mTOR at $\mathrm{Ser}^{2448}$ were significantly increased (2-fold, $P<0.01$ vs. control) to maximal levels within $10 \mathrm{~min}$ of $\mathrm{T}_{3}$ treatment and a linear decrease in the phosphorylation levels of mTOR was observed within 15 min returning to basal values (Fig. 5a-c). Again, the $\mathrm{AT}_{1} \mathrm{R}$ silencing (Fig. $5 \mathrm{~d}-\mathrm{f}$ ) or the $\mathrm{AT}_{1} \mathrm{R}$ blockade with Losartan (Fig. $5 \mathrm{~g}-\mathrm{i}$ ) completely prevented the $\mathrm{T}_{3}$-induced increase in the phosphorylation levels of mTOR. These results showed that the $\mathrm{AT}_{1} \mathrm{R}$ mediates $\mathrm{T}_{3}$-induced activation of the Akt/GSK-3 $\beta / \mathrm{mTOR}$ signaling pathway, since the $\mathrm{AT}_{1} \mathrm{R}$ silencing or the $\mathrm{AT}_{1} \mathrm{R}$ blockade attenuated or completely abolished the activation of this signaling promoted by $\mathrm{T}_{3}$.

$\mathrm{T}_{3}$-induced activation of the Akt/GSK-3 $\beta / \mathrm{mTOR}$ signaling pathway is mediated by $\mathrm{PI} 3 \mathrm{~K}$

Considering that PI3K was reported to mediate Akt activation [46], we decided to investigate the participation of $\mathrm{PI} 3 \mathrm{~K}$ in the $\mathrm{T}_{3}$-induced activation of the Akt/GSK-3 $\beta /$ 

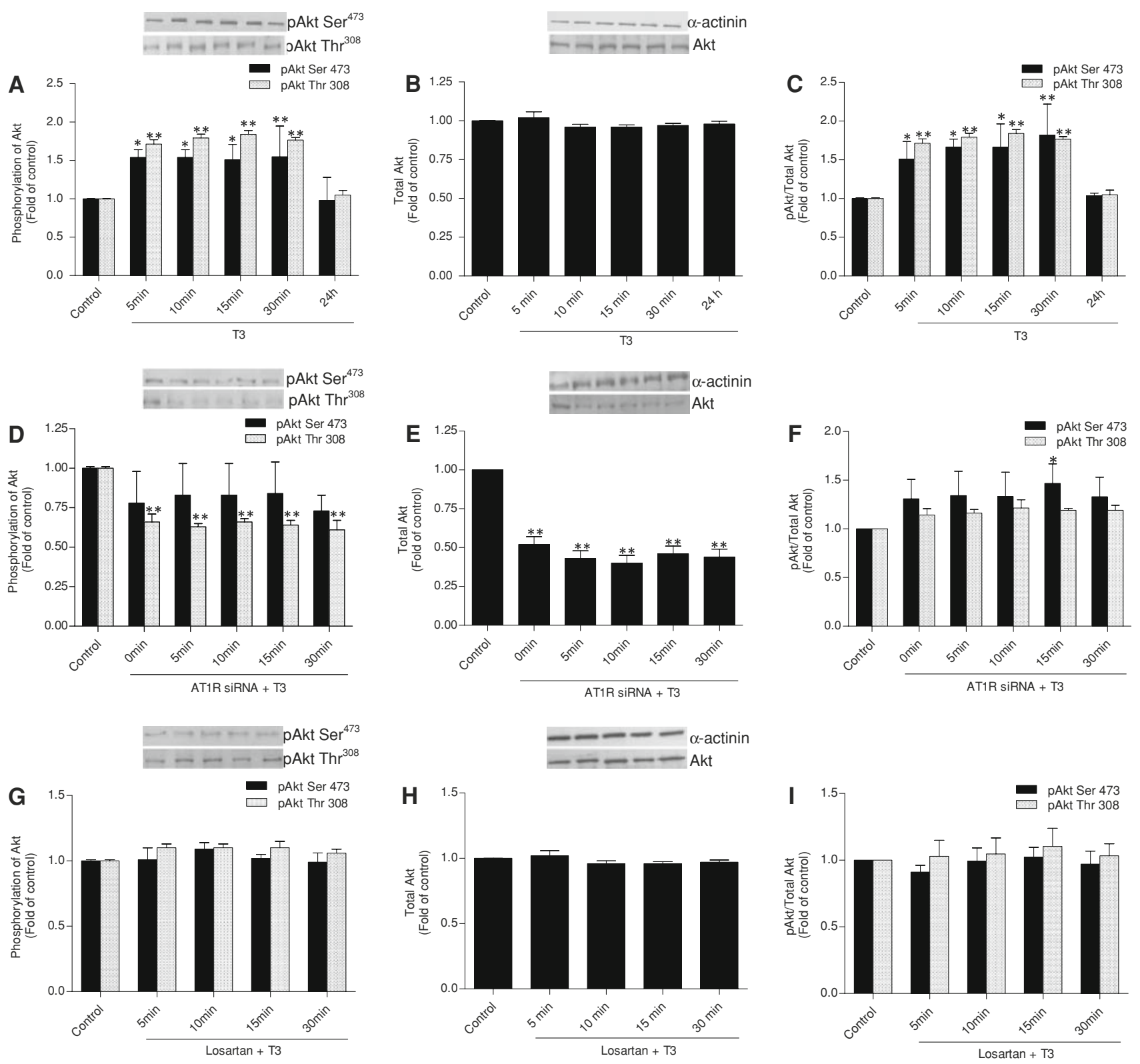

Fig. 3 Phosphorylation of Akt at $\operatorname{Ser}^{473}$ and at $\mathrm{Thr}^{308}$ (a), total Akt (b) and phosphorylation of Akt at $\mathrm{Ser}^{473}$ and at $\mathrm{Thr}^{308}$ level/total Akt level ratio (c) in cultured cardiomyocytes treated with serum-free medium containing $10 \mathrm{nM}$ of $\mathrm{T}_{3}$ for $5,10,15,30 \mathrm{~min}$ or $24 \mathrm{~h}$, or only serum-free medium in control cells, evaluated by Western blotting. Phosphorylation of Akt at $\mathrm{Ser}^{473}$ and at $\mathrm{Thr}^{308}$ (d), total Akt (e) and phosphorylation of Akt at $\mathrm{Ser}^{473}$ and at $\mathrm{Thr}^{308}$ level/total Akt level ratio (f) in cells transfected with $50 \mathrm{nM}$ of $\mathrm{AT}_{1} \mathrm{R}$ siRNA for $72 \mathrm{~h}$, treated with $10 \mathrm{nM}$ of $\mathrm{T}_{3}$ for $5,10,15$ or $30 \mathrm{~min}$ in serum-free

medium, or only serum-free medium in control cells. Phosphorylation of Akt at $\mathrm{Ser}^{473}$ and at $\mathrm{Thr}^{308}$ (g), total Akt (h) and phosphorylation of Akt at $\mathrm{Ser}^{473}$ and $\mathrm{Thr}^{308}$ level/total Akt level ratio (i) in cells treated with serum-free medium containing $1 \mu \mathrm{M}$ of Losartan (Los) for $30 \mathrm{~min}$, treated with $10 \mathrm{nM}$ of $\mathrm{T}_{3}$ for $5,10,15$ or $30 \mathrm{~min}$, or serumfree medium in control cells. $\alpha$-Actinin protein expression was used for normalization. Values represent fold of induction in relation to control cells. $* P<0.05$ vs. control; $* * P<0.01$ vs. control. Number $(N)$ represents the different cardiomyocyte preparations $(n=4)$

mTOR signaling pathway. The cardiomyocytes were pretreated with LY294002 $(10 \mu \mathrm{M})$ and Wortmannin $(200 \mathrm{nM})$ for $30 \mathrm{~min}$, which are specific PI3K inhibitors, and then were stimulated with $\mathrm{T}_{3}(10 \mathrm{nM})$ for $5,10,15$ and $30 \mathrm{~min}$. The use of both PI $3 \mathrm{~K}$ inhibitors totally prevented the $\mathrm{T}_{3}$-induced increase in the phosphorylation levels of
Akt at $\operatorname{Ser}^{473}$ (Fig. 6a, b). Similarly, phosphorylation of GSK3- $\beta$ at Ser $^{9}$ induced by $\mathrm{T}_{3}$ treatment was completely blocked using PI3K inhibitors (Fig. 6c, d). In the same way, the use of PI3K inhibitors totally prevented the $\mathrm{T}_{3}$-induced increase in the phosphorylation levels of mTOR at $\operatorname{Ser}^{2448}$ (Fig. 6e, f). 

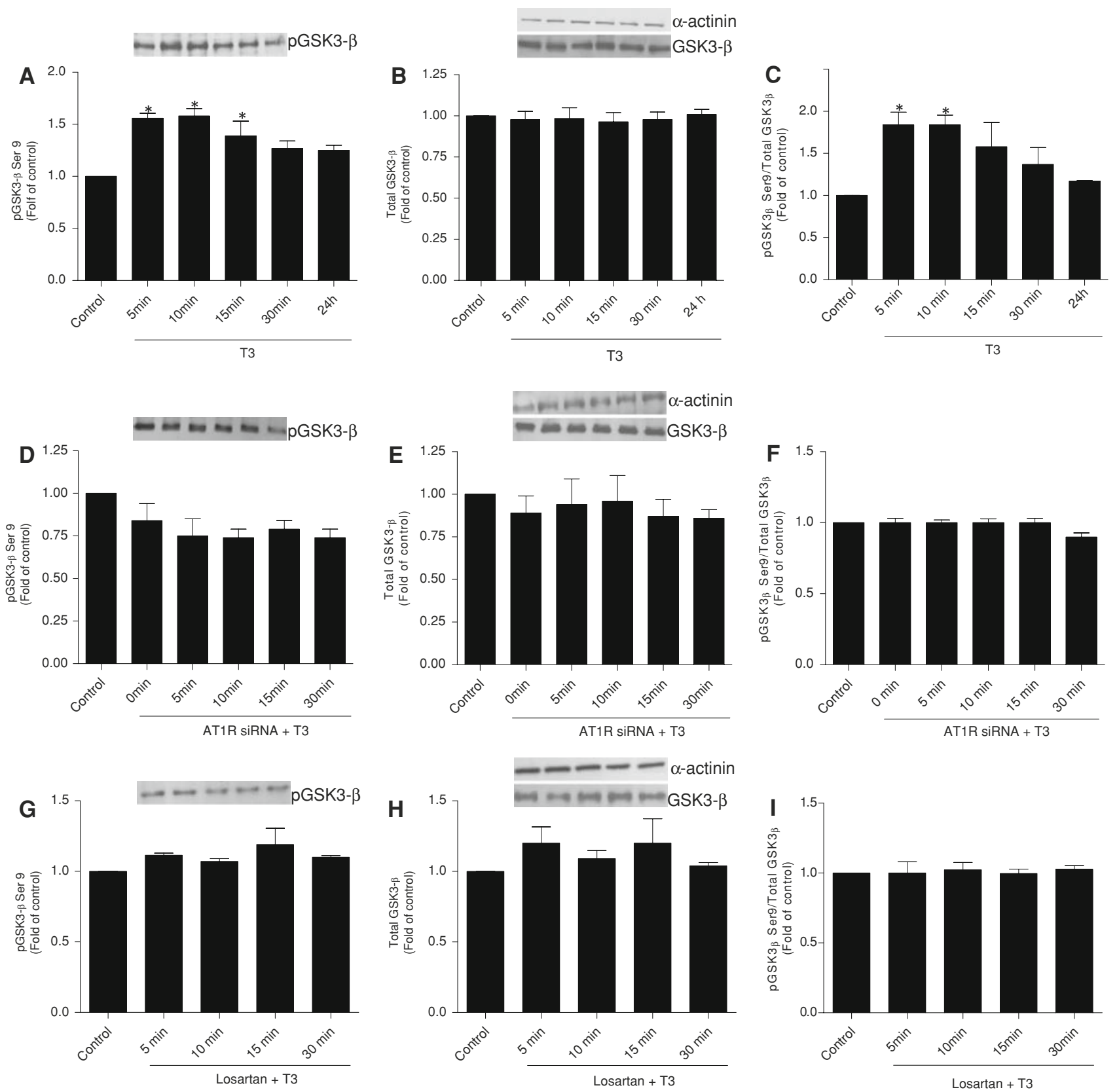

Fig. 4 Phosphorylation of GSK3- $\beta$ at $\operatorname{Ser}^{9}$ (a), total GSK3- $\beta$ (b) and phosphorylation of GSK3- $\beta$ at Ser $^{9}$ level/total GSK3- $\beta$ level ratio (c) in cultured cardiomyocytes treated with serum-free medium containing $10 \mathrm{nM}$ of $\mathrm{T}_{3}$ for $5,10,15,30 \mathrm{~min}$ or $24 \mathrm{~h}$, or only serum-free medium in control cells, evaluated by Western blotting. Phosphorylation of GSK3- $\beta \operatorname{Ser}^{9}$ (d), total GSK3- $\beta$ (e) and phosphorylation of GSK3- $\beta$ at Ser $^{9}$ level/total GSK3- $\beta$ level ratio (f) in cells transfected with $50 \mathrm{nM}$ of $\mathrm{AT}_{1} \mathrm{R}$ siRNA in serum-free medium for $72 \mathrm{~h}$ treated with $10 \mathrm{nM}$ of $\mathrm{T}_{3}$ for $5,10,15$ or $30 \mathrm{~min}$, or only serum-free medium

$\mathrm{T}_{3}$ increases Ang I/II and $\mathrm{AT}_{1} \mathrm{R}$ expression in cardiomyocytes

Considering that the $\mathrm{AT}_{1} \mathrm{R}$ silencing or the $\mathrm{AT}_{1} \mathrm{R}$ blockade prevented the $\mathrm{T}_{3}$-induced cardiomyocyte hypertrophy as in control cells. Phosphorylation of GSK3- $\beta$ at $\operatorname{Ser}^{9}$ (g), total GSK3- $\beta$ (h) and phosphorylation of GSK3- $\beta$ at Ser ${ }^{9}$ level/total GSK3- $\beta$ level ratio (i) in cells treated with serum-free medium containing $1 \mu \mathrm{M}$ of Losartan (Los) for $30 \mathrm{~min}$, treated with $10 \mathrm{nM}$ of $\mathrm{T}_{3}$ for $5,10,15$ or $30 \mathrm{~min}$, or serum-free medium in control cells. $\alpha$-Actinin protein expression was used for normalization. Values represent fold of induction in relation to control cells. $* P<0.05$ vs. control. Number $(N)$ represents the different cardiomyocyte preparations $(n=4)$

well as the $\mathrm{T}_{3}$-induced activation of the Akt signaling pathway, we tested the hypothesis that $T_{3}$ treatment could promote an increase on local Ang I/II and $\mathrm{AT}_{1} \mathrm{R}$ expression, which could be partially contributing to the cardiomyocyte hypertrophy as well to the activation of the Akt 


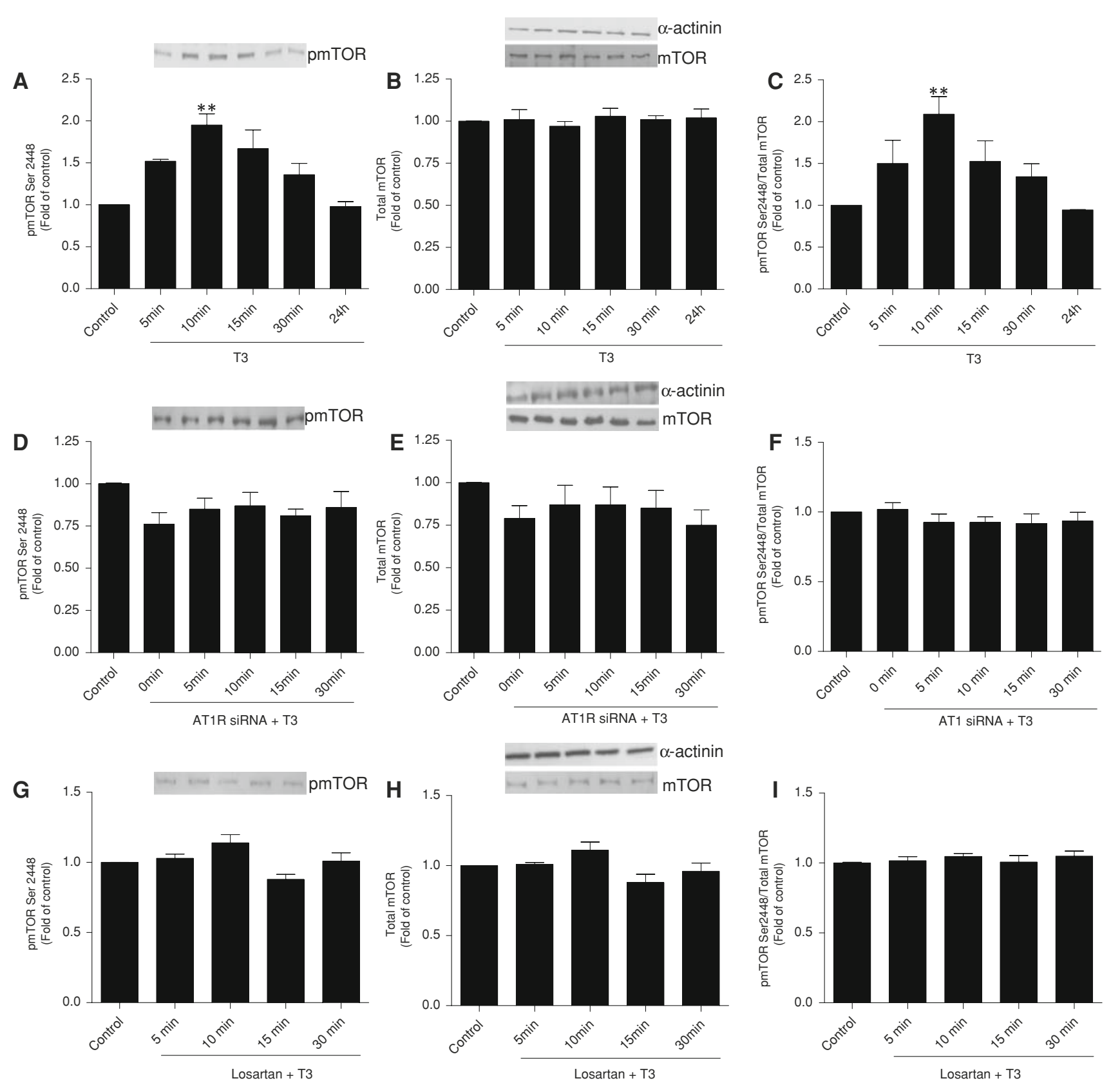

Fig. 5 Phosphorylation of mTOR at $\operatorname{Ser}^{2448}$ (a), total mTOR (b) and phosphorylation of mTOR at $\mathrm{Ser}^{2448}$ level/total mTOR level ratio (c) in cultured cardiomyocytes treated with serum-free medium containing $10 \mathrm{nM}$ of $\mathrm{T}_{3}$ for $5,10,15,30 \mathrm{~min}$ or $24 \mathrm{~h}$, or only serum-free medium in control cells, evaluated by Western blotting. Phosphorylation of mTOR at $\operatorname{Ser}^{2448}$ (d), total mTOR (e) and phosphorylation of mTOR at $\operatorname{Ser}^{2448}$ level/total mTOR level ratio (f) in cells transfected with $50 \mathrm{nM}$ of $\mathrm{AT}_{1} \mathrm{R}$ siRNA in serum-free medium for $72 \mathrm{~h}$ treated with $10 \mathrm{nM}$ of $\mathrm{T}_{3}$ for $5,10,15$ or $30 \mathrm{~min}$, or only serum-

signaling promoted by $\mathrm{T}_{3}$. Then, the cells were stimulated with $\mathrm{T}_{3}(10 \mathrm{nM})$ for $5,10,15$ and $30 \mathrm{~min}$ or $24 \mathrm{~h}$. Thereafter, Ang I/II and $\mathrm{AT}_{1} \mathrm{R}$ protein expression were determined using Western blot and the $\mathrm{AT}_{1} \mathrm{R}$ gene expression was evaluated by real-time RT-PCR. Increased free medium in control cells. Phosphorylation of mTOR at $\operatorname{Ser}^{2448}(\mathbf{g})$, total mTOR (h) and phosphorylation of mTOR at $\operatorname{Ser}^{2448}$ level/total mTOR level ratio (i) in cells treated with serum-free medium containing $1 \mu \mathrm{M}$ of Losartan (Los) for 30 min, treated with $10 \mathrm{nM}$ of $\mathrm{T}_{3}$ for $5,10,15$ or $30 \mathrm{~min}$, or serum-free medium in control cells. $\alpha$-Actinin protein expression was used for normalization. Values represent fold of induction in relation to control cells. $* * P<0.01$ vs. control. Number $(N)$ represents the different cardiomyocyte preparations $(n=4)$

levels of Ang I/II were observed after $10 \mathrm{~min}$ of stimulation by $\mathrm{T}_{3}(120 \%, P<0.05$ vs. control), which were maintained through $30 \mathrm{~min}(118 \%, P<0.01$ vs. control) of $\mathrm{T}_{3}$ treatment (Fig. 7a). Similarly, $\mathrm{T}_{3}$ promoted significantly higher expression of Ang I/II levels after $24 \mathrm{~h}$ of 

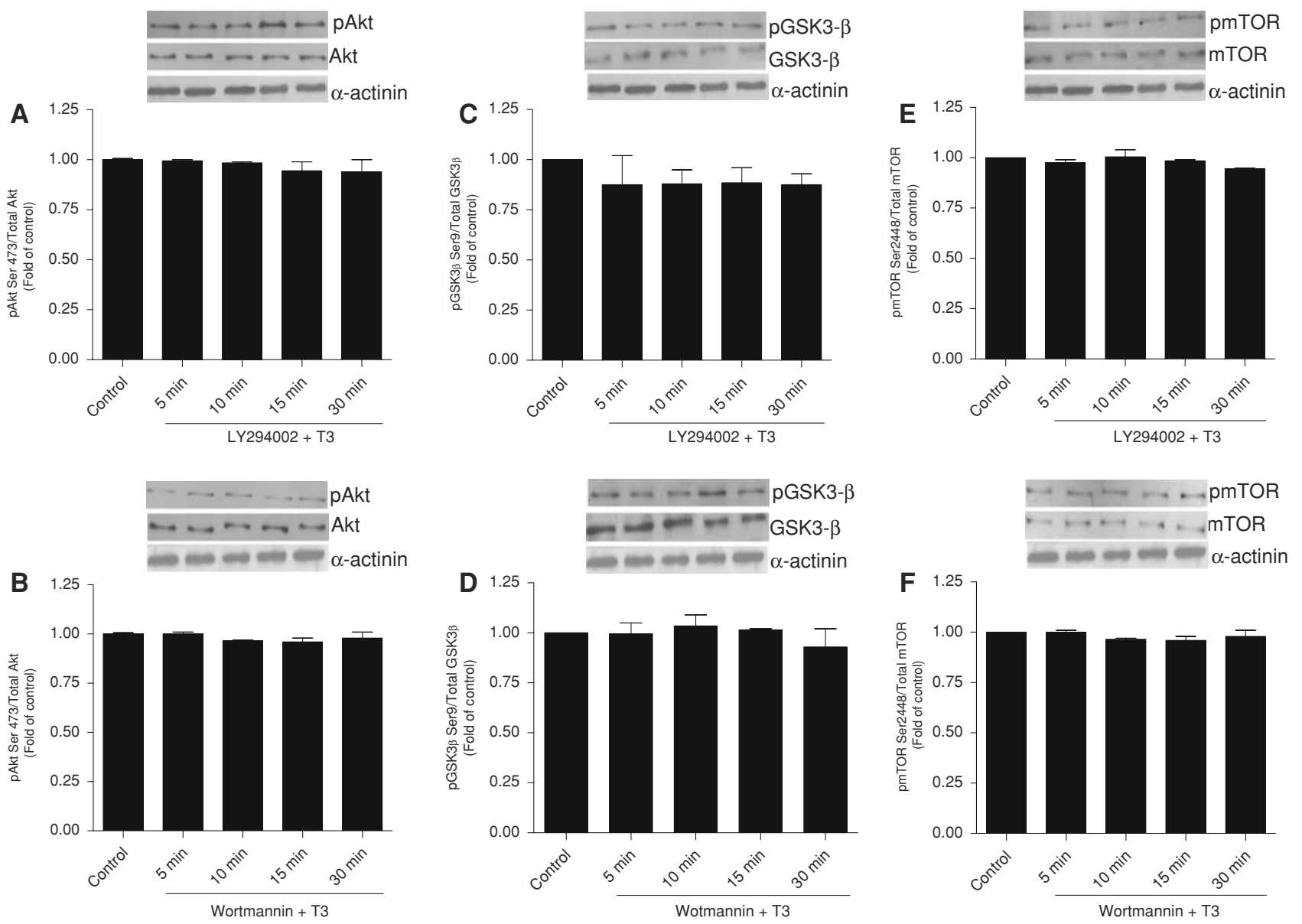

Fig. 6 Phosphorylation of Akt at $\mathrm{Ser}^{473}$ level/total Akt level ratio (a, b), phosphorylation of GSK3- $\beta$ at Ser $^{9}$ level/total GSK3- $\beta$ level ratio $(\mathbf{c}, \mathbf{d})$ and phosphorylation of mTOR at $\mathrm{Ser}^{2448}$ level/total mTOR level ratio in cells treated with serum-free medium containing $10 \mu \mathrm{M}$ of LY294002 (a, c, e) or $200 \mathrm{nM}$ of Wortmannin (b, d, f) for $30 \mathrm{~min}$,

treatment (165\%, $P<0.01$ vs. control). In addition, the $\mathrm{AT}_{1} \mathrm{R}$ mRNA (Fig. 7b) and protein expression levels (Fig. 7c) were significantly higher after treatment with $T_{3}$ for 5 min (2-fold approximately, $P<0.05$ vs. control) and maintained through $30 \mathrm{~min}$ (2-fold approximately, $P<0.01$ vs. control) of $\mathrm{T}_{3}$ stimulation. In contrast, the $\mathrm{AT}_{1} \mathrm{R}$ gene and protein expression were not changed after $24 \mathrm{~h}$ of treatment with $\mathrm{T}_{3}$. Figure 8 shows a proposed model for the $\mathrm{AT}_{1} \mathrm{R}$ participation in $\mathrm{T}_{3}$-induced cardiomyocyte hypertrophy as well as in the $\mathrm{T}_{3}$-induced activation of Akt/GSK3- $\beta /$ mTOR signaling pathway.

\section{Discussion}

The present study was designed to determine the potential roles of $\mathrm{AT}_{1} \mathrm{R}$ in cardiomyocyte hypertrophy induced by $\mathrm{T}_{3}$ as well as to the activation of the Akt/GSK-3 $\beta / \mathrm{mTOR}$ signaling promoted by $\mathrm{T}_{3}$. Although it is widely described treated with $10 \mathrm{nM}$ of $\mathrm{T}_{3}$ for $5,10,15$ and $30 \mathrm{~min}$, or only serum-free medium in control cells, evaluated by Western blotting. $\alpha$-Actinin protein expression was used for normalization. Values represent fold of induction in relation to control cells. Number $(N)$ represents the different cardiomyocyte preparations $(n=3)$

that $\mathrm{TH}$ activates growth in cardiomyocytes in vitro and in vivo [30,34], it has been shown that the RAS is activated in hyperthyroidism and is involved in the development of cardiac hypertrophy since Ang II acts as a potent myocyte growth factor $[3,21]$. The $\mathrm{AT}_{1} \mathrm{R}$ has been implicated as the mediator of Ang II-induced cardiac hypertrophy [51]. Then, we hypothesize that, at least in part, the $\mathrm{AT}_{1} \mathrm{R}$ could participate as a mediator of hypertrophic response promoted by $\mathrm{TH}$ in cardiomyocytes. In order to evaluate the exact role of $\mathrm{AT}_{1} \mathrm{R}$ in $\mathrm{T}_{3}$-induced cardiomyocyte hypertrophy in vitro as well as in $\mathrm{T}_{3}$-induced activation of the Akt/GSK-3 $\beta / \mathrm{mTOR}$ signaling pathway, we used two different strategies: an $\mathrm{AT}_{1} \mathrm{R}$ siRNA to selectively silence the $\mathrm{AT}_{1} \mathrm{R}$ in cardiomyocyte cultures and the $\mathrm{AT}_{1} \mathrm{R}$ pharmacologic blockade using Losartan.

Herein, we showed for the first time that $\mathrm{AT}_{1} \mathrm{R}$ is determinant in $\mathrm{T}_{3}$-induced cardiomyocyte hypertrophy, as assessed by the analysis of the gene expression of two cardiac hypertrophy markers as well as by the evaluation of 

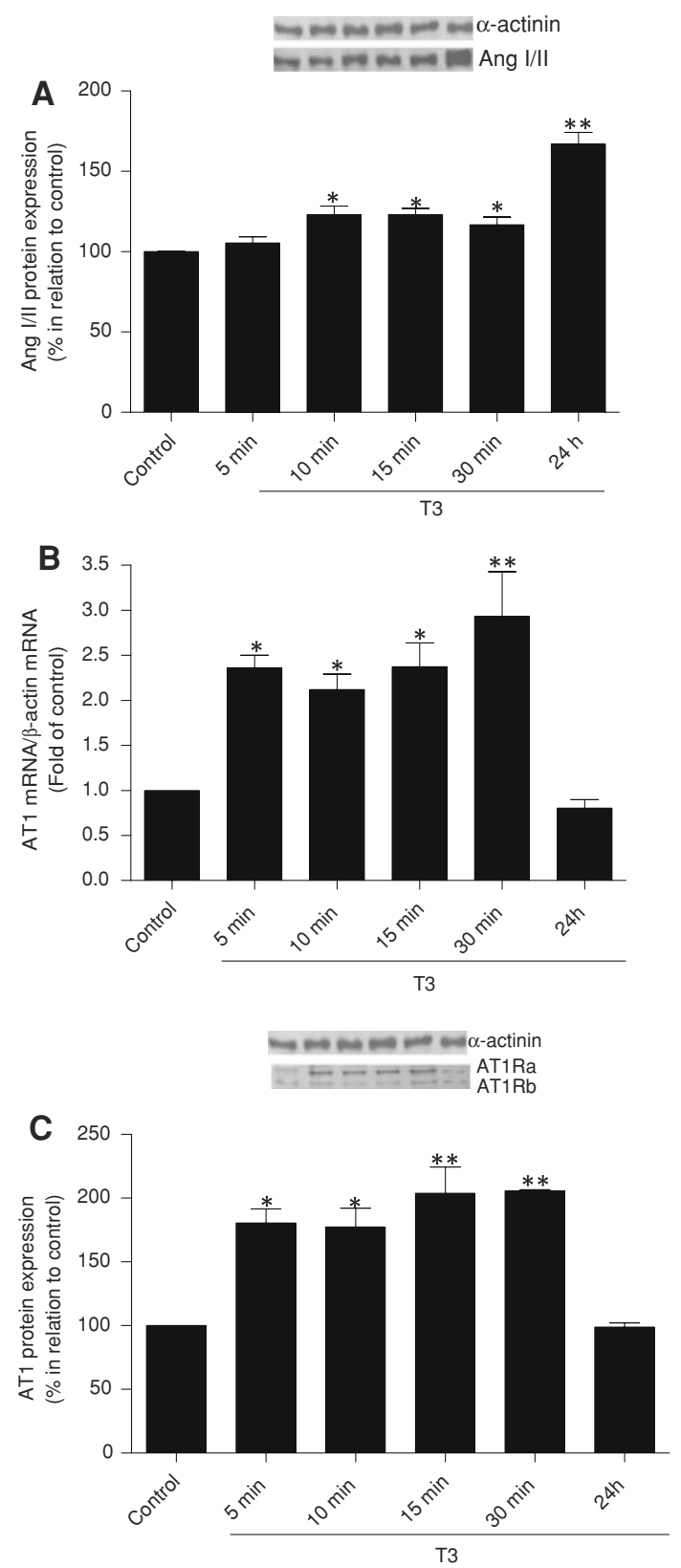

Fig. 7 Ang I/II levels (a) in cultured cardiomyocytes evaluated by Western blotting. $\mathrm{AT}_{1} \mathrm{R}$ mRNA (b) and protein expression in cultured cardiomyocytes (c) evaluated, respectively, by real-time RT-PCR and Western blotting. The cells were treated with serum-free medium containing $10 \mathrm{nM}$ of $\mathrm{T}_{3}$ for $5,10,15,30 \mathrm{~min}$ or $24 \mathrm{~h}$, or only serumfree medium in control cells. $\alpha$-Actinin protein expression was used for normalization. Values represent the Ang I/II level/ $\alpha$-actinin level (a), $\mathrm{AT}_{1} \mathrm{R}$ mRNA$/ \beta$-actin mRNA (b) and $\mathrm{AT}_{1} \mathrm{R}$ level $/ \alpha$-actinin level (c) ratio. $* P<0.05$ vs. control; $* * P<0.01$ vs. control. Number $(N)$ represents the different cardiomyocyte preparations $(n=3)$

the protein synthesis. The $A_{1} R$ silencing, or the $A_{1} R$ blockade, completely abolished the development of $\mathrm{T}_{3^{-}}$ induced cardiomyocyte hypertrophy, implicating the $\mathrm{AT}_{1} \mathrm{R}$ as a key mediator of the trophic effect that $T_{3}$ has on isolated cardiomyocytes. In fact, even in the absence of $\mathrm{T}_{3}$ treatment, the $\mathrm{AT}_{1} \mathrm{R}$ silencing reduced the $\mathrm{ANF}$ and skeletal $\alpha$-actin gene expression which may have occurred due to different possible mechanisms. Previous studies demonstrated that Ang II, via its $\mathrm{AT}_{1} \mathrm{R}$, activates the ANF promoter through JAK/STAT and PKC/GATA-4 [62]. In addition, PI3K/Akt signaling pathway was already demonstrated to modulate the increase on ANF gene expression in cardiomyocytes [9]. Besides, skeletal $\alpha$-actin gene expression is modulated by AP-1 transcription factors and serum response factor in cardiomyocytes [50], which are also activated by Ang II, via its $\mathrm{AT}_{1} \mathrm{R}[23,63]$. Taking this into consideration, it is possible that the $\mathrm{AT}_{1} \mathrm{R}$ silencing results in changes of several transcriptional factors that are crucial to the activation of the ANF and skeletal $\alpha$-actin, which could explain the reduction of both cardiac hypertrophy markers. Moreover, these results suggest that $\mathrm{AT}_{1} \mathrm{R}$ presents an important role, in basal conditions, to the maintenance of ANF and skeletal $\alpha$-actin mRNA levels in cardiomyocytes.

Although the effects of $\mathrm{THs}$ that are mediated by the modulation of gene expression are known to occur with a time lag of hours or even days, research that has been carried out mainly in the past decade has identified other responses to $\mathrm{TH}$ that are more rapid and take place in seconds or minutes. These responses follow non-genomic pathways, and they are not rare. In this context, studies have focused on the rapid effects of $T_{3}$ on cultured cardiomyocytes and demonstrated that $T_{3}$ rapidly increased PI3K activity, resulting in activation of its downstream effectors as one of the mechanisms by which TH regulates physiological cardiac growth [30]. However, the exact mechanisms by which the Akt/GSK-3 $\beta /$ mTOR signaling pathway is activated remain unclear. In the present study, we demonstrated, for the first time, a rapid $\mathrm{T}_{3}$-induced increase in the phosphorylation levels of GSK3- $\beta$ in isolated cardiomyocytes, which might also contribute to the hypertrophic effect that $T_{3}$ presents on these cells. Some in vitro studies indicate that distinct pathways are operational during the early course of hypertrophic growth and converge to activate mTOR resulting in the translational activation of $5^{\prime}$-terminal oligopyrimidine mRNA [58]. It is curious that in the present study we have observed different times related to Akt activation, phosphorylation/inactivation of GSK3- $\beta$ and mTOR activation. However, it is important to consider that the phosphorylation of GSK3- $\beta$ may be independent of Akt [46] and thus other proteins may be involved in this process. Similarly, the Akt activation is not the unique mechanism by which mTOR is activated [43, 44]. In this work, a rapid activation of the Akt/GSK3- $\beta / \mathrm{mTOR}$ signaling induced by $\mathrm{T}_{3}$ was observed, which was not maintained after $24 \mathrm{~h}$ of treatment. Taking this into account, it is important to consider that the Akt signaling activation is counteracted by the 


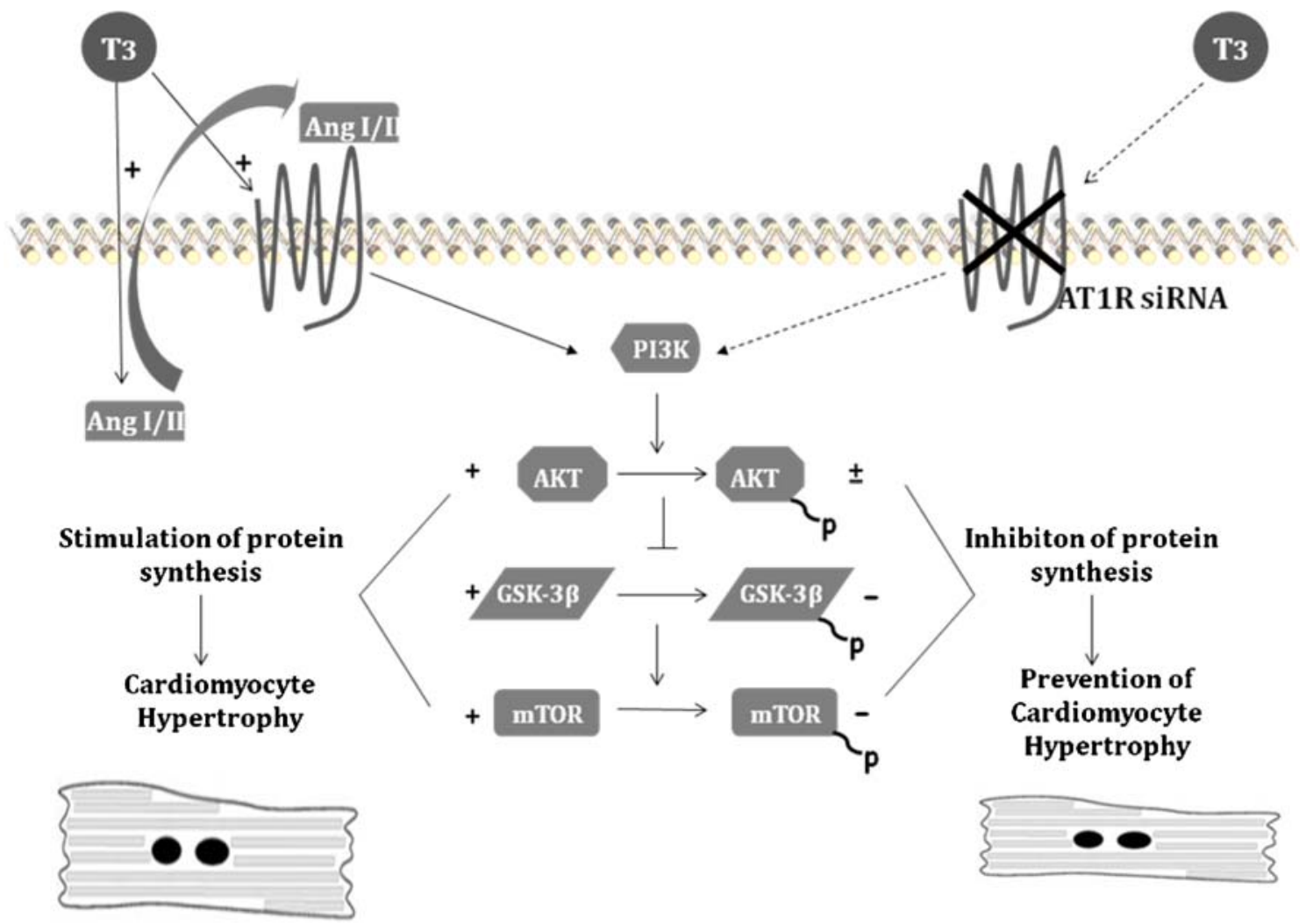

Fig. 8 Proposed model for the $A T_{1} R$ participation in $T_{3}$-induced cardiomyocyte hypertrophy as well as in the activation of Akt/GSK3$\beta /$ mTOR signaling pathway. $\mathrm{T}_{3}$ stimulates Ang $\mathrm{I} / \mathrm{II}$ and $\mathrm{AT}_{1} \mathrm{R}$ expression in cardiomyocytes. The $\mathrm{AT}_{1} \mathrm{R}$ mediates the $\mathrm{T}_{3}$-induced activation of the Akt/GSK3- $\beta /$ mTOR signaling pathway, culminating in the cardiomyocyte hypertrophy (left side of the model). However, the $\mathrm{AT}_{1} \mathrm{R}$ silencing or the $\mathrm{AT}_{1} \mathrm{R}$ blockade attenuates or prevents the

action of phosphatases, such as PTEN (phosphatase and tensin homolog deleted on chromosome 10) [42], which could be contributing to the rapid $\mathrm{T}_{3}$-induced activation of the Akt/GSK3- $\beta /$ mTOR signaling. However, future studies are needed to evaluate these questions.

Herein, we also observed that the rapid effect exerted by $\mathrm{T}_{3}$ in the activation of the Akt/GSK3- $\beta / \mathrm{mTOR}$ signaling pathway in cardiomyocytes cultures was mediated by PI3K, since the inhibition of PI3K completely blockades the activation of this signaling pathway promoted by $\mathrm{T}_{3}$. These results are supported by data previously published, which demonstrated that the interaction between the cytosolic TH receptor (TR) $\alpha 1$ and the $\mathrm{p} 85 \alpha$ subunit of PI3K mediated the $T_{3}$-induced activation of PI3K [30]. In addition, our data showed that $\mathrm{AT}_{1} \mathrm{R}$ is a critical mediator of the rapid effect that $\mathrm{T}_{3}$ has on the activation of the Akt/ GSK-3 $\beta /$ mTOR signaling pathway in cardiomyocyte cultures, as evidenced by the fact that the use of $\mathrm{AT}_{1} \mathrm{R}$ siRNA or the $\mathrm{AT}_{1} \mathrm{R}$ blocker effectively attenuated or totally prevented the $\mathrm{T}_{3}$-induced activation of this signaling pathway. Thus, these results suggest that the $\mathrm{AT}_{1} \mathrm{R}$ is implicated as
$\mathrm{T}_{3}$-induced activation of the Akt/GSK3- $\beta /$ mTOR signaling pathway, culminating in the prevention of the cardiomyocyte hypertrophy (right side of the model). The sign (+) indicates activation, the sign $( \pm)$ indicates attenuation, while the sign $(-)$ indicates inactivation. The continuous arrow indicates $\mathrm{T}_{3}$-induced activation. The dashed arrow indicates prevention of $\mathrm{T}_{3}$-induced activation

one of the upstream activators of the Akt/GSK3- $\beta / \mathrm{mTOR}$ signaling pathway induced by $\mathrm{T}_{3}$ in cardiomyocytes. We surprisingly observed that the $\mathrm{AT}_{1} \mathrm{R}$ silencing, in addition to effect of preventing the elevation in the phosphorylation levels of Akt induced by $\mathrm{T}_{3}$, also induced a reduction of total Akt levels. The underlying mechanisms to account for this decrease in the total Akt levels are not clear. However, the findings obtained with Losartan, a pharmacological blocker of $\mathrm{AT}_{1} \mathrm{R}$, indicate that the decrease observed in the total Akt levels could occur due to silencing. It is possible that this method can influence the cytoskeleton, and an intact cytoskeleton seems to be important for the maintenance of Akt levels [22]. Moreover, considering that Aktinduced phosphorylation and subsequent phosphorylation/ inhibition of GSK3- $\beta$ are involved in ANF transcription [39], it is possible that the reduced total Akt levels may be contributing partially to the diminished mRNA levels of ANF and skeletal $\alpha$-actin observed in cells transfected with $\mathrm{AT}_{1} \mathrm{R}$ siRNA.

We recently demonstrated that cardiac $\mathrm{AT}_{1} \mathrm{R}$ is increased in rats submitted to experimental hypothyroidism. 
Similarly, cardiomyocytes cultures submitted to TH deprivation also presented elevated $\mathrm{AT}_{1} \mathrm{R}$ levels [7]; however, in that condition, they did not observed changes on the cardiac Ang II levels. In the present study, we investigated the possible modulation of Ang I/II and $\mathrm{AT}_{1} \mathrm{R}$ in cardiomyocytes treated with $\mathrm{T}_{3}$. Our data showed that $\mathrm{T}_{3}$ induced a rapid increase on Ang I/II levels in cardiomyocytes cultures, which was observed until $24 \mathrm{~h}$ of treatment. Then, the higher Ang I/II levels promoted by $\mathrm{T}_{3}$ may be partially responsible for the hypertrophic effect exerted by $\mathrm{T}_{3}$ on cardiomyocytes. Similarly, the $\mathrm{AT}_{1} \mathrm{R}$ gene and protein expression were increased rapidly by $\mathrm{T}_{3}$ treatment. However, $\mathrm{T}_{3}$ treatment was not able to modulate the $\mathrm{AT}_{1} \mathrm{R}$ expression after $24 \mathrm{~h}$ of treatment. Considering that the increased Ang I/II and $\mathrm{AT}_{1} \mathrm{R}$ expression occur in parallel with the activation of the Akt signaling, it is possible that Ang II, via its $\mathrm{AT}_{1} \mathrm{R}$, may be contributing to the $\mathrm{T}_{3}$-induced activation of this signaling pathway. This hypothesis is corroborated by the fact that the $\mathrm{AT}_{1} \mathrm{R}$ silencing or the $\mathrm{AT}_{1} \mathrm{R}$ blockade was able to attenuate or totally prevent the $\mathrm{T}_{3}$-induced activation of the Akt/GSK-3 $\beta / \mathrm{mTOR}$ signaling pathway. In addition, $\mathrm{T}_{3}$-induced cardiomyocyte hypertrophy was totally blocked by the $\mathrm{AT}_{1} \mathrm{R}$ silencing or the $\mathrm{AT}_{1} \mathrm{R}$ blockade, suggesting that even the $\mathrm{AT}_{1} \mathrm{R}$ expression has not been altered by $\mathrm{T}_{3}$ after $24 \mathrm{~h}$ of treatment, this receptor participates in $\mathrm{T}_{3}$-induced hypertrophy. The $\mathrm{AT}_{2} \mathrm{R}$ has a growth inhibitory effect [28, 57]. However, some recent studies have demonstrated that this receptor is required in some models of cardiac hypertrophy [11, 45]. However, whether $\mathrm{AT}_{2} \mathrm{R}$ may be contributing to the results obtained in the present study is unknown. In this way, some studies have been conducted in our group to answer these important questions.

In addition to the trophic effect promoted by the elevated $\mathrm{TH}$ levels, the long-term $\mathrm{TH}$ administration improves cardiac function after myocardial infarction in rats [48]. However, it is also important to consider that several studies have demonstrated that the type of cardiac hypertrophy induced by $\mathrm{TH}$ is absolutely dependent on duration and dose of treatment $[1,16,29]$. The TH-mediated cardiac hypertrophy in its initial phases is characterized as a physiological hypertrophy with increased SERCa2 and $\alpha$-myosin heavy chain ( $\alpha$-MHC) levels, decreased expression of $\beta$-myosin heavy chain ( $\beta$-MHC) and enhanced cardiac contractility. In contrast, Ang II-induced cardiac hypertrophy, characterized as a pathological cardiac hypertrophy, is associated with reduced SERCa2 and $\alpha$ MHC levels, increased $\beta$-MHC levels $[15,60]$, resulting in compromised myocardial contraction that inevitably leads to heart failure [18, 24, 34, 61]. Although the activation of Akt has been considered to be a common feature of the cardioprotective mechanisms, it has also been implicated in hypertrophy, fibrosis and cardiac dysfunction. Considering this, a clear separation between physiological and pathological hypertrophy is properly not feasible, and over time, a compensated physiological hypertrophy may result in a dilated cardiomyopathy or a pathological hypertrophy [17, 60].

Our results suggest that the $\mathrm{AT}_{1} \mathrm{R}$, which mediates the Ang II effects, a classical inductor of pathological hypertrophy, is critical to the $\mathrm{T}_{3}$-induced cardiomyocyte hypertrophy as well as to the $\mathrm{T}_{3}$-induced activation of the Akt signaling in cardiomyocytes cultures. Therefore, these findings suggest that the TH-induced cardiomyocyte hypertrophy may occur due to an interaction between pathways of physiological and pathological growth, since the $\mathrm{AT}_{1} \mathrm{R}$ silencing or the $\mathrm{AT}_{1} \mathrm{R}$ blocker prevented the $\mathrm{T}_{3}$-induced cardiomyocyte hypertrophy as well as the activation of the Akt signaling. This is an important and complex question, which requires necessarily further researches.

Limitation. In contrast to studies supporting the classical genomic mechanism of $\mathrm{TH}$, recent studies have suggested that $\mathrm{TH}$ also acts through a non-genomic mechanism by binding to plasma cytoplasmic membrane receptors that are able to activate signaling pathways $[5,13]$. To date, there have been no studies demonstrating interaction between the TR and the GPCR and demonstrating direct interaction between $\mathrm{T}_{3}$ and the GPCR. Further studies are needed in order to determine if the higher Ang I/II and $\mathrm{AT}_{1} \mathrm{R}$ levels promoted by $\mathrm{T}_{3}$ are responsible for mediating the critical role of $\mathrm{AT}_{1} \mathrm{R}$ in the $\mathrm{T}_{3}$-induced cardiomyocyte hypertrophy as well as in the $T_{3}$-induced activation of the Akt/GSK3- $\beta$ / mTOR signaling pathway. In addition, studies evaluating whether $\mathrm{AT}_{1} \mathrm{R}$ interacts with the TR or directly with $\mathrm{T}_{3}$ are also needed.

Considering that several clinical trials point out that there is an additional benefit for the prevention of cardiovascular diseases to treat patients with inhibitors of the RAS, such as $\mathrm{AT}_{1} \mathrm{R}$ blockers [40], and that this beneficial effect has been supposed to be the consequence of the inhibition of specific tissue effects of Ang II on cardiac remodeling [6], it is plausible that similar beneficial effect may be observed treating hyperthyroid patients with $\mathrm{AT}_{1} \mathrm{R}$ blockers. However, futures studies are needed to answer this question.

In summary, the present study has identified that $\mathrm{AT}_{1} \mathrm{R}$ acts as a critical mediator in $\mathrm{T}_{3}$-induced cardiomyocyte hypertrophy. In addition, we have shown that $A T_{1} R$ is fundamental to the $T_{3}$-induced activation of the Akt/GSK$3 \beta / \mathrm{mTOR}$ signaling pathway in cultured cardiomyocytes. It is plausible that the activation of these kinases, mediated by $\mathrm{AT}_{1} \mathrm{R}$, is directly involved in $\mathrm{T}_{3}$-induced cardiomyocyte hypertrophy, since the $\mathrm{AT}_{1} \mathrm{R}$ silencing or $\mathrm{AT}_{1} \mathrm{R}$ blockade abolished the $\mathrm{T}_{3}$-induced activation of Akt/GSK-3 $\beta / \mathrm{mTOR}$ signaling pathway as well as the development of $\mathrm{T}_{3}$-induced cardiomyocyte hypertrophy. Moreover, it is also 
plausible that the higher Ang I/II levels and $\mathrm{AT}_{1} \mathrm{R}$ could be mediating the $\mathrm{T}_{3}$ effect on the activation of Akt/GSK-3 $\beta$ / mTOR signaling pathway as well as in the cardiomyocyte hypertrophy, demonstrating a new mechanism by which $T_{3}$ promotes growth in cardiomyocytes.

\section{Materials and methods}

Primary cardiomyocyte cultures

All animal experimentation and protocols were conducted in accordance with the Ethical Principles in Animal Research, set forth by Brazilian College of Animal Experimentation, and were approved by the Biomedical Sciences Institute of the University of São Paulo Ethics Committee. Primary cultures of neonatal rat ventricular cardiomyocytes were prepared by enzymatic disaggregation from 1- to 3-day-old Wistar rats, as described previously by us [4]. Cells were seeded at approximately $2 \times 10^{5}$ cells/well into six-well plates and maintained in Dulbecco's modified Eagle's medium (DMEM) containing 5\% newborn calf serum (Invitrogen, Carlsbad, CA) and $10 \%$ horse serum (Invitrogen) in a humidified incubator $\left(5 \% \mathrm{CO}_{2}, 37^{\circ} \mathrm{C}\right)$. After $48 \mathrm{~h}$, the cells were maintained for $24 \mathrm{~h}$ in DMEM containing NCS $0.5 \%$ before the treatments.

\section{Small interfering RNA assays}

All protocols of siRNA transfection of cardiomyocyte cultures using a transfection mediator (Lipofectamine $2000^{\mathrm{TM}}$; Invitrogen) were performed following the manufacturer instructions. To assess the non-specific effects provoked by transfection, we employed a negative control (50 nM, Stealth ${ }^{\mathrm{TM}}$ RNAi Negative Control Duplex; Invitrogen), which has a sequence that is not homologous to any known gene (scrambled RNAi). The control cells of all protocols of siRNA transfection were treated with serumfree medium containing the transfection mediator in order to avoid non-specific effects provoked by transfection.

Three different siRNA target sequences presenting different guanine and cytosine (GC) content were tested to determine the sequence best able to silence $\mathrm{AT}_{1} \mathrm{R}$. The high GC sequence (5'-AUA CGU UUC GGU AGA UGA CGG CUG G-3' and 5'-CCA GCC GUC AUC UAC CGA AAC GUA U-3'; $50 \mathrm{nM}$, Stealth ${ }^{\mathrm{TM}}$ RNA, $20 \mu \mathrm{M}$; Invitrogen) was selected.

Treatment of the cells:

At $56 \mathrm{~h}$ after transfection with siRNA, the cells were treated with serum-free medium in control cells or serum-free medium with $\mathrm{T}_{3}(10 \mathrm{nM}$, Sigma, St. Louis, MO) for 5, 10, 15,30 , and 1,440 $\min (24 \mathrm{~h})$. Non-transfected cells were treated with serum-free medium in control cells or serumfree medium with Losartan $(1 \mu \mathrm{M}$, Sigma) or with Wortmannin (200 nM, Cell Signaling) or with LY294002 (10 $\mu \mathrm{M}$, Cell Signaling) for $30 \mathrm{~min}$. The medium was discarded and the cells were treated with serum-free medium with Losartan, or with Wortmannin, or with LY294002 plus $\mathrm{T}_{3}$ for $5,10,15,30 \mathrm{~min}$ and $24 \mathrm{~h}$. Nontransfected cells were treated with serum-free medium in control cells or serum-free medium with $\mathrm{T}_{3}$ for $5,10,15$, $30 \mathrm{~min}$ and $24 \mathrm{~h}$.

Flow cytometry

To access the siRNA oligomer uptake into the cells, we used a fluorescent oligo $\left(50 \mathrm{nM}\right.$, Block-iT ${ }^{\mathrm{TM}}$ Fluorescent Oligo; Invitrogen), which has been employed as an indicator of transfection efficiency, as a positive control. The quantification of transfected cells was analyzed by flow cytometry (Personal Cell Analysis; Guava Technologies Inc., Hayward, CA).

\section{Real-time RT-PCR}

Total RNA was obtained using the Trizol reagent (Invitrogen), following the manufacturer instructions. For reverse transcriptase, we employed $1 \mu \mathrm{g}$ of total RNA using SuperScript II RNase H Reverse Transcriptase (Invitrogen). Real-time RT-PCR was performed using the SYBR Green PCR master mix (Invitrogen) according to manufacturer recommendations in a thermocycler (Corbett Research, Sydney, Australia). The following primer sequences were used:

- for $\mathrm{AT}_{1} \mathrm{R}$ : $5^{\prime}$-CAC TTT CCT GGA TGT GCT GA-3' and 5'-CCC AGA AAG CCG TAG AAC AG-3';

- for $\beta$-actin: $5^{\prime}$-AGT TCG CCA TGG ATG ACG AT-3' and $5^{\prime}$-AAG CCG GCC TTG CAC AT-3';

- for atrial natriuretic factor (ANF): $5^{\prime}$-AGT GCG GTG TCC AAC ACA G-3' and 5'-CTT CAT CGG TCT GCT CGC T-3';

- for skeletal $\alpha$-actin: $5^{\prime}$-CCT GCC ACA CGC CAT CAT- $3^{\prime}$ and 5'-GCT CGG TGA GGA TTT TCA TCA G-3'.

Samples were run in duplicate, and the real-time RT-PCR data were normalized to $\beta$-actin, since we have previously certified that variations in the TH levels were not able to modulate $\beta$-actin mRNA levels.

Protein synthesis

Protein synthesis was quantified on the basis of tritiated leucine incorporation [30]. Six hours before harvest, 
L- $\left[3,4,5-{ }^{3} \mathrm{H}\right]$ leucine $(5 \mu \mathrm{Ci} / \mathrm{ml})$ was added to the culture medium to measure incorporation into newly synthesized protein. Total cellular proteins were precipitated in ice-cold $10 \%$ trichloroacetic acid and collected by centrifugation $\left(14,000 \times \mathrm{g}, \quad 10 \mathrm{~min}, 4^{\circ} \mathrm{C}\right)$. The proteins pellets were washed twice by resuspension in cold $10 \%$ trichloroacetic acid and collected by centrifugation. The final pellets were dissolved in $0.2 \mathrm{~N} \mathrm{NaOH}$ by incubation at $60^{\circ} \mathrm{C}$ for $30 \mathrm{~min}$. The radioactivity was measured by liquid scintillation counting and normalized by the total cell number.

\section{Western blot analysis}

Cell lysates were obtained using digestion buffer $(90 \mathrm{mM}$ $\mathrm{KCl}, 10 \mathrm{mM}$ Hepes, $3 \mathrm{mM} \mathrm{MgCl}{ }^{2+}, 5 \mathrm{mM}$ ethylenediaminetetraacetic acid, $1 \%$ glycerol, $1 \mathrm{mM}$ dithiothreitol, $0.04 \%$ sodium dodecyl sulfate), and immunoblotting was performed as described previously [6]. The primary antibodies used were as follows: $\mathrm{AT}_{1} \mathrm{R}\left(\mathrm{AT}_{1} \mathrm{Ra}\right.$ and $\mathrm{AT}_{1} \mathrm{Rb}$, which were used for quantification of $\mathrm{AT}_{1} \mathrm{R}$ expression), $\mathrm{AT}_{2} \mathrm{R}$, Akt, pAkt Ser 473, pAkt Thr 308, GSK-3 $\beta$, Ang I/II and $\alpha$-actinin (Santa Cruz Biotechnology, Santa Cruz, CA), and pGSK-3 $\beta$ Ser 9, mTOR and pmTOR Ser 2448 (Cell Signaling Technology, Beverly, MA). Secondary peroxidase-conjugated anti-rabbit, anti-mouse and anti-goat immunoglobulin $\mathrm{G}$ antibodies (Amersham Biosciences, Piscataway, NJ) were also used. Signal detection was achieved with enhanced chemiluminescence detection reagents (Amersham Biosciences) and exposure to X-ray film. The protein bands were quantified using densitometry, and the band density was then calculated and expressed in percentage or fold of induction in relation to control. The samples were normalized to $\alpha$-actinin.

\section{Statistical analysis}

Data are presented as mean $\pm \mathrm{SD}$ and are expressed as percentage variation in relation to the control group or fold of induction in relation to control. Data were analyzed using one-way analysis of variance, followed by Tukey's post hoc test. Values of $P<0.05$ were considered statistically significant.

Acknowledgments The authors would like to thank Natássia Vieira and Dr. Mayana Zatz, both from the Neuromuscular Disease Research Center of the Institute of Biosciences of the University of São Paulo, for their assistance in performing the flow cytometry. This work was supported by Fundação de Amparo à Pesquisa do Estado de São Paulo (FAPESP, Foundation for the Support of Research in the State of São Paulo) and the Conselho Nacional de Desenvolvimento Científico e Tecnológico (CNPq, National Council for Scientific and Technological Development).

\section{References}

1. Araujo AS, Schenkel P, Enzveiler AT, Fernandes TR, Partata WA, Llesuy S, Ribeiro MF, Khaper N, Singal PK, Bello-Klein A (2008) The role of redox signaling in cardiac hypertrophy induced by experimental hyperthyroidism. J Mol Endocrinol 41:423-430

2. Bader M (2002) Role of the local renin-angiotensin system in cardiac damage: a minireview focussing on transgenic animal models. J Mol Cell Cardiol 34:1455-1462

3. Baker KM, Aceto JF (1990) Angiotensin II stimulation of protein synthesis and cell growth in chick heart cells. Am J Physiol 259:H610-H618

4. Barreto-Chaves ML, Heimann A, Krieger JE (2000) Stimulatory effect of dexamethasone on angiotensin-converting enzyme in neonatal rat cardiac myocytes. Braz J Med Biol Res 33:661-664

5. Bergh JJ, Lin HY, Lansing L, Mohamed SN, Davis FB, Mousa S, Davis PJ (2005) Integrin alphaVbeta3 contains a cell surface receptor site for thyroid hormone that is linked to activation of mitogen-activated protein kinase and induction of angiogenesis. Endocrinology 146:2864-2871

6. Billet S, Aguilar F, Baudry C, Clauser E (2008) Role of angiotensin II AT1 receptor activation in cardiovascular diseases. Kidney Int 74:1379-1384

7. Carneiro-Ramos MS, Diniz GP, Almeida J, Vieira RL, Pinheiro SV, Santos RA, Barreto-Chaves ML (2007) Cardiac angiotensin II type I and type II receptors are increased in rats submitted to experimental hypothyroidism. J Physiol 583:213-223

8. Carneiro-Ramos MS, Silva VB, Santos RA, Barreto-Chaves ML (2006) Tissue-specific modulation of angiotensin-converting enzyme (ACE) in hyperthyroidism. Peptides 27:2942-2949

9. Chandrasekar B, Mummidi S, Claycomb WC, Mestril R, Nemer $M$ (2005) Interleukin-18 is a pro-hypertrophic cytokine that acts through a phosphatidylinositol 3-kinase-phosphoinositide-dependent kinase-1-Akt-GATA4 signaling pathway in cardiomyocytes. J Biol Chem 280:4553-4567

10. Condorelli G, Drusco A, Stassi G, Bellacosa A, Roncarati R, Iaccarino G, Russo MA, Gu Y, Dalton N, Chung C, Latronico MV, Napoli C, Sadoshima J, Croce CM, Ross J (2002) Akt induces enhanced myocardial contractility and cell size in vivo in transgenic mice. Proc Natl Acad Sci USA 99:12333-12338

11. D'Amore A, Black MJ, Thomas WG (2005) The angiotensin II type 2 receptor causes constitutive growth of cardiomyocytes and does not antagonize angiotensin II type 1 receptor-mediated hypertrophy. Hypertension 46:1347-1354

12. Danser AH (1996) Local renin-angiotensin systems. Mol Cell Biochem 157:211-216

13. Davis PJ, Leonard JL, Davis FB (2008) Mechanisms of nongenomic actions of thyroid hormone. Front Neuroendocrinol 29:211-218

14. Dillmann WH (2002) Cellular action of thyroid hormone on the heart. Thyroid 12:447-452

15. Dillmann WH (2009) Cardiac hypertrophy and thyroid hormone signaling. Heart Fail Rev. doi:10.1007/s10741-008-9125-7

16. Diniz GP, Carneiro-Ramos MS, Barreto-Chaves ML (2007) Angiotensin type 1 (AT1) and type 2 (AT2) receptors mediate the increase in TGF-beta1 in thyroid hormone-induced cardiac hypertrophy. Pflugers Arch 454:75-81

17. Dorn GWII (2007) The fuzzy logic of physiological cardiac hypertrophy. Hypertension 49:962-970

18. Dorn GWII, Force T (2005) Protein kinase cascades in the regulation of cardiac hypertrophy. J Clin Invest 115:527-537

19. Dzau VJ (1988) Cardiac renin-angiotensin system. Molecular and functional aspects. Am J Med 84:22-27 
20. Eguchi S, Frank GD, Mifune M, Inagami T (2003) Metalloprotease-dependent ErbB ligand shedding in mediating EGFR transactivation and vascular remodelling. Biochem Soc Trans 31:1198-1202

21. Fischer P, Hilfiker-Kleiner D (2007) Survival pathways in hypertrophy and heart failure: the gp130-STAT3 axis. Basic Res Cardiol 102:279-297

22. Flusberg DA, Numaguchi Y, Ingber DE (2001) Cooperative control of Akt phosphorylation, bcl-2 expression, and apoptosis by cytoskeletal microfilaments and microtubules in capillary endothelial cells. Mol Biol Cell 12:3087-3094

23. Godeny MD, Sayeski PP (2006) ERK1/2 regulates ANG IIdependent cell proliferation via cytoplasmic activation of RSK2 and nuclear activation of elk1. Am J Physiol Cell Physiol 291:C1308-C1317

24. Golomb E, Abassi ZA, Cuda G, Stylianou M, Panchal VR, Trachewsky D, Keiser HR (1994) Angiotensin II maintains, but does not mediate, isoproterenol-induced cardiac hypertrophy in rats. Am J Physiol 267:H1496-H1506

25. Griendling KK, Ushio-Fukai M, Lassegue B, Alexander RW (1997) Angiotensin II signaling in vascular smooth muscle. New concepts. Hypertension 29:366-373

26. Gupta S, Das B, Sen S (2007) Cardiac hypertrophy: mechanisms and therapeutic opportunities. Antioxid Redox Signal 9:623-652

27. Higuchi S, Ohtsu H, Suzuki H, Shirai H, Frank GD, Eguchi S (2007) Angiotensin II signal transduction through the AT1 receptor: novel insights into mechanisms and pathophysiology. Clin Sci 112:417-428

28. Horiuchi M, Akishita M, Dzau VJ (1999) Recent progress in angiotensin II type 2 receptor research in the cardiovascular system. Hypertension 33:613-621

29. Hu LW, Benvenuti LA, Liberti EA, Carneiro-Ramos MS, Barreto-Chaves ML (2003) Thyroxine-induced cardiac hypertrophy: influence of adrenergic nervous system versus reninangiotensin system on myocyte remodeling. Am J Physiol Regul Integr Comp Physiol 285:R1473-R1480

30. Kenessey A, Ojamaa K (2006) Thyroid hormone stimulates protein synthesis in the cardiomyocyte by activating the Akt-mTOR and p70S6K pathways. J Biol Chem 281:20666-20672

31. Kobori H, Ichihara A, Miyashita Y, Hayashi M, Saruta T (1999) Local renin-angiotensin system contributes to hyperthyroidisminduced cardiac hypertrophy. J Endocrinol 160:43-47

32. Kobori H, Ichihara A, Suzuki H, Takenaka T, Miyashita Y, Hayashi M, Saruta T (1997) Role of the renin-angiotensin system in cardiac hypertrophy induced in rats by hyperthyroidism. Am J Physiol 273:H593-H599

33. Kuzman JA, Gerdes AM, Kobayashi S, Liang Q (2005) Thyroid hormone activates Akt and prevents serum starvation-induced cell death in neonatal rat cardiomyocytes. J Mol Cell Cardiol 39:841-844

34. Kuzman JA, Vogelsang KA, Thomas TA, Gerdes AM (2005) L-Thyroxine activates Akt signaling in the heart. J Mol Cell Cardiol 39:251-258

35. Ladenson PW, Bloch KD, Seidman JG (1988) Modulation of atrial natriuretic factor by thyroid hormone: messenger ribonucleic acid and peptide levels in hypothyroid, euthyroid, and hyperthyroid rat atria and ventricles. Endocrinology 123:652-657

36. Liang F, Webb P, Marimuthu A, Zhang S, Gardner DG (2003) Triiodothyronine increases brain natriuretic peptide (BNP) gene transcription and amplifies endothelin-dependent BNP gene transcription and hypertrophy in neonatal rat ventricular myocytes. J Biol Chem 278:15073-15083

37. Matsui T, Nagoshi T, Rosenzweig A (2003) Akt and PI 3-kinase signaling in cardiomyocyte hypertrophy and survival. Cell Cycle 2:220-223
38. Morgan HE, Baker KM (1991) Cardiac hypertrophy. Mechanical, neural, and endocrine dependence. Circulation 83:13-25

39. Morisco C, Zebrowski D, Condorelli G, Tsichlis P, Vatner SF, Sadoshima J (2000) The Akt-glycogen synthase kinase 3beta pathway regulates transcription of atrial natriuretic factor induced by beta-adrenergic receptor stimulation in cardiac myocytes. J Biol Chem 275:14466-14475

40. Moser M (2007) Hypertension treatment guidelines: is it time for an update? J Clin Hypertens 9:9-14

41. Okumura $\mathrm{H}$, Nagaya $\mathrm{N}$, Itoh $\mathrm{T}$, Okano I, Hino J, Mori $\mathrm{K}$, Tsukamoto Y, Ishibashi-Ueda H, Miwa S, Tambara K, Toyokuni S, Yutani C, Kangawa K (2004) Adrenomedullin infusion attenuates myocardial ischemia/reperfusion injury through the phosphatidylinositol 3-kinase/Akt-dependent pathway. Circulation 109:242-248

42. Oudit GY, Penninger JM (2009) Cardiac regulation by phosphoinositide 3-kinases and PTEN. Cardiovase Res 82:250-260

43. Oudit GY, Sun H, Kerfant BG, Crackower MA, Penninger JM, Backx PH (2004) The role of phosphoinositide-3 kinase and PTEN in cardiovascular physiology and disease. J Mol Cell Cardiol 37:449-471

44. Schmelzle T, Hall MN (2000) TOR, a central controller of cell growth. Cell 103:253-262

45. Senbonmatsu T, Ichihara S, Price E Jr, Gaffney FA, Inagami T (2000) Evidence for angiotensin II type 2 receptor-mediated cardiac myocyte enlargement during in vivo pressure overload. J Clin Invest 106:R25-R29

46. Sugden PH, Fuller SJ, Weiss SC, Clerk A (2008) Glycogen synthase kinase 3 (GSK3) in the heart: a point of integration in hypertrophic signalling and a therapeutic target? A critical analysis. Br J Pharmacol 153:S137-S153

47. Oudit GY, Sun H, Kerfant BG, Crackower MA, Penninger JM, Backx PH (2004) The role of phosphoinositide-3 kinase and PTEN in cardiovascular physiology and disease. J Mol Cell Cardiol 37:449-471

48. Pantos C, Mourouzis I, Markakis K, Tsagoulis N, Panagiotou M, Cokkinos DV (2008) Long-term thyroid hormone administration reshapes left ventricular chamber and improves cardiac function after myocardial infarction in rats. Basic Res Cardiol 103:308318

49. Pantos C, Mourouzis I, Xinaris C, Papadopoulou-Daifoti Z, Cokkinos D (2008) Thyroid hormone and "cardiac metamorphosis": potential therapeutic implications. Pharmacol Ther 118:277-294

50. Paradis P, MacLellan WR, Belaguli NS, Schwartz RJ, Schneider MD (1996) Serum response factor mediates AP-1-dependent induction of the skeletal alpha-actin promoter in ventricular myocytes. J Biol Chem 271:10827-10833

51. Sadoshima J, Izumo S (1993) Molecular characterization of angiotensin II-induced hypertrophy of cardiac myocytes and hyperplasia of cardiac fibroblasts. Critical role of the AT1 receptor subtype. Circ Res 73:413-423

52. Schaub MC, Hefti MA, Harder BA, Eppenberger HM (1997) Various hypertrophic stimuli induce distinct phenotypes in cardiomyocytes. J Mol Med 75:901-920

53. Schmidt-Ott UM, Ascheim DD (2006) Thyroid hormone and heart failure. Curr Heart Fail Rep 3:114-119

54. Skurk C, Izumiya Y, Maatz H, Razeghi P, Shiojima I, Sandri M, Sato K, Zeng L, Schiekofer S, Pimentel D, Lecker S, Taegtmeyer H, Goldberg AL, Walsh K (2005) The FOXO3a transcription factor regulates cardiac myocyte size downstream of AKT signaling. J Biol Chem 280:20814-20823

55. Suzuki H, Motley ED, Frank GD, Utsunomiya H, Eguchi S (2005) Recent progress in signal transduction research of the angiotensin II type-1 receptor: protein kinases, vascular 
dysfunction and structural requirement. Curr Med Chem Cardiovasc Hematol Agents 3:305-322

56. Takahashi T, Taniguchi T, Konishi H, Kikkawa U, Ishikawa Y, Yokoyama M (1999) Activation of Akt/protein kinase B after stimulation with angiotensin II in vascular smooth muscle cells. Am J Physiol 276:H1927-H1934

57. Tsuzuki S, Matoba T, Eguchi S, Inagami T (1996) Angiotensin II type 2 receptor inhibits cell proliferation and activates tyrosine phosphatase. Hypertension 28:916-918

58. Tuxworth WJ Jr, Shiraishi H, Moschella PC, Yamane K, McDermott PJ, Kuppuswamy D (2008) Translational activation of 5'-TOP mRNA in pressure overload myocardium. Basic Res Cardiol 103:41-53

59. Varagic J, Frohlich ED (2002) Local cardiac renin-angiotensin system: hypertension and cardiac failure. J Mol Cell Cardiol 34:1435-1442

60. Wakatsuki T, Schlessinger J, Elson EL (2004) The biochemical response of the heart to hypertension and exercise. Trends Biochem Sci 29:609-617
61. Wang B, Ouyang J, Xia Z (2006) Effects of triiodo-thyronine on angiotensin-induced cardiomyocyte hypertrophy: reversal of increased beta-myosin heavy chain gene expression. Can J Physiol Pharmacol 84:935-941

62. Wang J, Paradis P, Aries A, Komati H, Lefebvre C, Wang H, Nemer M (2005) Convergence of protein kinase C and JAKSTAT signaling on transcription factor GATA-4. Mol Cell Biol 25:9829-9844

63. Wu S, Gao J, Ohlemeyer C, Roos D, Niessen H, Kottgen E, Gessner R (2005) Activation of AP-1 through reactive oxygen species by angiotensin II in rat cardiomyocytes. Free Radic Biol Med 39:1601-1610

64. Yin G, Yan C, Berk BC (2003) Angiotensin II signaling pathways mediated by tyrosine kinases. Int J Biochem Cell Biol 35:780783 